Historic, archived document

Do not assume content reflects current scientific knowledge, policies, or practices. 



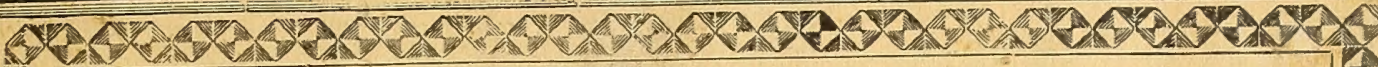

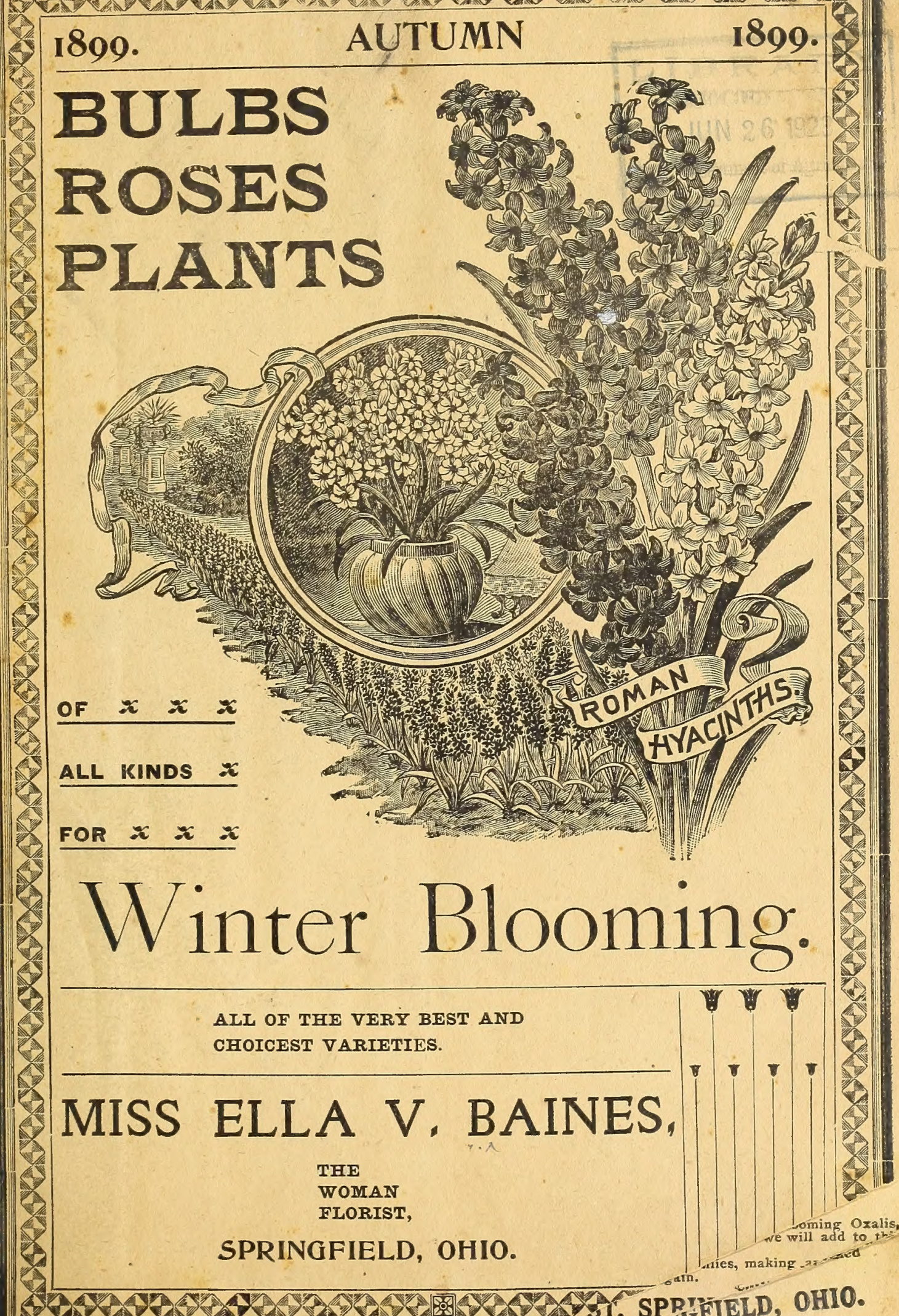


Miss Ella V. Baines, The Woman Florist, Springfield, Okio.

\section{HOLLAND, OR DUTCH BulBs.}

Holland produces all the Hyacinths, Tulips, etc., of the world, the climate and soil being better adapted to their culture than anywhere else that has been tried up to the present time. I wish to impress on my patrons the fact that

\section{IMPORT MY OWN BULBS}

direct from Holland, and I purchase the best varieties that money will buy; there. fore I can guarantee that my bulbs are the very best that can be found any. where. Giwe me a trial. I will not dis. appoint you.

I would advise the planting of all bulbs for Winter flowering in the common peach or grape basket (made from splits.)

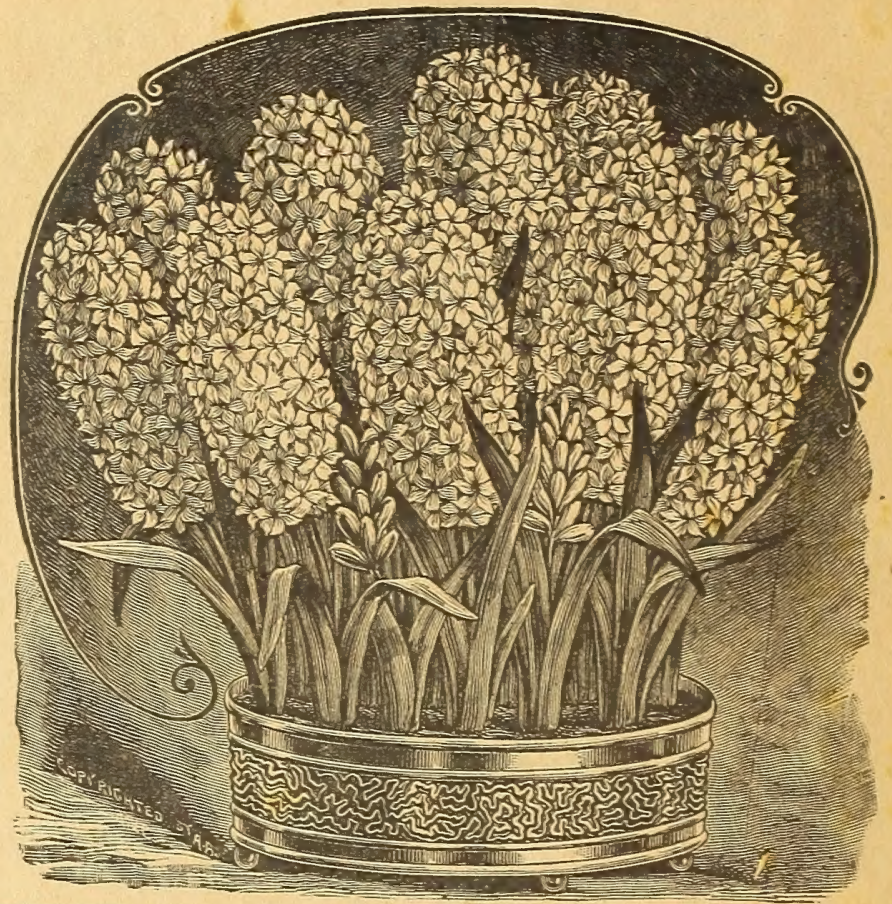

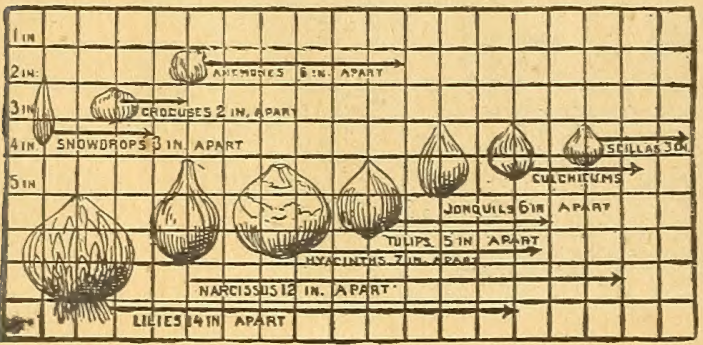

A DIAGRAM SHOWIN' DEPTH AND DISTANCE APART TO PLANT THE DIFFERENT VARIBTIES OF BULBS.
SINGLE HZACINTHS.

These can be procured at almost any grocery store. In these baskets Hyacinths, Narcissus, Tulips, Crocus, etc., can be flowered to the greatest perfection, and with the least trouble. I have found them much better for the purpose than pots. Try them and report success. I know you will be very much pleased with the results.

\section{ELEGANT LIST OF CHEAP SETS.}

PRICE

Set A-12 Ever-blooming Roses, twelve colors............50 cts Set B-12 Prize-winning Chrysanthemums, all different...50 cts Set $\mathbf{C}-10$ lovely Fuchsias, all different.................5 cts Set $\mathrm{D}-10$ elegant Double Geraniums.................... $5^{\circ} \mathrm{cts}$ Set $\mathbf{E}-10$ elegant Single Geraniums.................. 50 cts Set F-10 assorted Geraniums, double, single and scented. 50 cts Set G-10 choicest Double Hyacinths, all different colors. . 50 cts Set J-10 assorted $\mathbf{H y}$ acinths, double, single and Roman...50 cts Set $\mathrm{K}-10$ lovely Begonias, choicest kinds...............50 cts Set $\mathrm{L}-\mathbf{1 5}$ choicest kinds of Narcissus.................. 50 cts Set $M-\mathbf{2 5}$ Lilies of the Valley, exquisite............... 50 cts
Set N-12 magnificent Coleus, bright colors PRICE Set $0-4$ Chinese Sacred Lilies, or Joss Flowers.........50 cts Set $\mathrm{P}-60$ Crocus, in four kinds.........................50 cts Set $Q-25$ Parrot Tulips, all kinds.....................50 cts Set $\mathbf{R}-\mathbf{2 o}$ Double Tulips, all kinds.................... 50 cts Set S-25 Single Tulips, all kinds......................50 cts Set T-12 Vines and plants, suitable for vases and baskets $50 \mathrm{cts}$ Set $\mathrm{U}-\mathbf{4}$ choice Decorative Palms, elegant................50 cts Set V- 5 Dwarf Ever-blooming French Cannas.........50 cts Set W- 6 fragrant Carnation Pinks, ready to bloom.......50 cts Set $\mathbf{X}-\mathbf{8}$ choice Hibiscus, all colors ....................5 cts Set $\mathbf{Y}-4$ Begonia Rex, all different.... . ..............50 cts

NO TWO ALIKE IN THESE SETS.

-1 postpaid, safe arrival and satisfaction guaranteed. Order by the letter. 


\section{"HALF PRICE" COLLECTION OF}

SEVENTY-SIX CHOICE WINTER-BLOOMING BULBS FOR ONLY
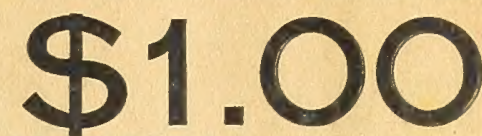

$\rightarrow \rightarrow$ SUITABLE FOR EITHER OUTDOOR OR HOUSE CULTURE.

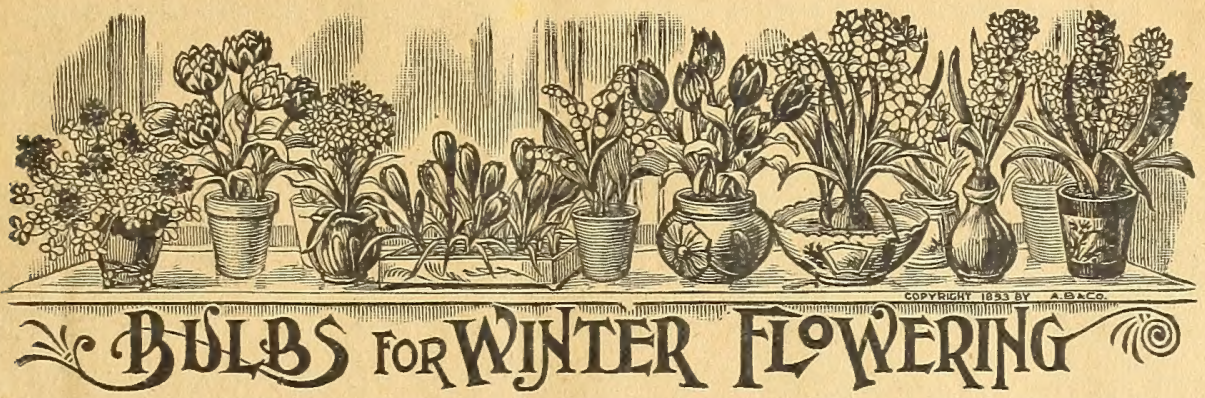

All the Bulbs offered in this collection, if planted with ordinary care, will bloom beautifully, and furnish flowere from Christmas until Easter. TRY THEM. IT WILL REPAY YOU WELL. In ordering, say "Half Price" Collection.

Six Hyacinths, four different colors.

Ten Tulips, six kinds.

Twenty Crocus, all colors.

pive Snowdrops.

pive Iris.

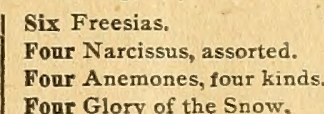

Fire Oxalis.
Three Alliums.
Three Tritilea,
and Beautiful Easter Lily.

SPECIAL OFFER.-For \$1.60 two "Ha1f Price" Collections; or for \$2.00 three Collections.

GET YOUR NEIGHBORS TO CLUB WITH YOU.
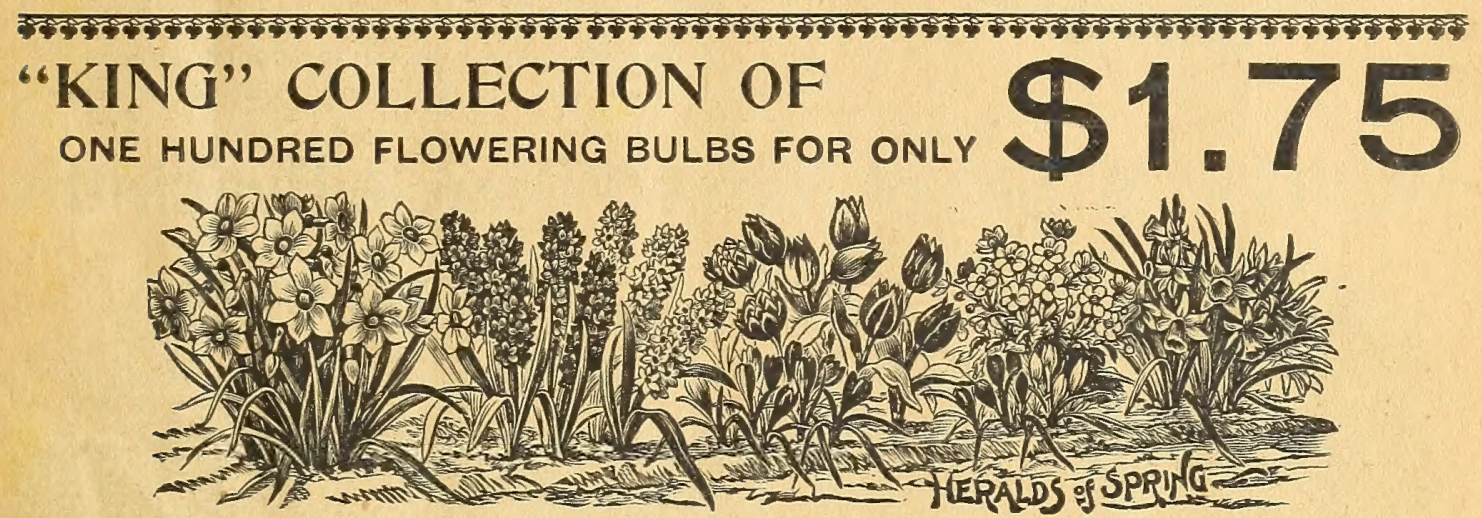

One Hundred Selected Bulbs for Indoor or Outdoor Fall Planting free by mail for otily $\$ 1.75$. One-half this Collection for \$1.00. In ordering, say "King" Collection.

Wight Fine Hyacinths, in eight fine sorts

of both Double and Single, all

Ton Single Tulips, assorted colors.

Ton Double Tulips, assorted colors.

Four Parrot Tulips, assorted
Six Sweet-scented Jonquils.
Fonr Beautiful Giant Snowdrops.

Five Beautiful Scillas; are really elegant.

Twenty Crocus, in four separate colors.

Four Narcissus Daffodils, assorted.

Four Glory of the Snow.
Fonr Ranunculus, all different.

Two Lily Harrisii, the beautifal Faste Lily.

Ten Beautiful Freesias, a charming flower. Ton Anemones, both Double and Single very elegant.

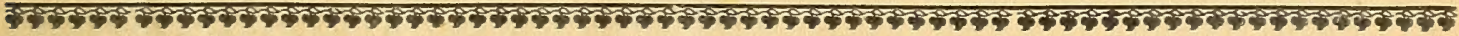
"QUEEN" COLLECTION OF 250 WINTER-FLOWERING BULBS FOR ONLY
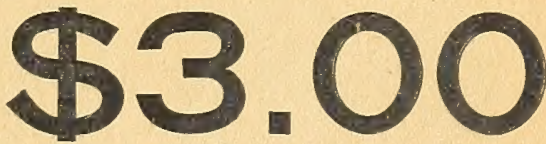

A GREAT BARGAIN.-Our "Queen" Collection of two hundred and fifty Winter-Flowering Bulbs for only $\$ 3.00$, by mail, prepaid. Please look over this collection of elegant Bulbs. If you can't use all of them, get a neighbor to send with you, and you can divide them. One-half this Collection for $\$ 1.50$. In ordering, say "Queen" Collection.

Sixteen Fine Hyacinths. both Double and Single, all colors.

Foar Roman Hyacinths, elegant for Winter.

Bght Grape Hyacinths, so lovely.

Four Beautiful Miniature Hyacinths.

Six Beautiful Feather Hyacinths.

Twelve Beautiful Single Tulips, all colors.

Twolvo Beautiful Double Tulips, all colors.

Six Beautiful Parrot Tnlips, all colors.

Bight Giant Snowdrops, very pretty.

Ton Scillas, elegant.

\author{
Sixteen Dou \\ Fifty Crocus, in four separate colors. \\ Six Narcissus Daffodils, assorted. \\ Ten Ranunculus, all different; very bright \\ and pretty. \\ Ten Elegant Freesias. \\ Six Jonquils, very fragrant. \\ Four Frittelarias, elegant for Winter. \\ Eight Iris, all beautiful kinds. \\ Eight Tritilea Uniflora, very elegant. \\ Four Lily Harrisii, or Gastern
}

Six Brodiea Coccinea, Floral Fire Crack. er, all rich colors.

Siz Sparaxis; try them and be pleased.

Six Ixias, a beautiful flower.

Six Glory of the Snow.

Two Star of Bethlehem.

Ten Beautiful Winter-blooming Oxalis, all different; and we will add to this collection

Two Calla Lilies, making - $3 /$ unequaled bargain.

MISS ELLA V. BAINES, THE WOMAN FLORIST, SPRINGGIELD, OHIO. 


\section{MY "SUPERIOR" COLLECTION OF SINGLE NAMED HYACINTHS.ว2}

PBICE, 10 cents esch; or the set of twelre for $\$ 1.00$. Any aix for 50 cents. Tw0 gets for $\$ 1.75$.

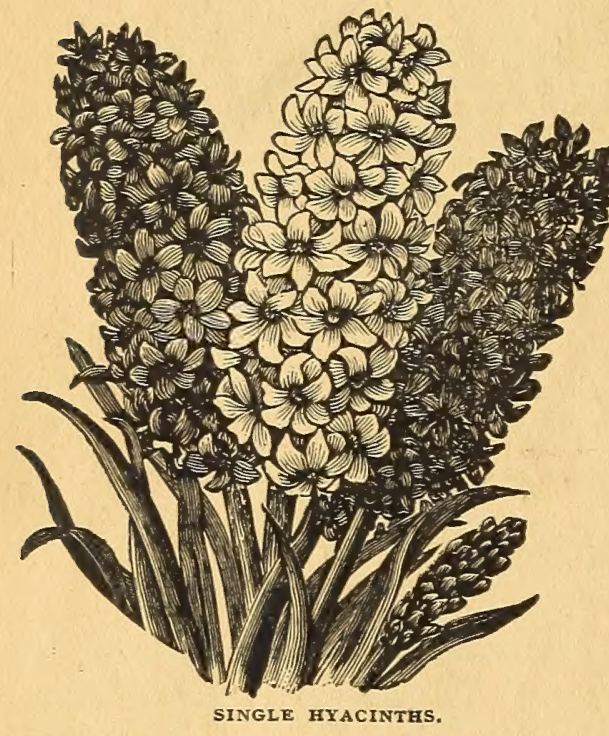

I wish I could persuade my friends to plant and cultivate more single Hyacinths. The spikes of bloom are larger, they are much more showy, and last as long as the Double varieties. This collection embraces all colors and shades, and the varieties are excellent. Try a collection.

Baron Von Thuyll.-Rich, deep blue; very large and free. Extra fine.

Grand Blanche Imperial. - This superb Hyacinth is certainly grand. Splendid, immense spike of large, pure ivory bells, waxy in appearance, vying with the snow in purity, while its fragrance is delicate, yet penetrating. Simply exquisite. The best of all.

General Gordon.-Richest deep golden-yellow, large spike. The very best in cultivation.

Grand Maitre-Deep porcelain blue; one of the grandest of all blue Hyacinths. Much prized in Holland,

Grandeur a Merville.-Finest cream white; very large bells and spike. Very desirable.

Lord Macaulay.- This is said by all who have seen it to be the best rich red Hyacinth yet offered. The florets are extra large, spike solid and compact, and the fragrance is exquisite. The color is a dazzling, sparkling red. Very bright. New.

La Grandesse. - This variety deserves the name of "The Grandness," having a grand spike of the purest white.

Queen of Hyacinths.-Deserves its name, being the very finest rich scarlet. Roi des Belges.-Rich, dark red. Extra fine and very early.

Sultan's Favorite.-Waxy-pink, striped bright red, A most handsome sort. Temple of Solomon.-Large, tall spike; large and very shapely, with very drooping bells. Flowers shell-pink inside and deep pink outside, touched with violet. A superb new sort.

Uncle Tom.-The very darkest, almost black. A beauty.

IN ORDERING, SAY "SUPERIOR" COLLECTION.

Get a friend or a neighbor to join you, and order two or more sets.

\section{"MONARCH" Set of Named Double Hyacinths}

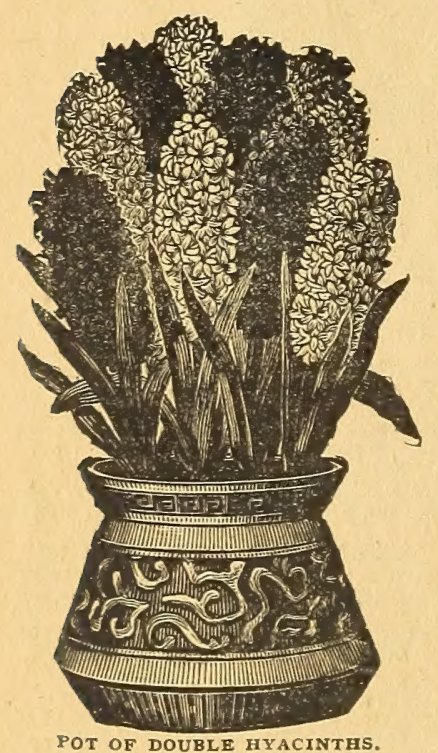

Charles Dickens.-One of the finest pinks. Extra large spikes. Grand Monarque de France.-A beautiful cream-white. A new shade in Hyacinths.

Gertrude.-Large, compact spike of beautifil bright red. An extra fine variety.

Jenny lind.-Very large spike of blush-white, with violet eye. Extra fine.

Ls Tour de Auvergne.-A beautiful, pure snow-white, with delicate rose tracings. Superb.

Lord Wellington.-Deep porcelain, with lilac stripe. The best of its color.

Monarch.-Bright crimson, with fine large spike. A most charm ing, rich colored, hardsome variety.

Plas Ultra.-Pure, waxy-white, very large bells. Extra fine for cutting, for which purpose it should be more extensively

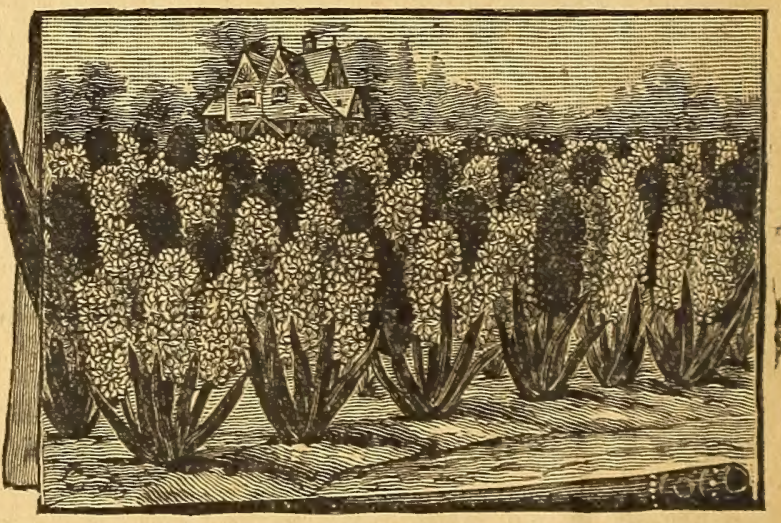

BED OF DOUBLE HYACINTHS. used. It is also very useful for outdoor because of its erect habit.

Princess Royal.-Deep scavlet; extra large, compact spike; very early. Is found in every collection for exhibition, which is a proof of its great value.

Pleneman.-The finest of all double light-blue Hyacinths, Has a large, compact spike of splendid lilac.

Rosea Maxima.-Fine pink, very compact spike. This variety has the lead of its color. It is very fine for forcing on account of its color and size of flower, and also very fine for outdoor, as it always stands erect.

Sans Souci.-One of the finest pink Hyacinths in cultivation. Has a large, compact spike and large bells. It always gives satisfaction, Those who know its value use it largely. 


\section{General Collection of Hyacinths.}

Send me $\$ 1.00$ and you can select twelve of these choice Hyacinths.

The cream of existing varieties, selected for my trade by the most reliable growers of Hollatid. Read the following list carefully. Price, 10 cents each; any six for 50 cents; any twe1ve for $\$ 1.00$.

Alba. Superbissima.-(Thebe.) Grand forcing, pure white variety. Alba. Superbissima.- Thebe.) Grand forcing, pure white variety. Anns Carolina.-Citron-yellow. One of the

Czar Peter. - The finest of all blue Hyacinths. Simply grand.

Cac de Malakofi.-Large spike of lovely orange shade.

Generai Pelissier.-Deep scarlet, early, good forcer. The richest red of all Hyacinths.

Gigantea.-The giant-flowered Hyacinth. Deep pink color,immense.

Grand Lilas.-Immense truss and bells, lovely porcelain-blue color. Much admired.

Grand Vedette.-A charming variety with large bells and spikes. Haydn.-A large spike of rich violet. The only variety of this Haydn.-A Extra fine.

Herman.-Orange-yellow color, flushed and tinted with crimson. Extra.

Heroine.-Pure yellow ground.

Ida.-Citron-yellow. The largest spike of all the yellows.

Johanna.-By many considered the best orange-colored Hyacinth.

The foregoing "General Collection" of twenty-six choice Hyacinths will be sent for a remittance

King of the Blues.-Dark blue, very large spike. The finest dark La fitronerre,-Citron-yellow. Very rich and very popular. La Peyrouse.-Light blue. Fine for beds and forcing. A very large, compact spike and large bells. A grand variety.
Madame Vanderhoop.-Pure white, with very large bells. Fine for cutting purposes. Extra.

Maria Catherina.-(Robert Steiger.) Extra light-red, fine, large spike and bells. Elegant.

Mina.-Pure snow-white. Very desirable. One of the best.

Moreno.-A lovely shade of deep rose.

Norma - This is one of the old standbys, and is a general favor Paixe, Lovely pink.

de la Europe.-Very finc. Snow-white, large spike and Queen of the Blues. - A lovely sky-blue. One of the very best

Regulus,-Light blue, with deep, dark blue stripes. Very fine,

William the First.-Dark blue spikes. Extra.
large spike.

of $\$ 2.00$. Try them. Every one a beauty.

\section{BED OF ONE HUNDRED OF THE VERY CHOICEST NAMED}
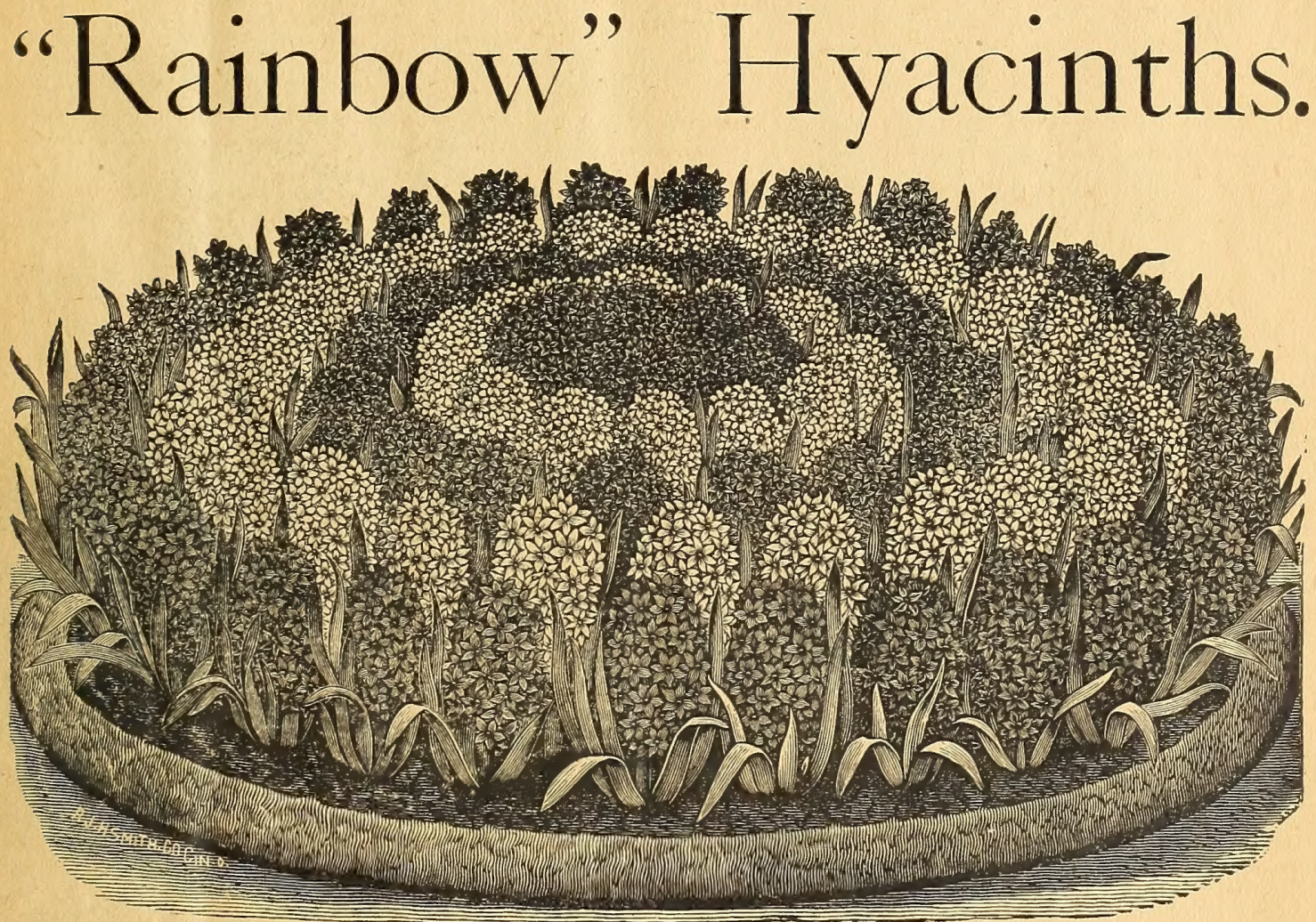

RAINBOW BED OF HYACINTHS.

This bed is fifteen feet in circumference, or five feet across. It is composed of five rows, requiring one hundred bulbs. This bed, when seen in flower, you will remember with pleasure as long as you live. Nothing can be more beautiful and fragrant. This bed is fifteen feet in circumference, or five feet across, requiring one hundred bulbs planted six inches apart-all for $\$ 6.00$. Or the bed can be reduced in size one half, when fifty bulbs will be required, costing \$3.00. In ordering, say "Rainbow Bed of Hyacinths." The varieties and colnese are as follows: Row 1, the center, twelve-LORD MACAULAY_dazzling scarlet. Row 2, fourteen-LA Sa'Candent -beautiful citron-yellow. Row 3, eighteen CZAR PETER-finest Porcelain-blue. Row 4, twegka, or seventy-Rive ESSE-the finest snow-white. Row 5, thirty-GIGANTEA-the best pink. cair these bulbs, to wake a 


\section{Mixed Hyacinths.}

T

HESE mixed Hyacinths are used almost exclusively for bedding out in the Fall on account of their cheapness. They are just as good colors and just as fragrant is in the cost of keeping the named sorts separate, both while planting and after they are dug. The exact shades cannot be given, but the general outline of colors are kept separate, so that in ordering you know what color you are bnying. Price, 5 cents each; or the entire twenty choice varieties for $\$ 1.00$.

Double Red; Double Rose; Double Pink; Donble Pare White; Double BInsh; Double Blne; Doable Light Blue, or Porcelain; Double Red, striped white: Single Rod; Single Rose: Single Light Blne: Single Pare White: Single Pink: Bingle Blue, or Porcelain; Single Red, striped white: Single Blush.

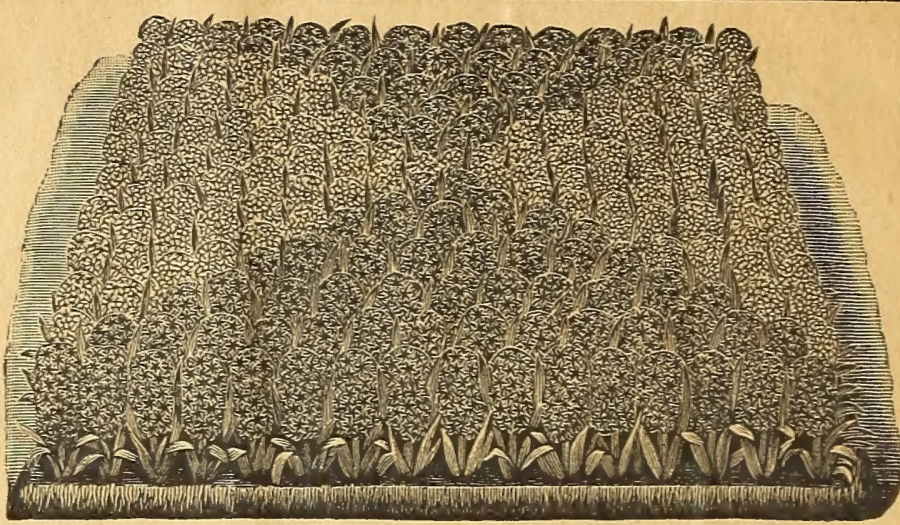

Remember, the above choice collection of sixteen Hyacinths for only $\$ 1.00$; any eight for 50 cents.

They are all different. In ordering, say "SIXTEEN ASSORTED HYACINTHS," or order the color you want at 7 cents each.

THESE ARE NOT SMALL, "TRASHY" BULBS, BUT IN EVERY WAY FIRST-CLASS.

\section{Roman Hyacinths.}

Seo front corer for illustration of Roman Hyacinths.

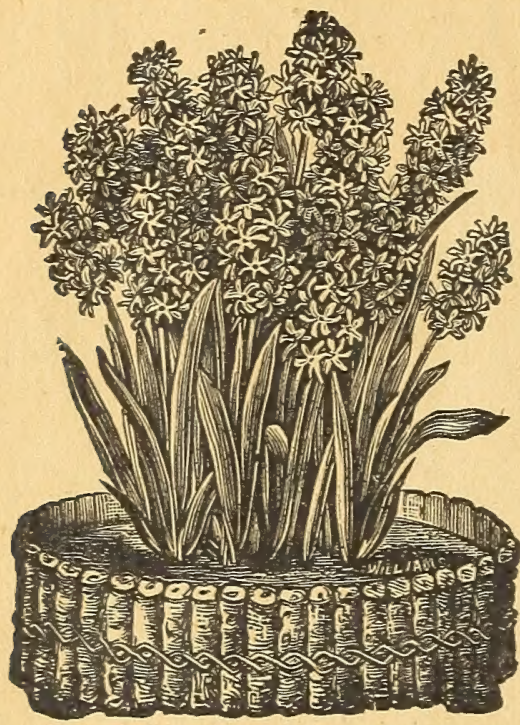

RUSTIC BOX OF ROMAN HYACINTHS.

The points of merit that commend this family of Hyacinths to me are many. First, they are early-can be brought into bloom for the holidays, a season when flowers are scarce. Second, they throw up several spikes of bloom to the bulb. Third, they are so easy of culture, once planted they take care of themselves, Tr a set. They can be potted at intervals of two or three week art and you can have flowers all through the Winter.

Bingle White.-Has elegant waxy-white bells of great beauty and fragrance. Price, large bulbs, 5 cents each; six for 25 cents; twelve for 50 cents.

8ingle Blue- - Lovely light blue, a fine contrast to the white variety. Price, 5 cents each; six for 25 cents; twelve for 50 cents.

Double Dark Pink.-A grand new sort, with enormous double, bright deep bells, in large spikes. Price, six cents each five for 25 cents; twelve for 50 cents.

Cansr Yellow.-New. Few novelties will come out this year which will in importance surpass this new yellow Roman Hyacinth. There is nothing to be said of it except it is like the common Roman white, except in color, which is a lovely of light yellow. Price, Io cents each; six for 50 cents. - QRR. - For only 25 cents I will setid oue

\section{Feathered Hyacinths}

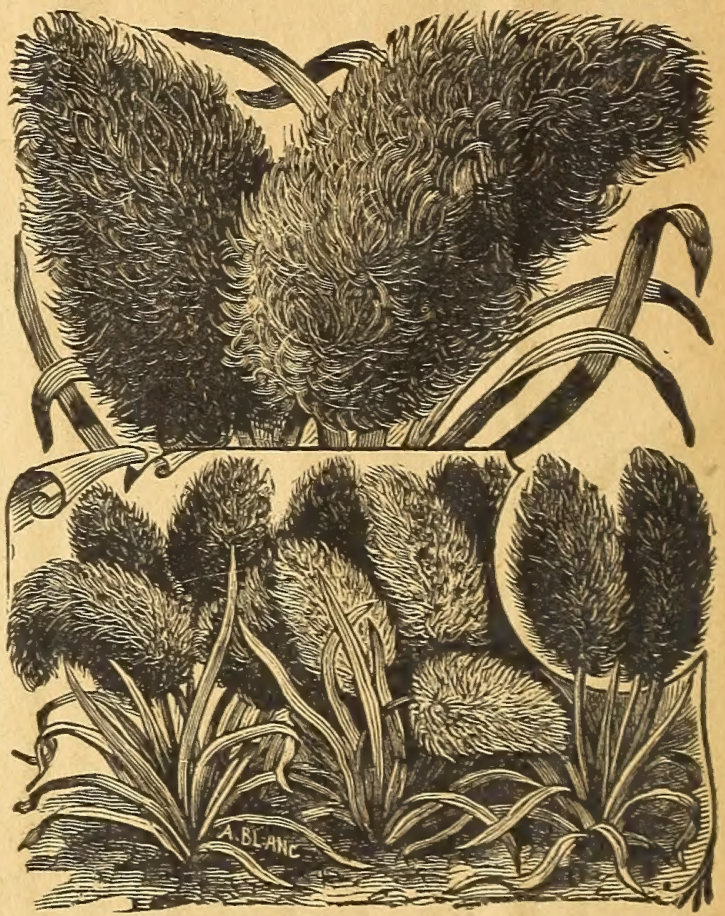

GROUP OF FEATHERED HYACINTHS.

A very pretty and curious species of Hyacinths, the flowers of which are a feathered plume, borne on the end of a large spike. It is perfectly hardy, and is particularly adapted for open ground culture and for indoor culture. Price, 5 cents eacb; six for 25 cents.

\section{SPARAXIS,}

From the Cape of Good Hope, producing filowers about the size and shape of those of the Crocus. The colors are of an in. finute variety. Pure white, yellow, orange, red, purple and violet are to be found, either separate or blended, in pleasing variation. Three or four bulbs may be put in a four-inch pot with good effect. They are charming. Try them. Price, 3 cents each; $3^{\circ}$ cents per dozen. 


\section{THE GRAPE HYACINTH.}

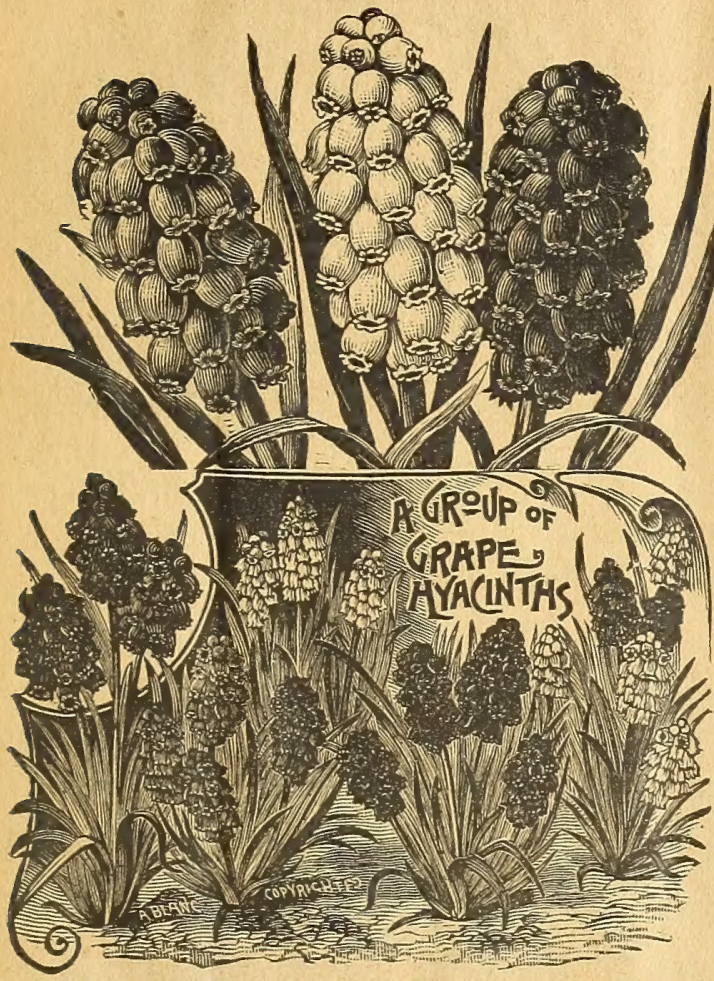

IMPROVED. This charming little rem should be found in every garden in abundance. It has been termed the "Blue Lily of the Valley" and when planted in a mass with that sweet flower it does resemble is to some extent, and forms a most fascinating combination. It grows about the same height and blooms about the same time each Spring. It increases rapidly and when once planted a mass of beautifai blossoms, which will increase each year, is insured for a lifetime. But for Winter blooming in pots it is of the greatest value. Plant five or six bulbsin a five-inch pot, and you will have as lovely a pot of bloom as you can imagine. Words fail to do it justice. Flower stems row a foot in height, bearing a dense spike of sky-blue bells tipped with white, and oh! so lovely. Please remember that mine is an improved strain of Grape Hyacinth, much superior to the old form.

Improved Blue.-Price, three for 5 cents; twelve for 15 cents.

Snow White.-New and scarce. Price, 2 cents each; six for 10

\section{Scilla Siberica, or Squill.}

\author{
(STAR HYACINTH.)
}

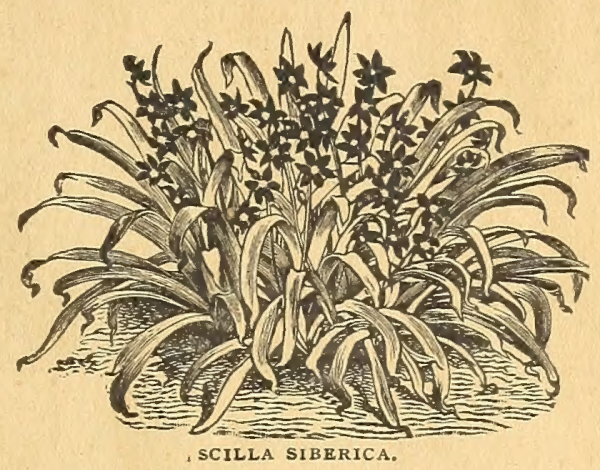

Scilla Siberica is one of the loveliest Spring flowers. It has a color almost as deep as the sky itself. Quite hardy, and flowers out of doors at the same time as the Snowdrop, in front of which it has a charming effect. Planted in pots and kept indoors it may be had in bloom as early as Christmas. Its magnificent bright blue color makes it suitable for any decorations whatever. Price, two for 5 cents; 25 cents per dozen.

SCILIA NUTANS. Belgian HJacinth. Habit like Hyacinth, a spike with bells suspended. The bells are half the size of Hyacinths. Colors very distinct and attractive. They bloom in May. The colors are blue, pink and white. Price, either of the three colors you may desire, two for 5 cents; 25 cents per dozen.

\section{ORNITHOGALUM ARABICUM.}

T INTRODUCE this as a new Winter-blooming buib of great 1 beauty and value. In magnificence there is nothing like it Hyacinth It is a native of Arabia. Bulb large and solid, closely resembling that of a Hyacinth, and requiring exactly the same culture. The leaves are long and narrow, flower spikes eighteen to twenty. four inches high, strong and graceful, bearing an immense cluster of large, pearly-white flowers, having a jet-black center. The individual flowers keep perfect many weeks before fading for more than a month this grand -spike of bloom is in full glory. Its durability is almost without an equal among flowers. Add to this its delicate, aromatic fragrance, and I have a Winter bloomer which all must admit stands without a rival Its culture is the easiest, as it will grow in any position in any window. A bulb can be planted in a four-inch pot, or several in a larger pot or box. Pot in September, October or November. They can even be kept and planted as late as February Ist. For open ground culture they do well if protected from treezing se20 cents.

\section{THE "STAR" BED OF TULIPS.}

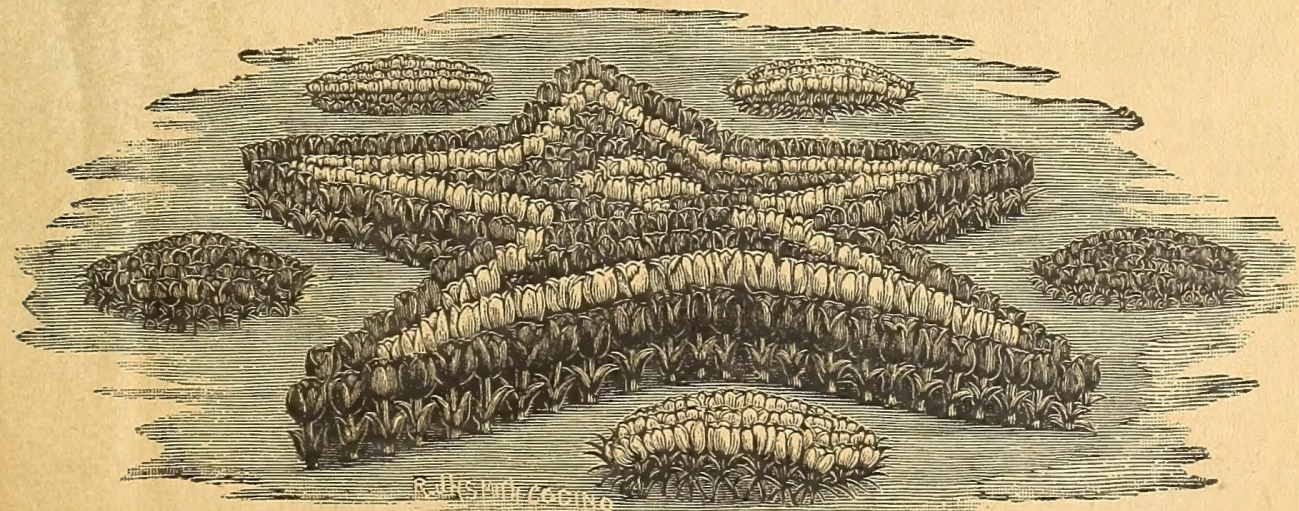

This beautiful bed is geven feet from point to point, and requires two hundred and fifty bulbs planted fone inches apart. Price, $\$ 4.50$, or for $\mathbf{a}$ bed half this size, one hundred and twenty-five bulibs, $\$ 2.25$. Section onte, center, ten Coutt of Leicester (yellow); section two fifty Rex Rubrorun'scarlet, section three, eighty La Canderir (white); section four, outside row, one hund red and teth M Cousine varierated red and yellow The of Tulips, as shown in small beds surrounding "Star" bed bulbs in all, for \$1.50; or the entire $10 t$ of $T * 1$ ips to make the above effect for $\$ 6.00$. Half these bulbs, to make display half this size, $\$ 3.00$. Try this design and be delighted. 


\section{Double Tulips}

H

A E massive flowers of brilliant and varied colors, shades and markings, and being double, the flowers last much longer in b oom than single varieties, and in conjunction the "time of the Tulips" is greatly prolonged. Double Tunction the "time of the Tulips" is greatly prolonged. De rarden, arour around the edge of shrubbery. They are robust growers and grown in pots for Winter-blooming, but must be forced much slower than Single Early Tulips by keeping them cooler.

Price, 3 cents each; or the Set of twenty-three different choice, distinct kinds of Double Barly Tulips for 60 cents. Those preceded with a star are the best va= rieties for forcing indoors.

Alba Maxima - Cream white. Very desira ble.

*Couronne d'Or. -The best golden - yellow. Resembles a Rose in shape. No flowe has a richer color.

Count of Leicester. Yellow, reddish Yellow, reddishder. Flowers at same time as La Candeur and Rex Rubrorum clear, bright red with white edge.

Gloria Solus.-Brownish-red, bordered with pure gold.

Helianthns.-Beautifully variegated red and

* Imperator Rabrorum.-A very fine bright scarlet. The finest of its color.

La Candeur. - Pure white. Fine bedder. This variety is bean tiful when is beautiful when planted among Rex Rubrorum, to form designs, inches apart. We sell an immense quantity of them, be ing very cheap. Price. $\$ 2.00$ per hundred.

Lo Blazon.-Fine, rosy

Le Biazon.-Fine, rosy-

Mink, very elegant.

rich violet, wh ite

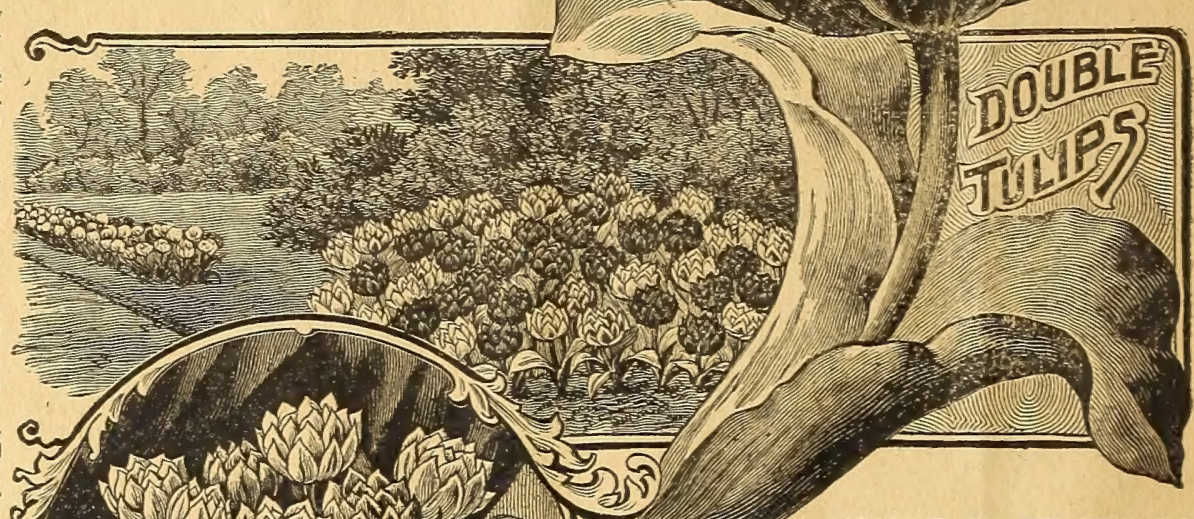

edged. This variety blooms at the same time as Rex Rubrorum and $L_{\mathrm{B}}$ Candeur, and makes an elegant border for these varieties.

* Murillo.-White, delicately flushed with pink, large flower. Fine for forcing or bedding

Purple Crown.-The only real dark red double Tulip. Very rich and effective.

Queen Victoria, -Rich wine color. Very distinct.

Kex Rubrorum.-Richest scarlet. Beautiful when planted among La Candeur to form designs of any description, as they grow of equal height and bloom at the same time. A rich effect is produced by planting Rex Rubrorum in center of bed then surround this with $\mathrm{c}$ ( Candeur, cester. They all bloom at one time. Price, $\$ 200$ per hundred.

* Rosina.-A beautiful, rich, clear pink. Fine forcer.

Rose Blanche.-Pure white. Splendid bedder.

Bubra Maxima.-Dark velvety-scarlet, immense, large flower * Salvator Bosea.-Deep dark pink Fine forcer.

Titian.-Brown, splashed with golden yellow,

Tournesoll.-Elegantly variegated red and yellow.

* Tournesoll, Yellow.-A deep, bright golden-yellow, Extra.

Turban.-Deep violet, very dark and distinct.

Velvet Gem.-A rich velvety-rrimson. Fine.

\section{DARWIN TULIP,-(Late Flowering.)}

A new family of Tulips. Grows three feet high, bearing immense large flowers, three to four inches in diameter. The most unique and richest colored of all the Tulip family. The colors run from flesh-pink, through scarlet, to the deepest violet. No white or yellow flowers among the Darwins. Very late flowerIng. Price, 5 cents each; six for 25 cents.

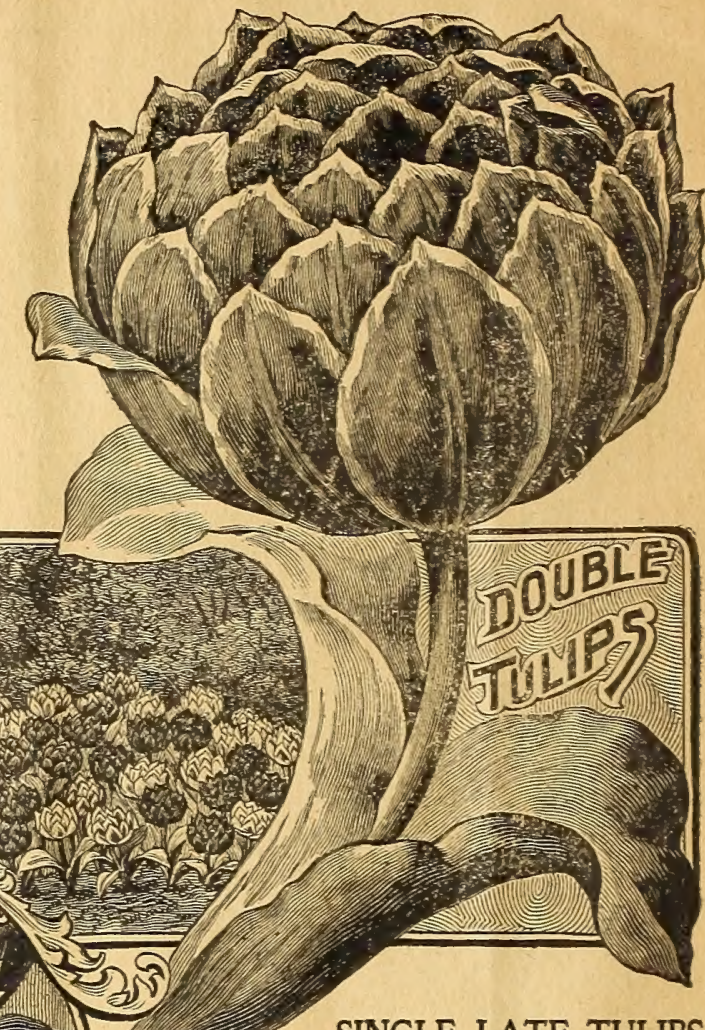

SINGLE LATE TULIPS.

(CALLED BYBLOOMS

White grounds, variegated with various colors. Fifty finest sorts, mixed. Price, 3 cents each; twelve for 30 cents.

\section{SINGLE LATE TULIPS.}

(CALLED BIZARRES.)

Yellow grounds, variegated with various colors Fifty finest sorts, mixed. Price, 3 cents each; twelve for 30 cents.

SPECIAL OFFER.-For only 50 cents we will send twelve bulbs each of Byblooms and Bizarres.

\section{LATE FLOWERING DOUBLE TULIPS,}

\section{NAMED VARIETIES,}

Price, 3 cents each ; or the Set of five for 12 cents. Blue Flag.-Richest sky-blue. The only Tulip of this color. Mariage de Ma Fille.-White, with cherry-crimson, feathered. Extra fine.

Overwinnasr.-Blue and white-feathered. Extra.

Pronygold.-A rich scarlet, feathered yellow.

Yellow Rose. - Splendid golden-yellow, very large flower. The best of the yellow Trulips. Extra. Price, $\$ 2.00$ per hundred.

\section{LATE FLOWERING SINGLE TULIPS. \\ NAMED VARIETIES}

These late Tulips flower long after the other varieties of Tulips are gone. They have beautiful flowers and are valuable for ? succession.

Price, 4 cents each : 40 cents per dozeu.

Bouton d'0r.-Pure yellow; the deepest yellow Tulip in existence.

Golden Crown.-Yellow, bordered with bright red.

Gesnerisns.-Beautiful scarlet; very large flower. Tall grower. Sulphur Crown.-(Maiden Blush.) White, with pink borders. Very beautiful. 
Miss Ella V. Baines, The Woman Florist, Springfield, Ohio.
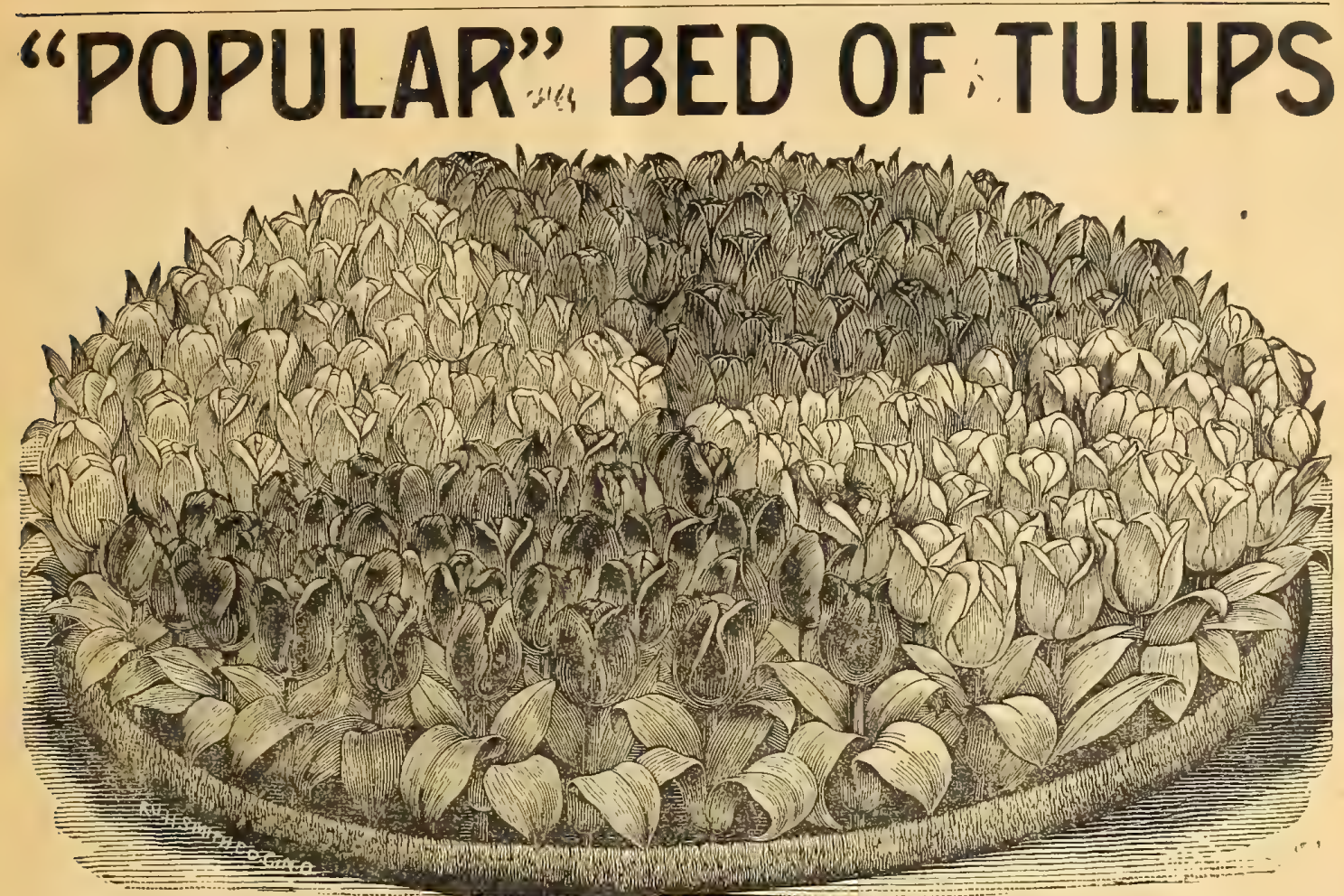

"POPULAR" Bed of Rex Rubrorum (bright scarlet) and La Candeur (pure white) Double Tulips. It is five feet across, or fifteen feet in circurference, and requires two hundred bulbs planted four inches apart. Price, for this bed, one hundred bulbs of each kind, $\$ 3.50$; or a bed half this size, fifty bulbs of each color, $\$ 1.75$. Don't fail to try a bed of these, and see how pretty they are.

\section{EARLY SINGLE-FLOWERING TULIPS.}

(NAMED.)

7. ULIPS are such universal favorites that it is scarcely necessary to expatiate upon their merits here. Their ease of culture, combined popular bulbs grown for Spring bedding, and for Winter-flowering in the greenhouse and window gardens they are incomparable. The Tulip is extremely hardy and of easy culture, flowering as freely in the shade as in the sunshine, and producing as fine flowers in a confined town garden as in a more favored place. Double and Single Tulips, when associated together and planted in front of shrubs, maintain a longer display than if either are separately planted. In gardens where the flower beds must be kept gay from the earliest day of Spring, plant between the lines of Tulips, Scilla Siberica, Chionodoxa Lucilliz, Snowdrops or Crocus, and as these flower first they can be removed or cut down when the Tulip is coming into bloom. The Single Tulip has a greater variety of rich, delicate and attractive colors than any other section of Spring flowering bulbs. Those only who have massed the different varieties, planting the bulbs four inches apart, can form an idea of their beauty and their great diversity in shade and color, and the grand effect they produce grouped in flower beds or borders. The Single Tulip is extensively grown for indoor decoration, three or five bulbs in a pot.

Artus.-Bright scarlet, splendid bedder. Flowers with La Reine

*Belle Alliance.-(Waterloo.) A clear scarlet. Flowers at same time of L'Immaculee aad Chrysalora.

Chrysalora.-Golden-yellow. Extra fine. It is the best single yellow Tulip for out-doors.

Cottage Ilaid.-(La Precieuse.) Snow-white, bordered with pink. The prettiest of all Tulips.

* Coleur de Cardinal.-Brightest red, outside of petals shaded Crimgonze.

Crimson King,-(Roi Cramoisi.) Good crimson bedder.

Coleur Poncean.-Wine color, center of each petal flamed white,

Duchess de Parma -Orange-yellow, tinted brown, very large.

Eleonora.-Richest royal violet. Extra fine.

Golden Eagle.-Fine golden-yellow, good bedder.

Jacht Van Botterdam. - Ground color white, flamed with violet. Joost Van Vondel.-Giant flower. Brilliant red, reverse of petals

* Kelserskroon.-Red, with broad yellow edge. Fine for pots. The largest of all Tulips.

Lac Van Rhijn.-Violet color, with broad white edge.

La Raine. - The Queen.) White, delicately shaded pink.

Leonard de Vinci_-Oránge. Very attractive color.

Price, 3 cents each; the set of thirty-fout distinct varieties of early Single. Tulips for 90 cents. The varicties preceded with a star are the best for forcing indoors.

L'Immacnleo-(Snowball) Snow.white, Extra large flower. * goud bedder. by Christmas.

Mr. Stanley.-Rosy-purple. Very attractive.

Princess Marianne.-White, slightly shaced pink. Very fine.

Prince of Austria.-Orange, shaded scarlet. Very large and

*Prosperine.-Magenta-red, very large. Forces by Christrmas. Rachel Ruisch. - White, with pink edges.

Roch ine

k

* Rose luisante - The best deep pink for forcing.

Standard Royal. - White base, veined scarlet, beautiful variega Stand

Thomas Moore. Buff-orange. Very showy. Vander Neer. - The finest of all violet-colore

Verboom -

Vermilion Brilliant - The best scarlet forcer, large flowe

* Thite Hawk.-Pure snow-white, splendid forcer, large flower.

Wonterman-Dark royal purple or blue.

Wapen Van Leiden -White. Ench petal has a violet top. 


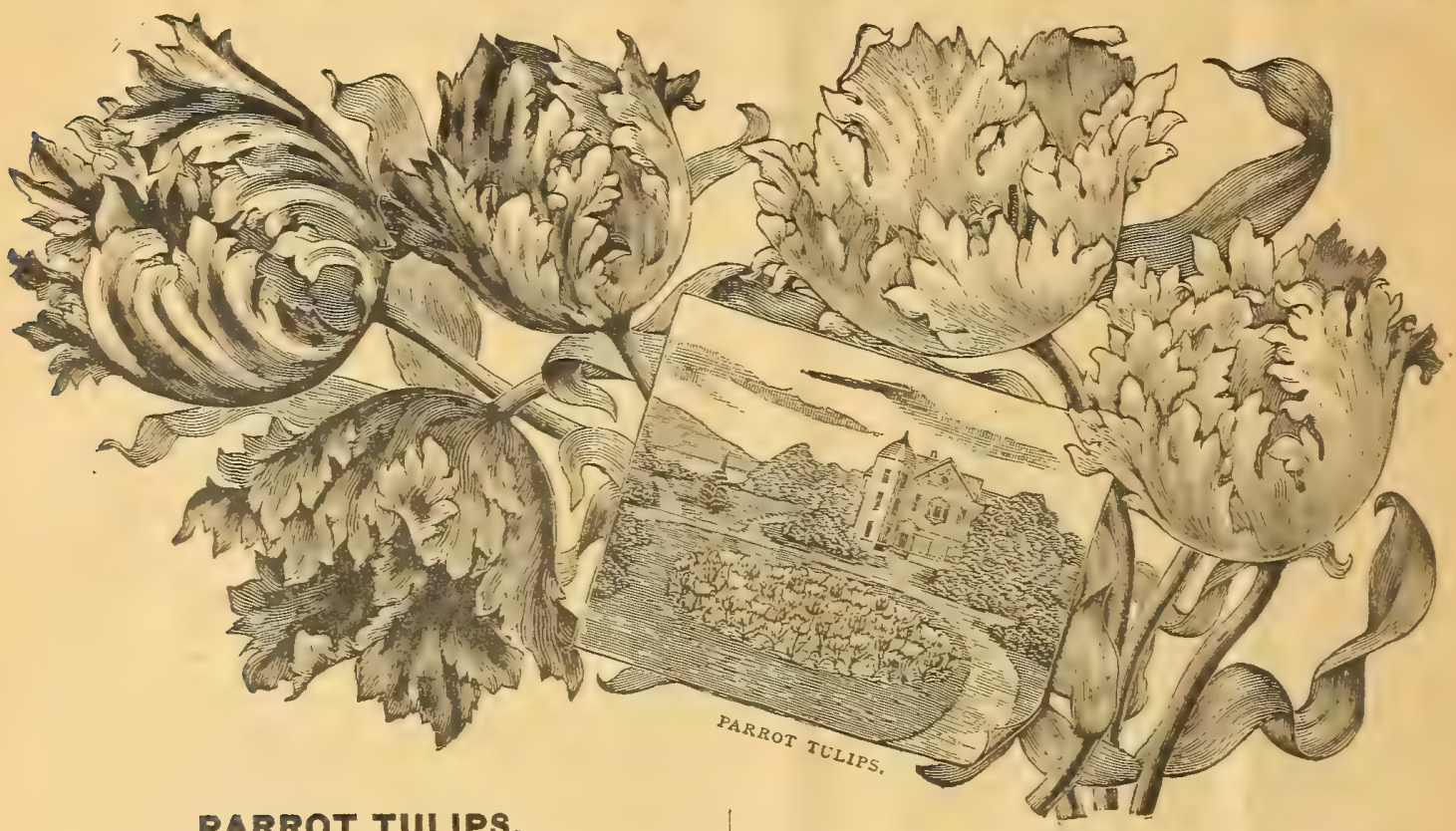

PARROT TULIPS.

The most beautiful and interesting class of Tulips, which should be in every garden. The flowers are very large and perfect in color is the most striking combination of crimson andrgoldenyellow, streaked and edged with green, resembling the plumage
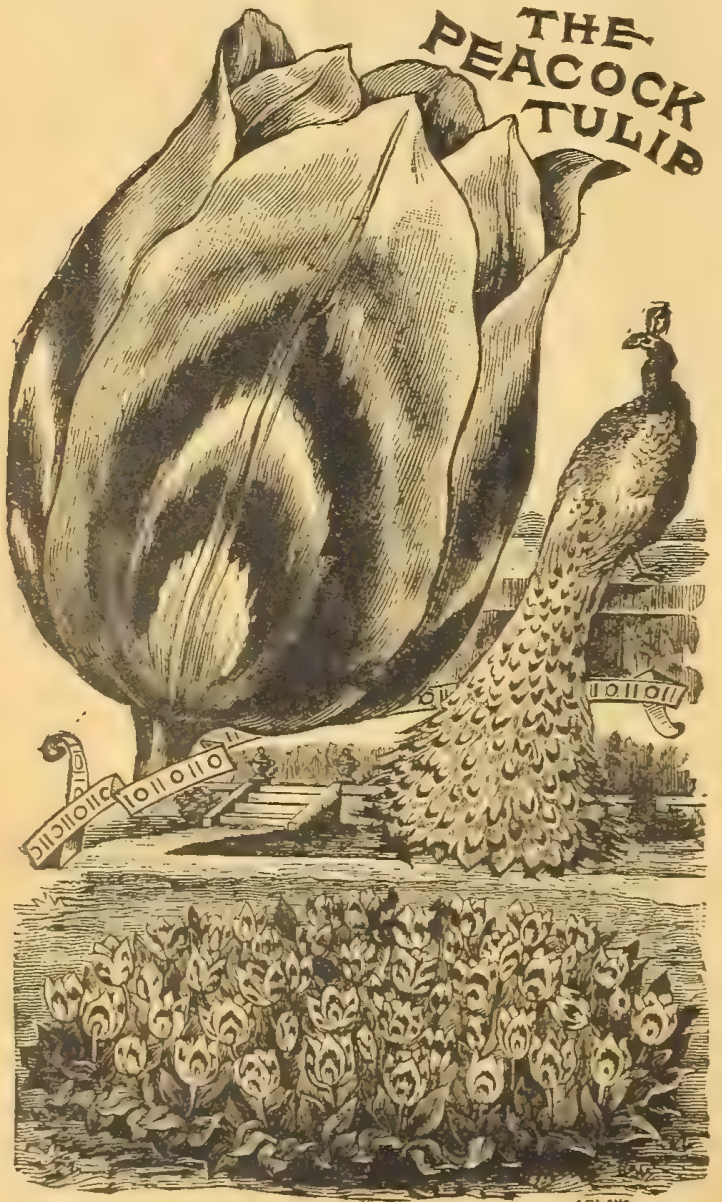

of a parrot, whence these Tulips derive their iname. A bed of these makes a gorgeous display, paying a hundred fold for any
trouble that may be bestowed upon them.

Price, 4 cents each: 35 cents per dozen.

Admiral of Constantinople.-Red, streaked with orange.

Coleur Cafo. - A dark brown color. Very desirable.

Glorio8a.-Yellow, striped with red.

Perfecta.-Yellow ground, shaded and spotted and scarlet feath. ered.

Harkgraf. - Yellow and orange.

Lutea Major.-Bright yellow.

Fine Mixed Parrots, - All colors,

\section{DUC VAN THOL TULIPS.}

They are the earliest to bloom of all the Tulips, and are greatly prized for pot culture during Wirter. In the garden they bloom with the Crocus, and are welcome heralders of Spring. Do not omit this charming class.

Price, 3 cents each; the set of eight for 20 cents.

Yellow, - Clear and brilliant.

Bose.-Beautiful delicate pink.

Scarlet.-Dazzling scarlet

Gold Striped.-Scarlet, striped gold

White, - Very fine.

Crim80n.-Beautiful crimson.

Violet. -The earliest of all.

Red and Yellow, - The earliest of all bulbs to flower; long before hecus.

BOTANICAL TULIPS. (Late Flowering.) Ocalus Solis.-(Pcacock Tulip.) Bright scarlet, with darker markings that resemble the peacock's feather. Very beautiful, Price, 5 cents each; 50 cents per dozen.

Silvestres - (Florentina Odorata) Yellow flowers, with delicious fragrance. This variety is the only Tulip that has fragrance. Price, 4 cents each; 40 cents per dozen.

Greigii-, inside of petals; bronzy-yellow outside; foliage black spotted. This variety and the Darwin Tulip are the handsomest of all Tulips. Order a Greigii Tulip and see what a beautiful flower they are. They cost us three times what other Tulips cost. Price, ro cents each.

\section{MIXED TULIPS.}

I have a large stock of unnamed Tulips for bedding, which I price so low as to make a Jarge mass of these showy flowers priter of trifing expense. They are excellent bulbs, and will bear handsome blooms. Double and single collections are kept separate. Several hundred bulbs at the quotations below involve less expense than is required to secure a few Summer bedding plants, and in the matter of display they are fully as valuable during their season as an equal number of ondinary blooming plants.

Superfine Mixture Single Tulips. - In fifty choicest kinds, splendid flowers. Price, 25 cents per dosen; \$2.00 per hundred.

Superfine Hixture Double Tulips. - In ffty choicest kinds, splendid flowers. Price, 25 cents per dozen; $\$ 2.00$ per hundred.

Superfine Mixture of Parrot Tulips-Price, 35 cents per dozen; 
Miss Ella V. Baines, The Woman Florist, Springfield, Ohio.

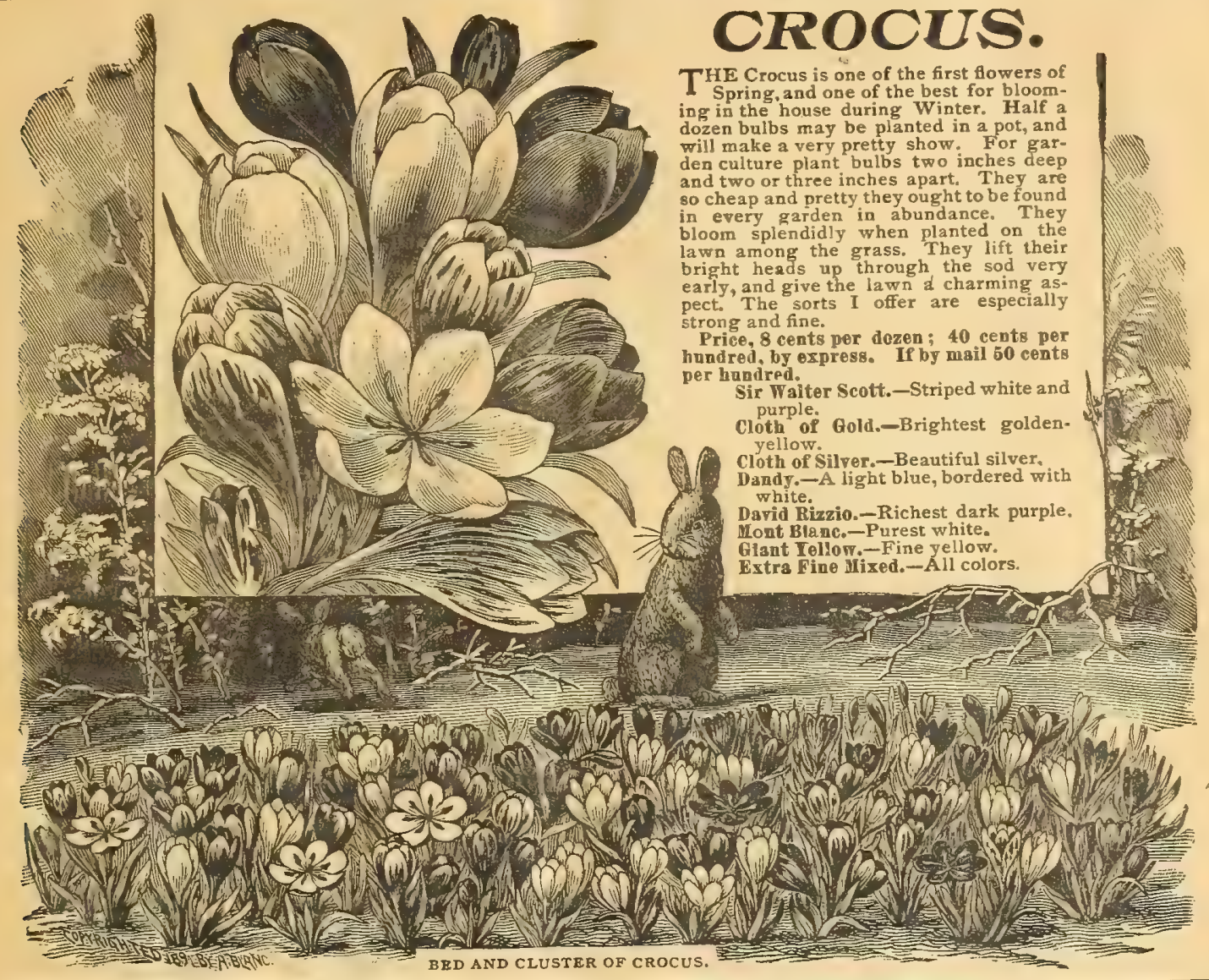

\section{Narcissus and Daffodils.}

WEET harbingers of Spring, that jump from old Winter's lap, with cheeks of gold and silver, and bedeck the earth with beauty, filling the air with delicious perfume. The wonderful creations in the way of new varieties have awakened an interest and enthusiasm among the lovers of flowers that has placed this, "The Flower of the Poets," in the front rank of popularity, and they merit all the praise that can be bestowed upon them. Appearing, as they do,just after bleak Winter, they turn our gar.
dens, lawns and woodlawn walks into gorgeous masses of gold and silver, with a fragrance that is enchanting. They are equally valuable for growing in pots for Winter flowering, and some of the varieties are forced in immense quantities by florists for equally valuable for growing in pots for Winter fowering, and some of the varieties are forced in immense quantities by florists for has been much enriched, and embraces in addition to the old favorites many new varieties, including the magnificent new hybrids,

Note. - I wish to say to my friends that the different varieties of Narcissus force into bloom In the house during Winter as readily as the Hyacinth. There is nothing finer in the flower line for this purpose. Indeed, they are my choice of all Winter. readily as the Hyacinth. There is nothing iner in the flower line for this purpose. Indeed, they are my choice of all Wintera varleties: GOLDEN SPUR, POETICUS ORNATUS, ORANGE PHOENIX, SULPHUR PHOENIX, VON SION, HORSFIELDII, GIANT PRINCEB8, Varleties: GOLDEN SPUR, POETICUS ORNATUS, ORANGE PHOENIX, SULPHUR PHOENIX, VON SION, HORSFIELDII, GIANT PRINCEBE,
PAPER WHITE, CHINESE SACRED LILY and GOLDEN SACRED LILY. Try these varieties. They will not disappoint you. Nothing is prettier.

\section{LARGE TRUMPET NARCISSUS.}

Two Colored Varieties-White and Yellow.

Dean Ferbert.-A beautiful new variety, with very large, wide bright yellow trumpet and creamy-white perianth, very dis tinct. Price, so cents each; $\$ 1.00$ per dozen.

Bmpress.-A magnificent, large variety, bold and erect. A rare beauty. Some give this the palm of being the best of the two colored trumpets. Perianth white and of great substance; trumpet rich yellow. Price, 15 cents each; four for 50 cents.

Grandee,-Flowers of the largest size, with broad, snow-white petals and a magnificent yellow tube, Verybeautiful. A flower of great substance, and grand for cutting. Price, 15 cents each; six for 75 cents.

Horsfleldii. - The "Queen of the Daffodils." This variety is considered the best of all Narcissus. Try it. Very large, flowers pure white, with rich yellow trumpet. Very stately and beautiful, and one of the most elegant for ladies' corsage wear. This magnificent flower was raised by a Lancashire weaver-John Horsfield-and it has made him famous. Price, weaver-John Horsfield-and
Scoticus. - The "Scotch Garland Flower," or "Large Flowering Lent Lily." Large flowers of creamy -white, bright yellow trumpet, elegantly flanged and serrated. Price, 6 cents each; 50 cents per dozen.

Giant Princess.-(Ajax Princeps.) A magnificent flower. One of the finest specimens of the Trumpet type. Cream perianth. with golden-yellow trumpet. Price, 8 cents each; 75 cents per dozen.

Moschates.-White perianth. Trumpet opens creamy white and turns to pure wite. It is very large and showy, and it never fails to please everybody. Price, 15 cents each; four for 50 cents.

\section{A11 White Trumpet Narcissus.}

Pallidus Pracox.-The "White Pyrenees Daffodils." One of the earliest and most beautiful varieties. Both trumpet and perianth are clear sulphur-white. Was awarded a first-class certificate by the London Royal Horticultural Society. One of the best for forcing. Price, 6 cents each; 60 cents per dozeri.

Albicans.-The "White Spanish Daffodils." Creamy-white, with a silvery-white trumpet, slightly flushed with primrose and ele. gantly recurved at the brim. Price, to cents each; six for 50 cents. 


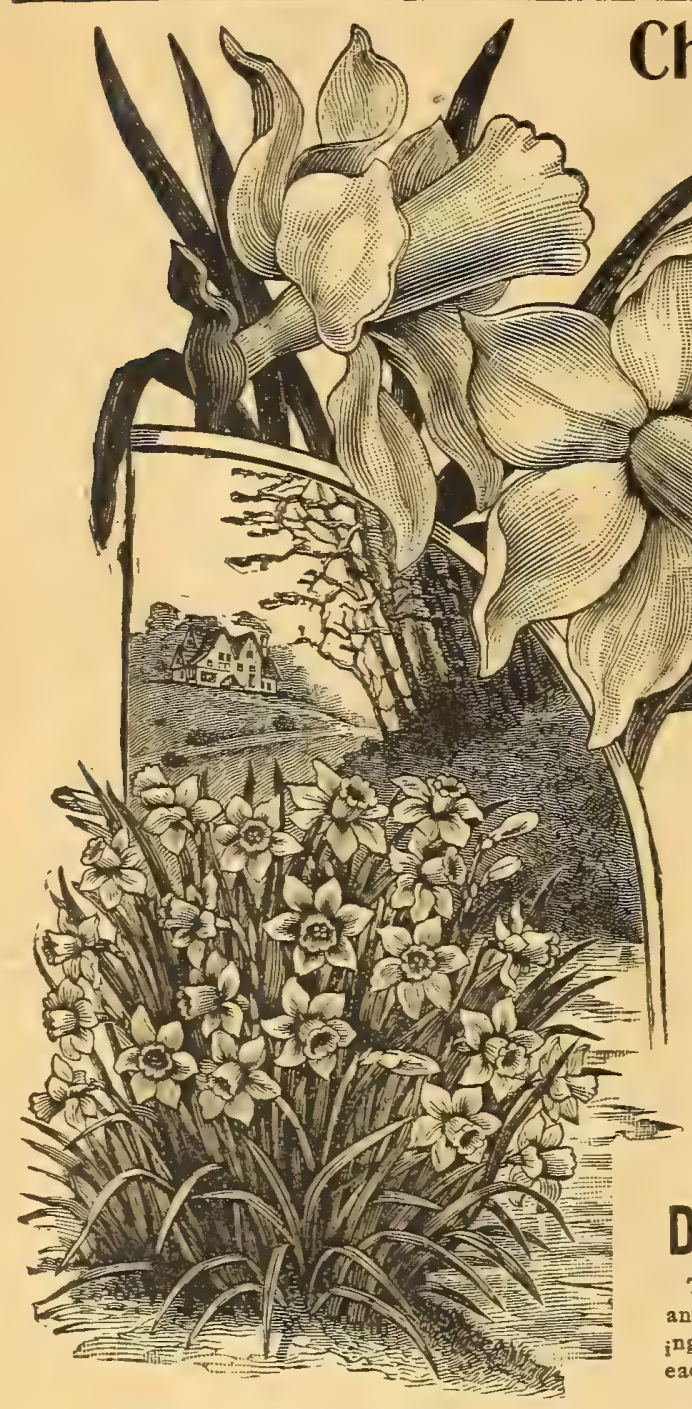

\section{Chalice Flower Narcissus}

TEACUP-SHAPED DAFFODILS.

A very pretty type that has always been held in high favor, as they are very beautiful.

Barri Conspicus.-Cup elegantly margined orange, perianth white. A charming flower for ladies? wear. It is one of the best for cutting, forces readily and holds the bloom well. The bulbs are small. Price, to cents each; three for 25 cents

Incomparabilis, Simplex.-(Great Nonesuch Daffodils.) Lovely in color and form. Sulphur.yellow petals, deep yellow cup. Without exception very desirable and fragrant. Price, 5 cents each; $5^{\circ}$ cents per dozen.

Incomparabilis, Albus Stella.-Perianth is large and pure white; cup or chalice bright yellow. Excellent. Price, 5 cents each; 50 cents per dozen.

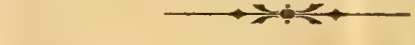

DOUBLE (Camellia-Flowered) MARCISSUS YELLOW VARIETY.

Incomparable, fl. pl.-"Butter and Eggs," Full double flowers of rich yellow, with orange nectary. Splendid forcing variety. Price, 4 cents each; 40 cents per dozen.

"Gardenia Flowered" WHITE VARIETY.

Alba Plena Odorsta, - "The Double White Poet's Narcissus," Snowwhite Gardenia-like flowers, exquisitely scented. Price, 4 cents each; 35 cents per dozen.

TWO COLORED VARIETIE8-WHITE AND YELLOW.

There are no finer Narcissus than the Orange and Sulphur Phønis. Especially is the Sulphur Phenix extra fine, The flower is as large almost as a Prony. Be sure and try them.

0range Phonix.-"Eggs and Bacon." This beautiful variety has double white flowers, with orange nectary, and is splendid for pot culture and cutting. Price, 6 cents each; 65 cents per dozen Solphur (or Silver) Phonix. - "Codlins and Cream." Large, creamywhite flowers, with sulphur nectary. Exquisite corsage flower, and fine for growing in pots. Price, 15 cents each; four for 50 cents.

\section{Double Trumpet Daffodil, VON SION,}

The famous "Old Double Yellow Daffodil." Rich golden-yellow perianth and trumpet, one of the best forcing sorts, immense quantities being grown for this purpose both in Europe and America. Price, 4 cents each; three for ro cents; 30 cents per dozen.
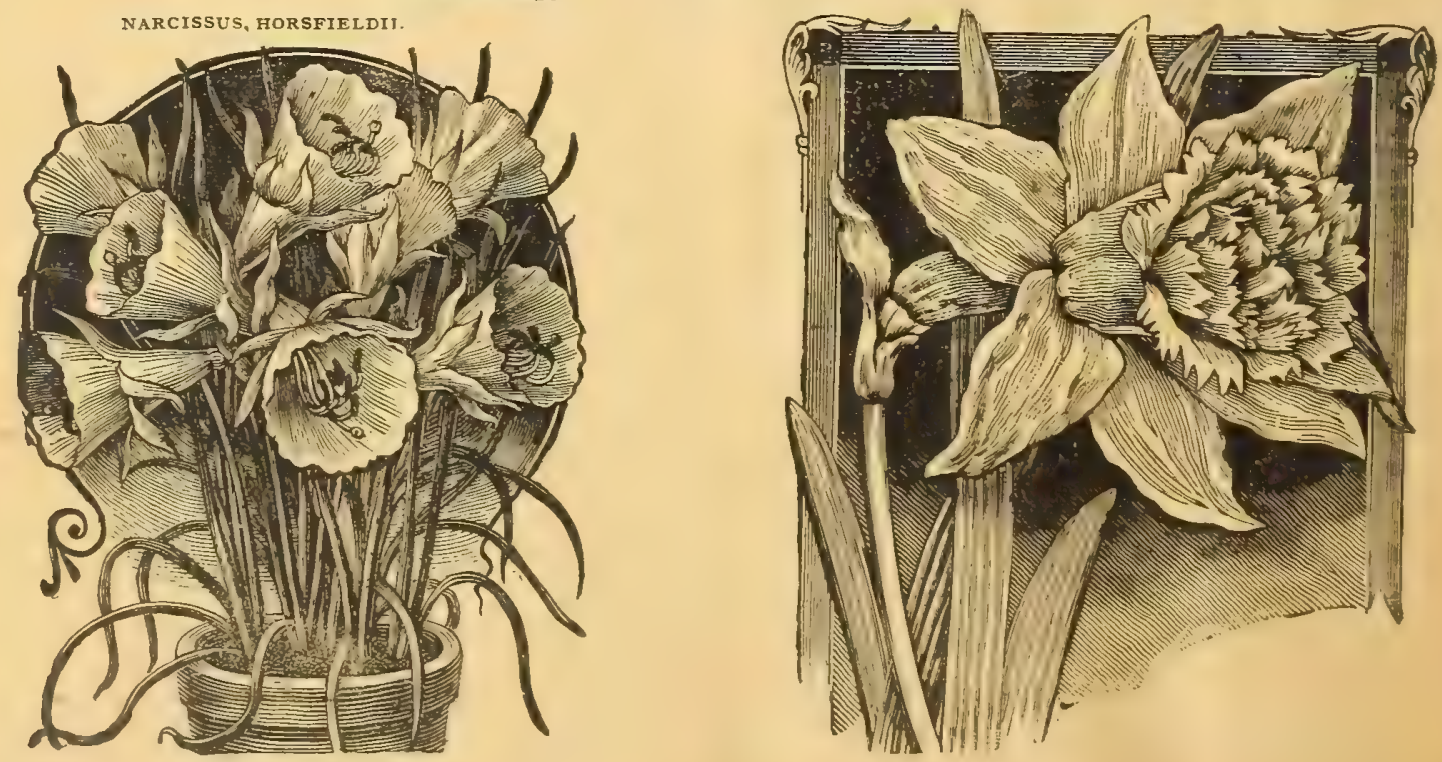
Large Trumpet Narcissus Yellow.

ARD-RIGH, or IRISH KING.

(Trumpet Major.) Earliest and most vigorous "Giant Trumpet Daffodil" in cultivation. Fine, bold flowers of immense size. Perianth and trumpet full, rich yellow. Extra fine sort for pot culture and forcing. Price, 6 cents each; six for 30 cents.

\section{EMPEROR.}

The Giant Narcissus, Largest of all. The flowers are of the richest yellow, trumpet immense, petals of perianth so large they overlap, and measure three and a half inches across. Petals a shade lighter than the trumpet. Price, 15 cents each; four for 50 cents.

\section{GOLDEN SPUR.}

Extra large, bold, rich, yellow flowers. Foliage very broad and striking, unusually robust habit. Unsurpassed for gardens, pots or forcing. Price, 10 cents each; \$I.00 per dozen.

\section{HENRY IRVING.}

Long, beautifully frilled trumpet nearly two inch. es wide at the mouth, of rich, golden-yellow color. Petals of perianth very wide, overlapping, bright yellow. Received first-class certificate. Price, to cents each; \$1.00 per dozen.

\section{HALE'S BEATEN GOLD, or MAXIMUS.}

Large flower, rich yellow, elegantly twisted periantb, trumpet deep golden, large, well flanged. Price, so cents each; \$1.00 per dozen.

\section{OBVALLARIUS.}

"Tenby Daffodil," Elegantly formed, mediumsized flower of rich yellow. Splendid for forcing. Price, 8 cents each; 85 cents per dozen.

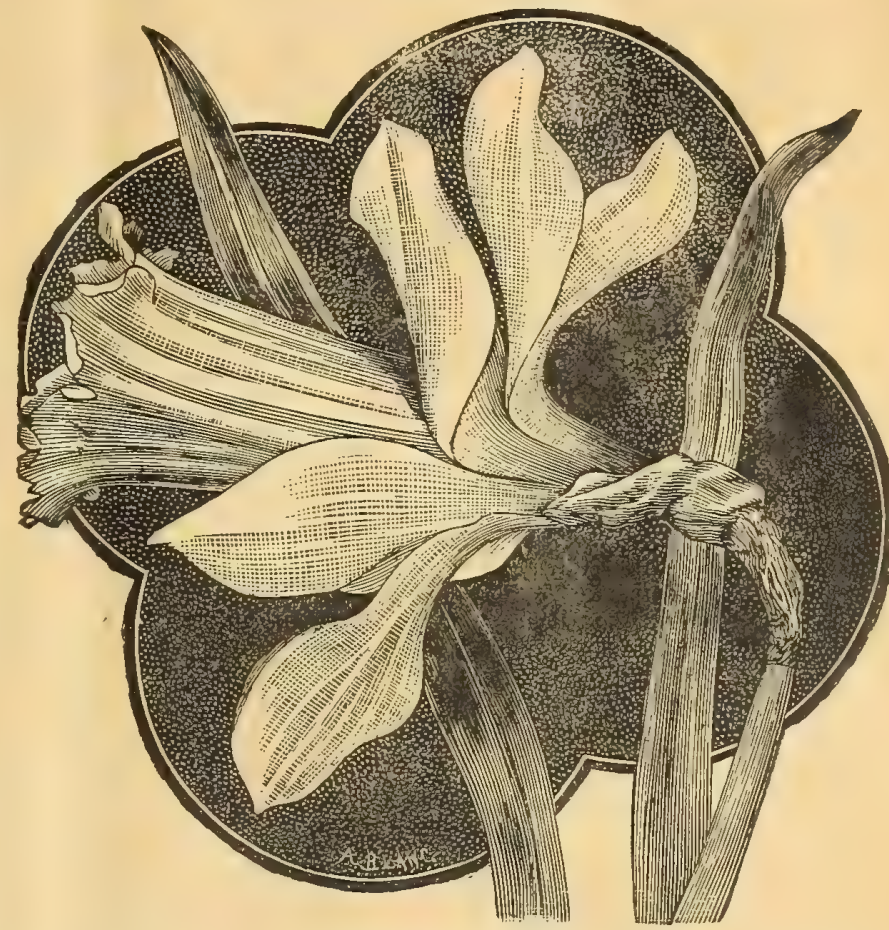

NARCISSUS, GOLDEN SPUR.

\section{The True Poet's Dafiodils.}

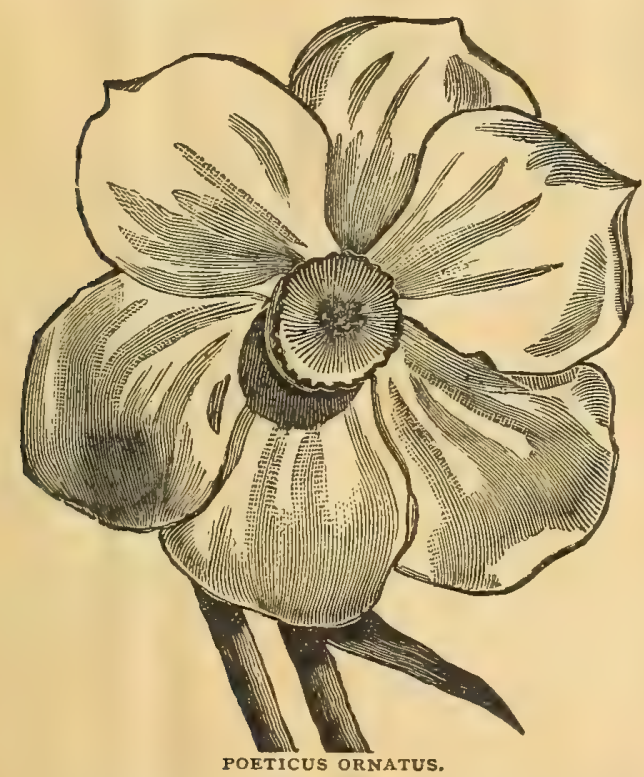

Hoop Petticoat, or Medusa's Trumpet Narcissus.

Bold and shapely flower. They are gems for pot culture, and bear from six to twelve flowers to each bulb. For planting in groups around the edges of lawns, and especially for edgings for beds, this class is superbly adapted. The bulbs of the Hoop Petticoat varieties are all small, but produce handsome flowers.

See illustration, page 12 .
Bulbocodium.-The " large Yellow Hoop Petticoat," rich goldenyellow. Price, 8 cents each; 85 cents per dozen.

Citrinam.-The "large Sulphur Hoop Petticoat," large sulphu flowers, unique and beautiful. Price, 5 cents each; 50 cents per dozen.

"Algerian White Hoop Petticoat."-(Monophyllus, or Clusiz.) Pure snow-white, very early, will bloom at Christmas if potted in September. Price, 8 cents each; 85 cents per dozen.
NARCISSUS, WITH MINIATURE SAUCERSHAPED CUPS.

Biflorns - (Two-flowered Poeticus.) Twin flowers borne on one stalk. The color is pure white, with yellow cup. Price, fou for Io cents: 25 cents per dozen.

Poeticus Ornatns-Large, beautifully formed, pure white flow ers, with saffron cup, tinged with rosy-scarlet. A magnificent cut flower. Very early. This is our special favorite of all Narcissus. Try it. Price, 5 cents each; 50 cents per dozen

Poeticus.-The "Pheasant's Eye," or "Poet's Narcissus." Pure white flowers, with orange cup, edged with crimson. Splen did cut flower. Price, four for 10 cents; 25 cents per dozen.

Poeticus Poetarum.-New. The flowers of this new variety are much larger and the orange rim more distinct in the cup. This beautiful variety provement over the old Poeticus. Price, 5 cents each; 50 provement over

\section{POIYANTHUS NARCISSUS, or BUNCE- FLOWERED DAFFODILS.}

The Polyanthus varieties of Narcissus are not only beautiful but deliciously sweet-scented and of the easiest culture. Very free flowering, and suitable for window garden, conservatory of garden, continuing long in bloom, They bear tall spikes of bloom, bearing from six to twenty-four flowers each. The pure white petals and gold cup of some varieties, the yellow, with the orange cup of others, and the self-whites and yellows, render them great favorites.

NOTE - Polyanthus Narcissus, although not considered hardy, have lived out for two Winters in the vicinity of Boston with a slight covering of straw and leaves, and produced much larger fiowers, and more of them, than when grown in the house in pots.

\section{WHITE VARIETY.}

Paper White.-(Totus Albus.) Pare snow-white flowers in clus ters. This variety is perhaps more largely forced for cutflowers than any other, millions of them being used for the large flower markets of the world. Price, 5 cents each; 40 cents per dozen.

YELLOW VARIETIES.

Grand Soliel d'0r.-Rich yellow, with reddish orange cup. A favorite bedding and cutting variety. Price, 8 cents each; 75 cents per dozen.

Gloriosus.-Immense trusses of pure white, with primros:-col ored cups. Very early. Splendid to force. Price, 8 cents each; 75 cents per dozen.

Double lioman.-Clusters of white flowers, with double citron colored cups, It is very early, and grown principally and largely for forcing. Price, 5 cents each; 40 cents per dozen.

Chinese Sacred Lily.-See description and illustration on page 14 Price, 15 cents each; four for 50 cents. 


\section{THE CHINESE SACRED}

\section{Oriental Narcissus}

\section{A Variety of Polyanthus Narcissus.}

THE "Shui Sin Far," or Water Fairy 1 Flower, Joss Flower, or Flower of the Gods, etc, as it is called by the Celestials, is
a variety of Narcissus bearing in lavish proa variety of Narcissus bearing in lavish pro-
fusion chaste flowers of silvery-white, with golden-yellow cups. They are of exquisite beauty and entrancing perfume. It is grown by the Chinese, according to their ancient custom, to herald the advent of their new year, and as a symbol of good luck. The bulbs are grown by a method known only to themselves, whereby they attain great size and vitality, insuring luxurious growth and immense spikes of flowers. In fact, the incredibly short time required to bring the bulbs into bloom (four to six week. after planting) is one of the wonders of na ture, "You can almost see them grow", succeeding almost every where and with everybody. They do well in pots of earth, but rre more novel and beautiful grown in shal. low bowls of water, with enough fancy pebles to prevent them from toppling over Then in bloom. A dozen bulbs started at intervals will give a succession of flowers lisoughout the Winter. We are importing lirect from China immense bulbs of the true arge-flowering variety. Price, 15 cents ach; four for 50 cents.

\section{Giant Golden Sacred Lily.}

The flowers of this beautiful Sacred Lily are almost identical with the Chinese variety, except that they are of the most lovely shade of deep golden-yellow, making a fine contrast with the white bloom of that noted kind. The bulbs are not nearly so large, but the trusses of flowers are of good size, making this a charming bulb for house cul ture. Grows in water like the old variety. Price, 5 cents each; six for 20 cents; 35 cents per dozen. Try a dozen and be delighted.

\section{JONQUILS.}

Much prized for their charming, large, golden and deliciously sweet-scented flowers, perfectly hardy and flow. exing very early in the Spring, also admirably adapted for Winter flowering in the house. Three to six bulbs in a four or five inch pot.

Ddorus, Single.-A bright yellow perianth, deeply lobed and very fragrant. Price, 2 cents each; 20 cents pe: dozen.

Ddorus, Double,-Flowers full, double, and of a golder. yellow color. Fragrant. Price, 5 cents each; 50 cenţs per dozen.

Campernelles. -The best of the Jonquil section. Perianth six-lobed, spreading, and of a light yellow color. Price, 3 cents each; 30 cents per dozen,

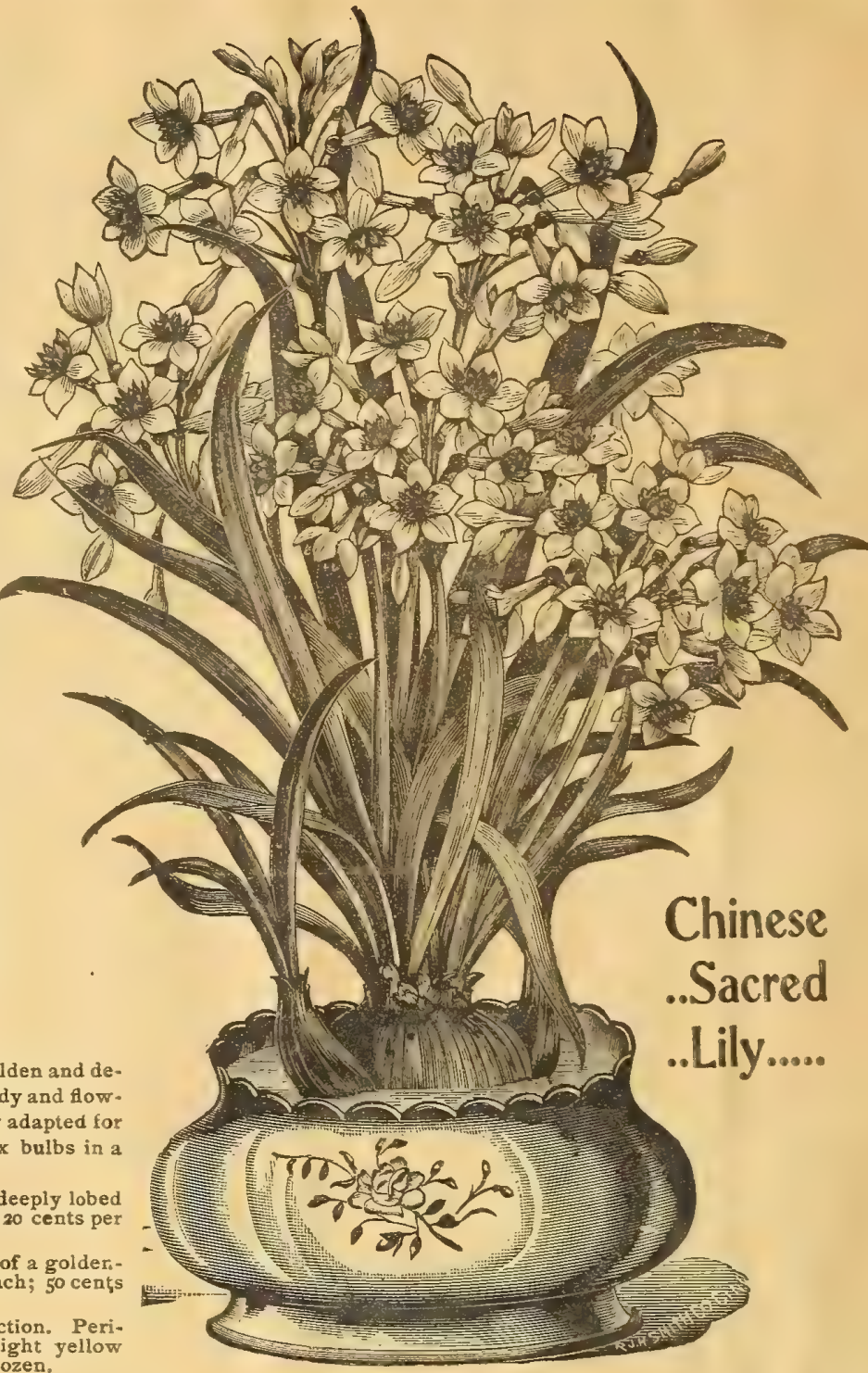

AMARYLLIS JOHNSONII.

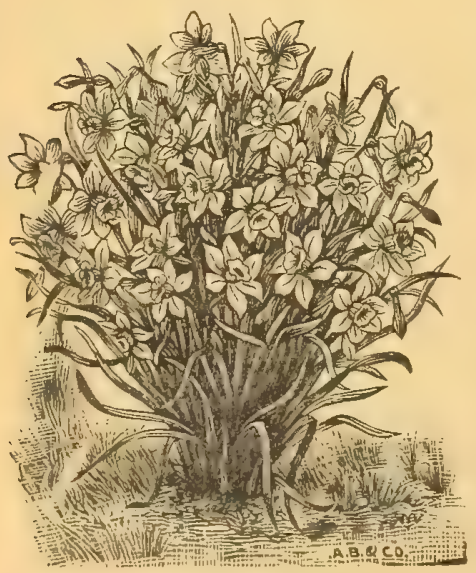

These lovely bulbous plants for Winter or early Spring blooming. Give plenty of water while growing. When through blooming, gradually withhold water, so that They may become dormant during the Summer. Start again in the $\mathrm{F}$ all by repotting in fresh soil and increasing the supply of water gradually. This is the large crimson variety that is very popular, immense lily-like flowers of deep crimson, borne on strong stalks of from five to eight flowers, Very desirable. Price, fine bulbs, 50 cents each.

\section{AMARYLLIS STERNBERGIA LUTEA}

Yellow Star Flower or Fall Daffodils.

This is a popular and valuable bulbous plant on account of its yellow flower being produced in Autumn. Of easy culture, Hardy, when planted six inches deep. Be sure and try a few of this charming plant. Price, 15 cents each; four for go cents,

\section{MY GUARANTEE}

That all plants $I$ ship shall reach their destination in growing condition at any season of the year. Send your remittance by Postoffice Order, Registered Letter, New York Draft or Express Money Order. When you send stamps let them be one-cent stamps, if possible, but please do not send stamps except for fractions of a dollar. I pay the postage on all orders that go by mail.

GIANT GOLDEN SACRED LILY. 
BYACINTHUS CANDICANS.

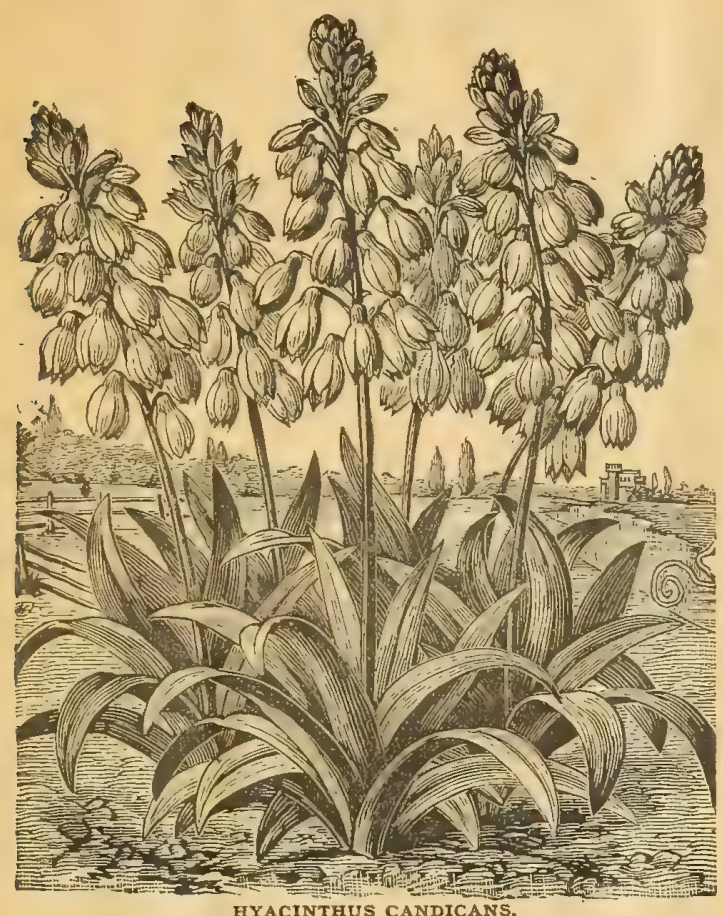

This is not unlike my Spring-blooming Hyacinths. Its leaves are deep green, fleshy, resembling some of the Yuccas. The flowers are white, in handsome, pendulous bells, arranged on pyramidal spikes, often reaching to the height of three feet or more in strong plants. A strong bulb will give from two to three flower spikes, and these produce from thirty to fifty flow ers. The plants come into bloom in July, and bloom continously until October. It is hardy. Price, 10 cents each; three for $25 \mathrm{cts}$.
TRITILEA UNIFOLIA.

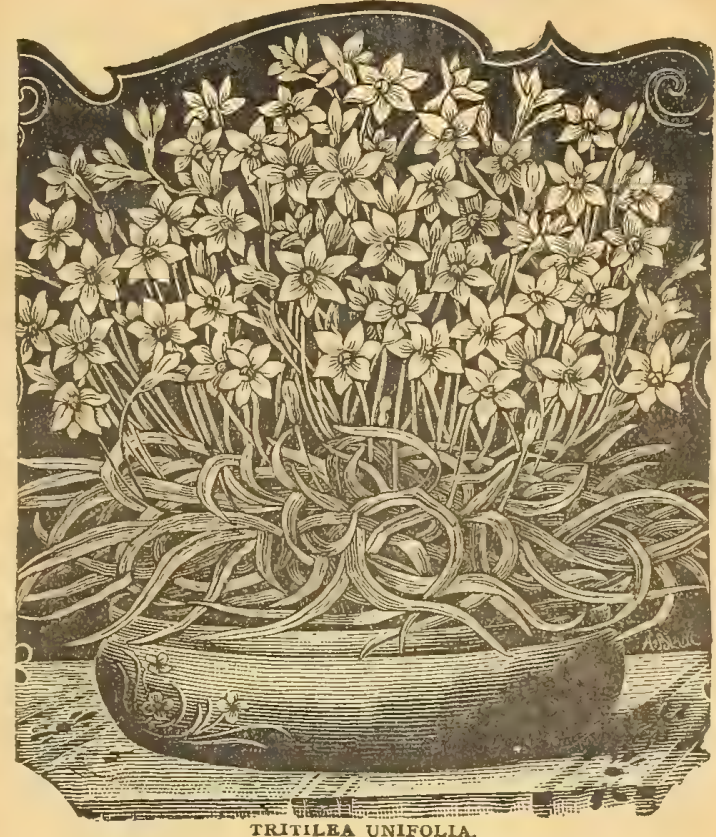

This is one of the choicest additions to Winter-fowering bulbs that has been offered in many years. The bulbs are small, and several can be planted in a pot, each one of which will send up several flower scapes, bearing star-shaped blossoms one inch in diameter, pure white, elegantiy lined with celestial blue. As the fore fading, a pot of these bulbs is never without flowers for several months in mid-Winter. They are also quite hardy, and can be planted in the open ground, where they will bloom elegantly in the early Spring. It easiest culture, and always sure to thrive. Price, fine bulbs, 4 cents each; three for ro cents; twelve for 35 cents.

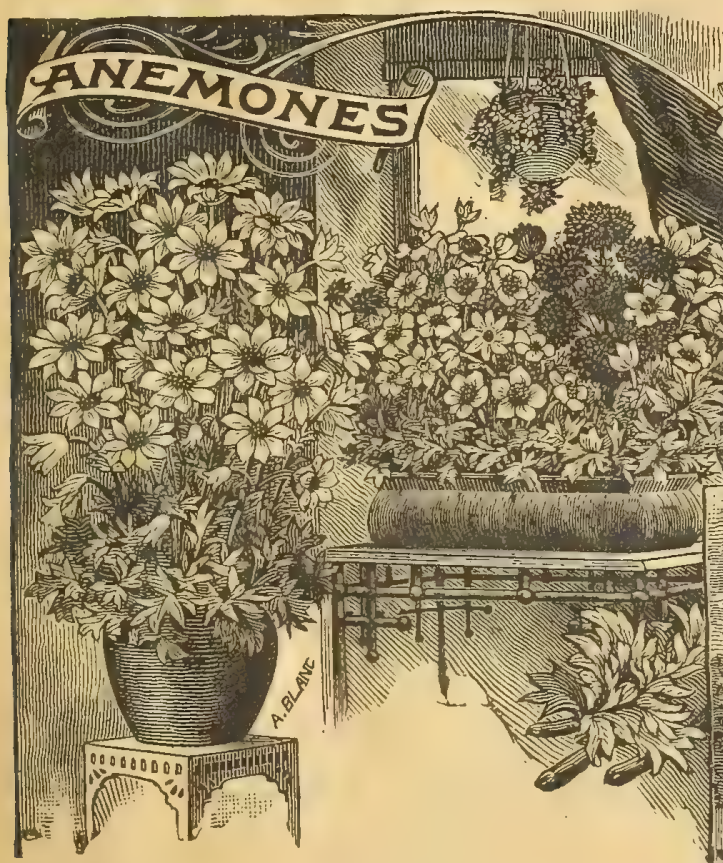

ANEMONES are pery beautiful and brilliant Spring flowering bulbs, which should be found in all gardens, They possess a blue, rose, striped, carnation, etc. For pot culture they are very

fine indeed, and succed best if left in the same pot year after year without removing or disturbing.
Single.-All colors, mixed. Price, 3 cents each; six for 15 cents. Double. - All colors, mixed. Price, 4 cents each; twelve for 40 cts. 


\section{Lilies for Fall Planting.}

\section{LILIUM CANDIDUM.}

The oldefashioned pure white Garden Lily, also known as Easter Lily and Annunciation Lily. One of the hardiest. Flow ers snow white, with heavy yellow stamens and sweetest fragrance. It bears from five to twenty blossoms, This is the most decided variety I have in expressing its preference for the most ing time. It must be planted in the early autumn to succeed well, as it makes its leaf growth at once after planting, and pre well, as it makes its leaf growth at once after planting, and prepares itself for early flowering. The bulbs are sometimes kept in cold storage for Spring sales, but never do quite so well. The prices are lower than for many years, and bulbs very fine. Cuspermanent bed or border. Ready now. Price, 20 cents each; three bulbs for 50 cents; \$1.50 per dozen.

The True Bermuda Easter Lily,

\section{LILIUM HARRISII.}

"The fairest of all things that blossom and grow,

Sweet as the Summer and pure as the snow.

Is the Lily that tells

Like the glad Easter bells,

Once more the sweet story which all hearts should know."

This peerless Lily is the greatest acquisition to floriculture made in many years. Their profusion of bloom, the remarkably short time required to bring them into flower, and the certainty to produce abundant bloom and also the ease with which they can be manipulated to be flowered at any desired period, such as Christmas, Easter and other special occasions, render them invaluable. The flowers are delightfully fragrant, pure waxywhite, of great substance, and if cut as soon as they are open, or partially open, they can be kept for two weeks. A short time anly is required to bring them into bloom. Bulbs potted in Auonly is required to bring them into bloom. Bulbs potted in Auof bloom can be keot up from November until May by bringing the pots of rooted bulbs in from cold frames at intervals through the pots of rooted bulbs in from cold frames at intervals throughout the Winter. The quantity of bloom produced is marvelous, the average production of bulbs five to seven inches in circum- bulbs seven to nine inches, eight to twelve flowers; and if desired, a second crop of flowers, frequently equal to the first, san be secured the same season by drying the plants off after bloom. ing for a time and then again starting them. Blooming plants in pots form typical Easter offerings and presents, for decoration of the window, $t, 3$ ble, house or church. of the window, $t a b l e$, house or church. Nothing is more appropriately beautiful and highly appreciated. Thousands upon thousands are sold in the large cities every Winter for this purpose. As a garden Lily it is of great beauty, being entirely hardy excepting in northern climates, where it requires a protection of leaves or litter to the depth of five or six inches. Price, 15 cents each; four for 50 cents. Larger bulbs, 20 cents each? three for 50 cents. Extra large, 50 cents each, or three for \$1.25.

\section{LILIUM AURATUM.}

The Gold-Banded Lily of Japan.

This is the highest type of flowering buibous plants, the most beautiful and fragrant of all our list. The flowers are of immense size, being fully twice as large as those of almost any other Lily. There is wonderful beauty in the growth of this gorgeous flower; first, the dry, scaly bulb, then the sturdy stalk pushing through the earth, next the dark green leaves and fiow er buds, and rinally the dazzlıng white and gold blossom. The new bulbs are brought from Jipan for us each year, and only such will give best results. They are shipped to us wrapped in a ball of clay, and arrive plump and sound, every one ready to bloom. Price, fine bulbs, 20 cents each; three for 50 cents; $\$ 1.75$ per dozen, postpaid.

Lancefolinm Album.-This is one of the most beautiful of all Lilies. Pure white and very fragrant. Price, 20 cents each. Longifoliam Japonicum.-The finest-flowering of all Lilies.

Pure white, spotted scarlet, very showy. Price, 20 cents each.

Thunbergian Aureum.-This is the lovely Kikak Lily so much in favor with the Japanese. The richest-colored of all Lilies. Price, 20 cents each.

Tigrinum Flora Plena,-Bright orange, spotted black, and very double. Price, 25 cents each; three for 60 cents.

Speciosum Rabrum.-A beautiful bright rose, spotted with a rich, velvety-crimson. Price, 25 cents each; three for 60 cents.

\section{The Set of eight lovely Lilies, all distinct, costing \$1.70, sent for only \$1.25.}

\section{THIS IS A GREAT OFFER.}

Lily Harrisii is ready now. The other varieties and Lily of the Valley cannot be sent until November. Order now, and we will file your order and send as soon as we receive them from abroad.

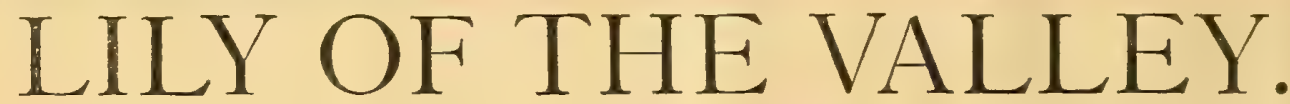

The Lily of the Valley is one of the most useful and greatly admired plants grown. The modest bell-shaped flowers of purest white are highly prized for cutting purposes, and for lowering in pots in the Winter they are exceedingly well adapted. Beautiful and most interesting ornamental designs for the parlor or conservatory may be produced by planting the Lily Crowns in Crocus pots or in pyramidal pots made especially for this purpose, and pierced with holes. They will last several weeks in beauty. By taking them in at intervals a succession of differ ent designs may be kept up all Winter. They are also forced in immense quantities by florists, but they are the most charming when grown in large patches, in partially shaded localities around the lawn, near the borders of streams, lakes, etc., being perfectly hardy.

Price, i cents each; 30 cents per dozer.

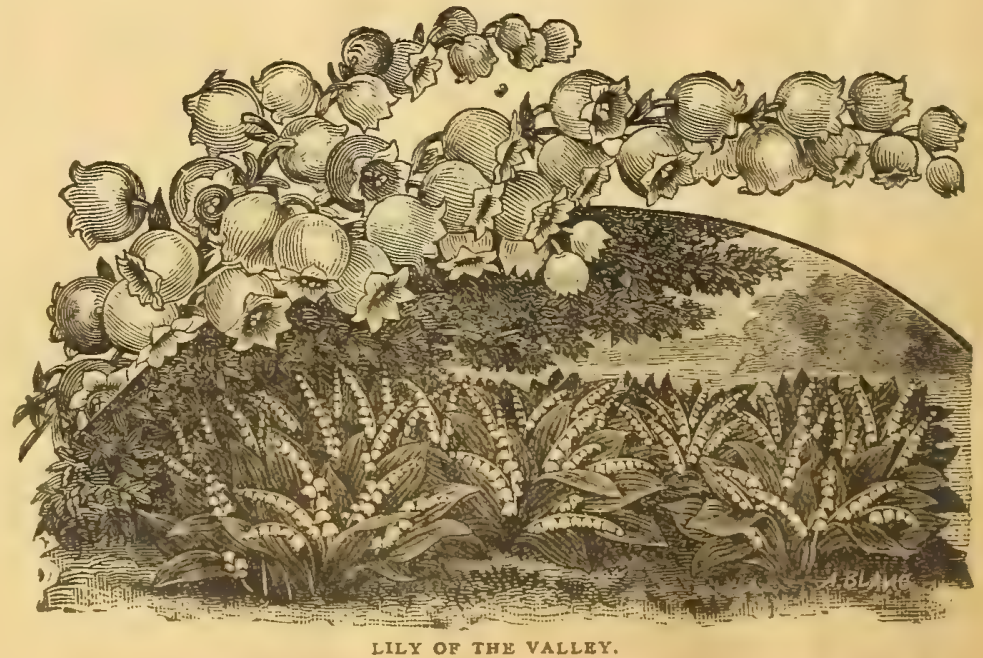


Miss Ella V. Baines, The Woman Florist, Springfield, Ohio.

FLORAL FIRE-CRACKER. Brodiæa Coccinea.

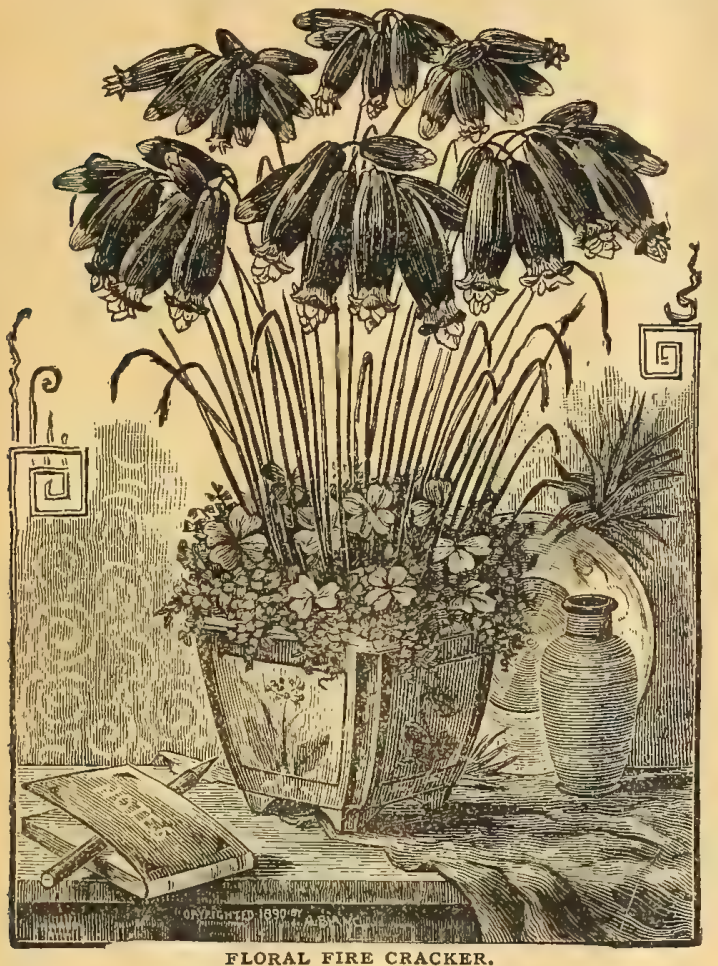

This beautiful and interesting Winter-blooming bulb is a sort of Brodiza, but entirely unlike any other variety in both form and color. It is a striking beauty, and one that catches every eye, Its blooms are borne in clusters at the end of long, slender stems, and droop like a Fuchsia. They are two or three inches in length, of a deep, bright crimson-scarlet color, tipped with green and white. It is among the easiest of all bulbs to grow, and it is sure to succeed and bloom elegantly with any one. Pot the bulbs at any time during the Fall, and treat them as recommended on leafiet accompanying each order. er my friends will find a most beautiful and novel thing, and unlike anything you have ever grown or seen. Price, fine bulbs, 5 cents each; six for 25 cents.

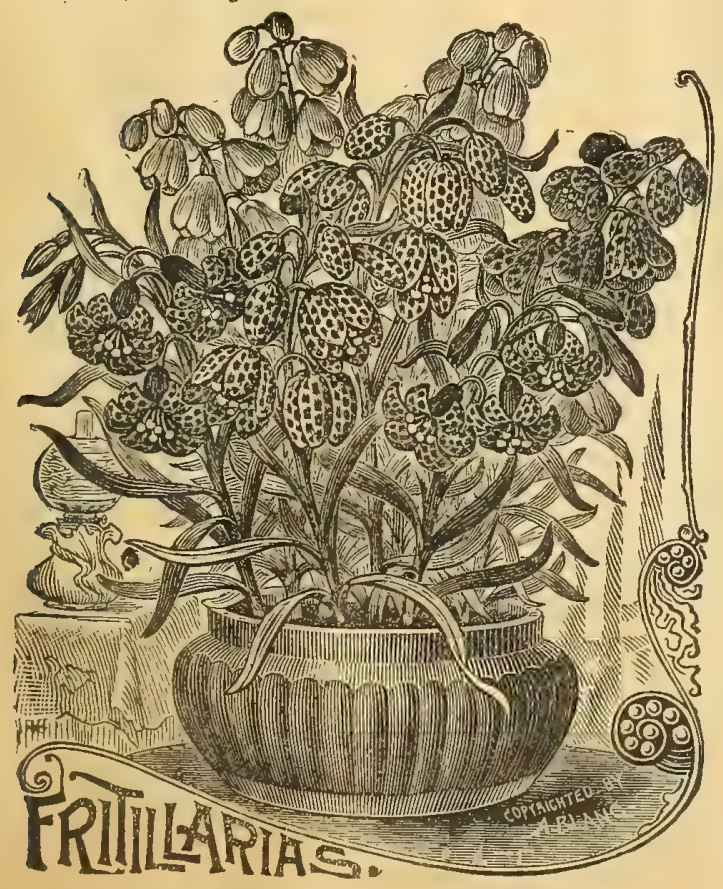

\section{Fritillaria Meleagris.}

(Suake Head, or Turk's Cap.)

Very early flowering bulbs, suitable either for garden or pot culture In pots they bloom during January or February, and culture. In pots they bloom during January or February, and on graceful, drooping stems; an attractive object to any one's garden or window. Price, for assorted colors, ro cents each; three for 25 cents.

\section{FRITILLARIA IMPERIALIS.}

\section{(Crown Imperials.)}

Well known bulbs of large size, producing an umbel of bell. shaped flowers of various colors early in the Spring. They are entirely hardy, and are very showy.

Mixed Colors.-Yellow, red, orange, etc. Price, 25 cents each.

\section{RANUNCULUS,}

This class of bulbous plants is among the finest of all flowers. The French Ranunculus especially are distunguished by great strength, size and beauty. They attain a height of from ten to fifteen inches, and the hues and colors of their many varieties, varying from pure white and yellow to bright vermilion and crimson, are really beautiful. The Persian Ranunculus are a little smaller than the French, and also more dwarf. However, their colors are as fine, and exhibit the most beautiful shades, and are of the most graceful form. The Turban, or Turkish Ranunculus differ very much from each other, and display lovely Oriental beauty of coloring. Can be grown easily in pots, or out of doors if protected.

Persian Rananculus. - Price, 3 cents each; 30 cents per dozen. Turkish Ranunculus.-Price, 3 cents each; 30 cents per dozen. French Ranunculus.-Price, 4 cents each; 40 cents per dozen.

\section{IRIS. Flowering Flag.}

\author{
(F1eur-de-Lis.)
}

The Iris are fast coming into favor. They are entirely hardy, and increase rapidly when planted in the flower garden. They should be planted in the Fall.

Iris, Susiana,-If every lover of flowers could see this grand plant in bloom I really believe not one in one hundred would refuse to pay one dollar each for one or more bulbs of it Among all flowers there is hardly one of such oddity and striking beauty. The bloom is of enormous size, and in describing it I say " it is chocolate and black mottled, beautifully veined with grayishwhite," yet from this no one can form a correct idea of how the plant idea of how the plant looks, It is indescribabe surprised when he be surprised when he sees it. It is perfectly hardy, and blooms in May. In July the foliage dies down, and the bulbs Fall or the next Spring. Try it, and when it blooms you will undoubtedly pronounce it the

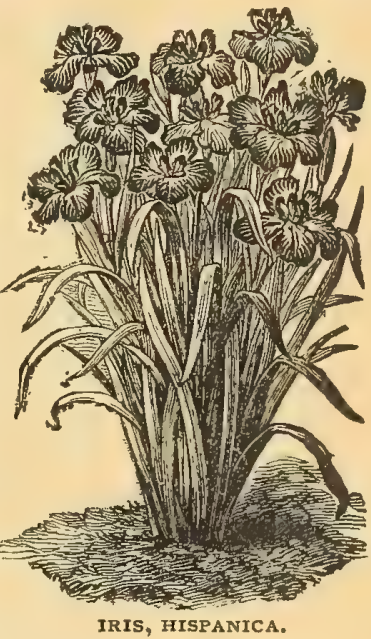
Price, 25 cents each; three for 60 cents.

Iris, Hispanica.-(Spanish Iris.) The Spanish Iris are grown in England by the millions for cut flowers. Perfectly hardy. They are very recommendable. The colors and shape of the flowers resemble the most beautiful Orchids. The colors are very striking, while the substance of the flower is much more permanent than the other varieties of Iris, causing them to permanent than the other varieties of Iris, causing them to Iris. golden-yellow. Price, 3 cents each; six for 15 cents; 40 cents per dozen; $\$ 2.00$ per hundred.

Iris, Pavonia.-(Peacock Iris.) This beautiful Iris is very attractive. It is a sky-blue color, with a peacock eye of dark blue on each of the petals. It certainly is a gem. Price, 5 cents each; six for 25 cents.

NOTE.-The Iris are perfectly hardy, 'and should be planted in the Fall for Spring blooming. Every bullo will flower the first year with the exception of Iris Susiana, which is shy in bloom until well established. 


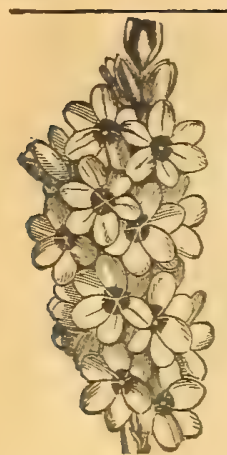

2xis.

\section{THE BEAUTIFUL IXIAS.}

HE Ixias produce their beautiful flowers in spikes and are of the most dazzling and brilliant colors, and sure to attract great attention. It is only a few years that they have been grown in this country to any extent, but in that time, like the Freesia, they have become very popular. For pot culture in the house they
give great satisfaction, being of easy calture and free bloomers. Half a dozen bulbs can be planted in

five-inch pot, and the display will be mag-
nificent. For open ground culture give them Winter protection with leaves or straw. They are very cheap, and all lovers of odd and beautiful fowers should certainly add them to their collec. tion. The sorts I offer are new and very fine. Price, good plants, 3 cents each; six for I5 cents; 25 Allium Neapolitanum. Allrum Neapolitanum and Tritilea Unifolia are a splendid comThis plant has graceful leaves from eight inches to a foot long, of the darkest green, forming a very cheerful mass. Each plant bears from one to three scapes, fourth of an inch in diameter. Many of the trusses bear over one hundred flowers each. Price, 3 cents each; 30 cents per dozen.

\section{Freesia Refracta Alba,}

No description can do adequate justice to this beauti. ful plant. The flowers are two incheslong and about the same in width, shaped like miniature Gladioli, and borne in clusters of six to ten on depressed horizontal scapes. The bocy of the fower is pure white, with most delicious, being a mixture of Mignonette, Violet and Japanese, and one plant is sufficient to perfume a large room, without the overbearing perfume of Hyacinths or Tuberoses. The plant has tooth-shaped bulbs and flat, spreading leaves. Its cultivation is of the simplest, requiring only to be potted in October, to be watered sparingly at first, placed in a sunny window watered sparingly at first, placed in a sunny window flower, store in some place and repot at proper season in fresh soil for another year's growth. Price, 3 cents each; six fine bulbs for 15 cents; twelve for 25 cents.

$$
\rightarrow \text { OXXAIS. }
$$

These varieties of Oxalis are all Winter-blooming. They make the most beautiful hanging pots and baskets, producing a mass of flowers all Winter, which in brilliant and beautiful colors are truly charm. ing. Winter-blooming Oxalis are always sure to please. Plant five or six bulbs in a six-inch pot. They commence growth immediately after planting. Our mixture embraces pink, white, yellow, red, etc. Price, for a mixture of all colors, 3 cents each; 30 cents per dozen. 0xslis Ceruns Flora Plens, - The double flowered yellow Oxalis.

\section{Very desirable. Price, 5 cents each, siz for 25 cents.}

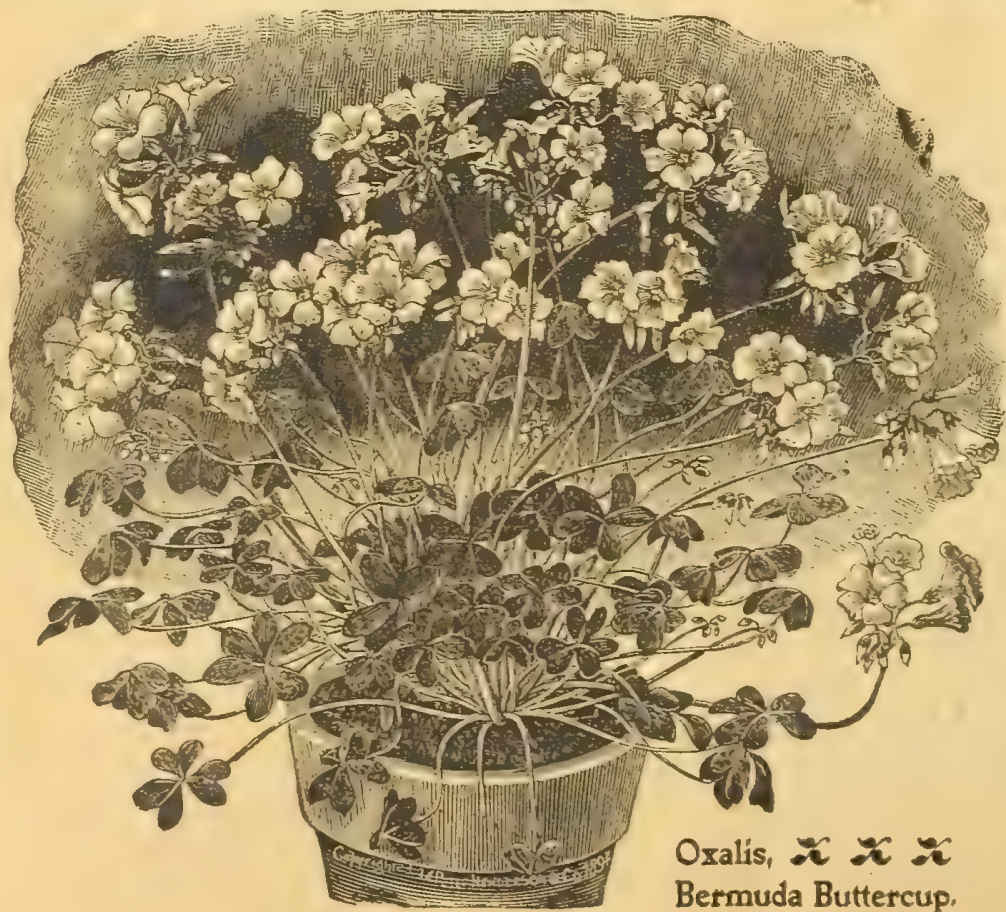

\section{BERMUDA} BUTTERCUP OXALIS.

An unrivaled Winter:

Flowering Pot Plaut.

This is one of the finest Winter-flow. ering plants for pot cuiture that I have ever seen. It is such a strong, luxuriant grower that one bulb will be sufficient for a six or eight-inch pot. Place in 2 dark, cool position for a few weeks to root thoroughly, and remove to a sunnt situation in the window or conservatory, in a temperature of about sixty degrees in a temperature of about sixty degrees Fahrenheit, and the great profusion of bloom produced in uninterrupted abundance for weeks will astonish and delight you. Flowers of the purest bright buttercup yellow. Well grown plants have produced as high as seventy flower stems at one time, and over one thou-
sand flowers in one season. The flowers, and frequently the leaves, fold up at night and open again the next morning but when grown in a partially shaded situation the flowers remain open all the time. Properiy treated, the plants will fower in six weeks from the time the bulbs are planted. I do not clain the Bermuda Buttercup Oxalis to be strictly a new plant, but a greatly improved selection from Oxalis Ceruna. grown in the congenial soil and climate of Bermuda until the balbs have at tained great strength, producing buibs, plants and flowers larger and more luxuriant in all parts than the type. Excels all bulbous plants in profusion o bloom. It is graceful, and delights all who see it. Price, 6 cents each; 60 cents per dozen. 


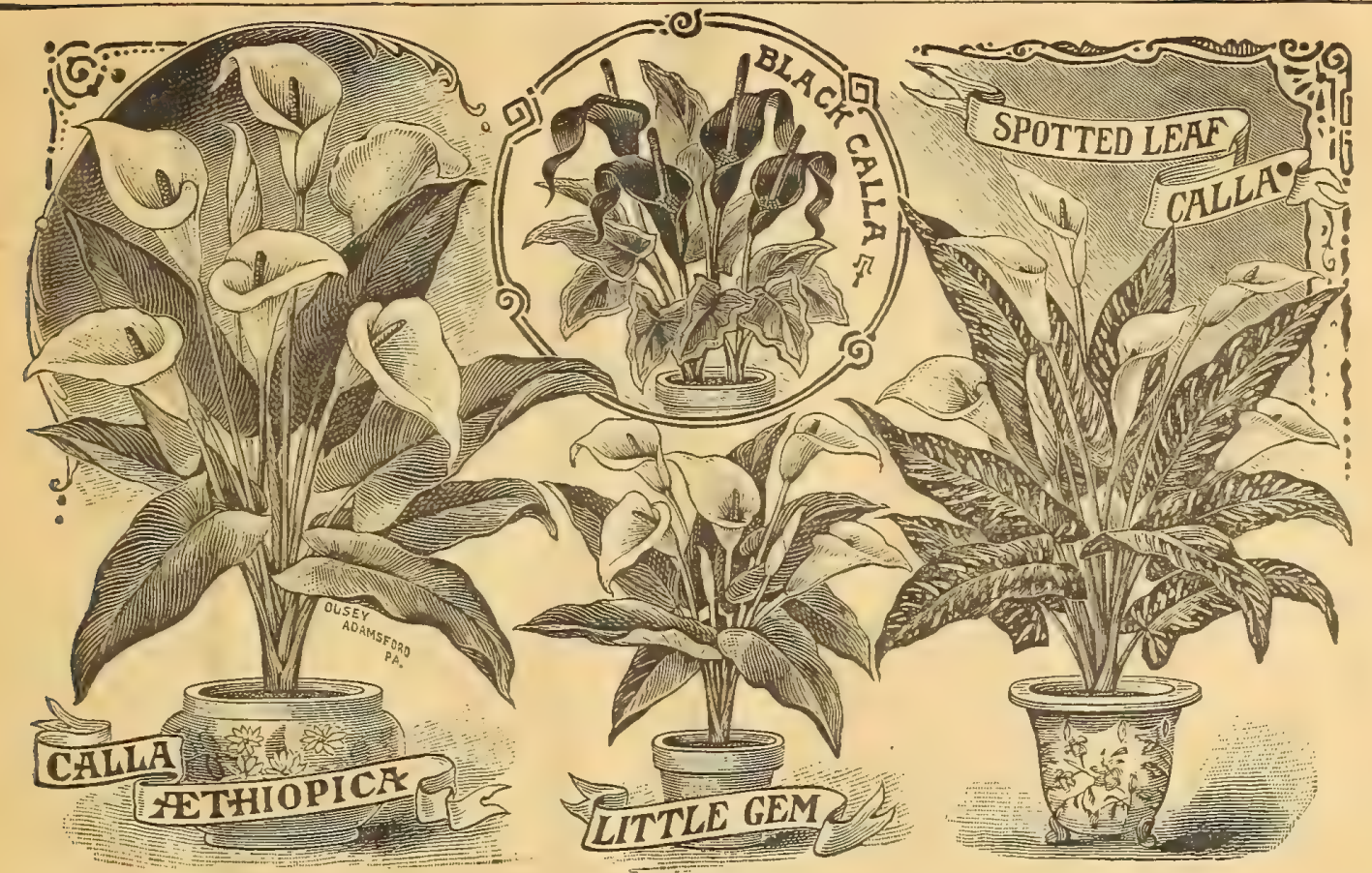

\section{Calla Lilies.}

Bvery one weeds a Calla for Winter bloom. Here are the best.

The Dwarf Calla.-Grows ten to fifteen inches high, and produces

many blooms.' Price, 25 cents each.
Calla Ethiopica.-The old-fashioned sort. In three sizes. Price, small bulbs that will bloom, io cents each; large bulbs, 25 cents each; extra large bulbs, 50 cents each.

Black Calla,-(Arum Sanctum.) A freak of nature, and very odd. Price, 35 cents each

Tellon Calla, Hastats.-Lovely yellow flowers. This is becoming quite popular, Price, fine bulbs, 50 cents each.

SPECIAL OFFER - The set of four distinct Callas for $\$ 1.00$.

\section{BULBOCODIUM VERNUM.}

A very pretty bulbous plant. Much resembling the Crocus. They multiply rapidly from offsets. It. is a good plan to take them up and divide them every third year. Few plants prove more welcome in the garden in February than Bulbocodium Vernum, either in beds, patches, or masses. The flower is funael-shaped, and produces two or three from each bulb. The color is violet-purple, with a white spot on each claw. Very desirable. Price, 10 cents each; three for 25 cents.

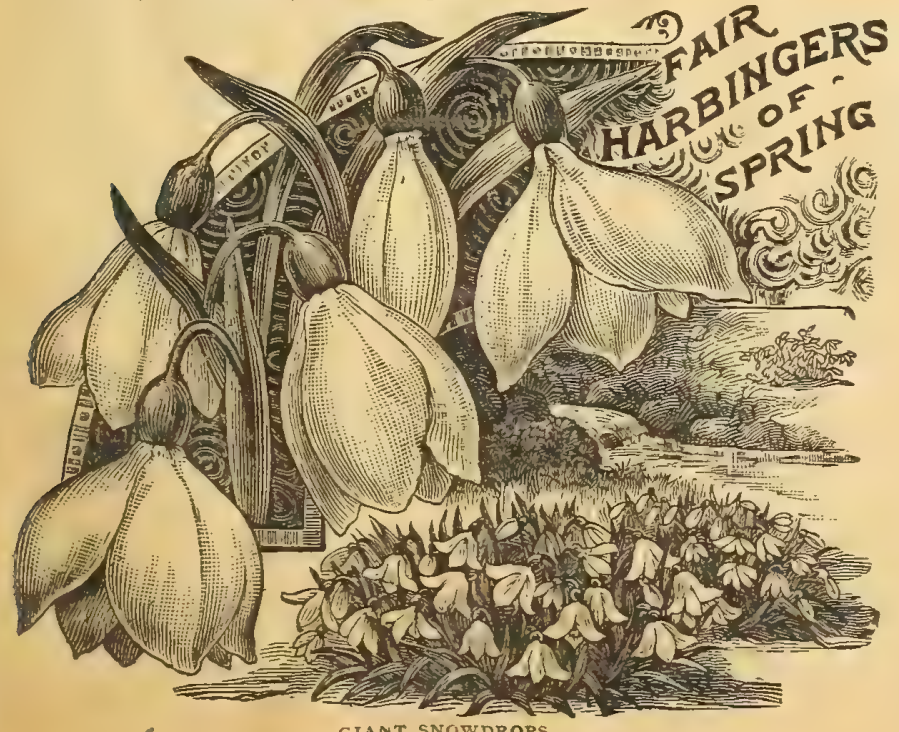

ERANTHIS HYEMALIS. WINTER ACONITE.

These plants, from their very early flowering habit, are extensively grown, and are very desirable. Perfectly hardy. Planted in the Fall they are among the earliest of blooming bulbs. The flowers are pure yellow. Price, 15 cents each; two for 25 cents,

\section{Giant Snowdrops.}

Beautiful, $d$ warf, white flowers, pushing up through the snow in the Spring, a habit from which arose this name. They are lovely little blossoms, and should be found in every garden. In doors they are equally pretty, and easily brought into bloom. Being dwarf, they are usually planted along waiks or the mar gin of beds. The Giant Snowdrops I offer are much superior to the common varieties, producing larger flowers.

Giant Single Snowdrop.-Price, 2 cents each; 20 cents per dozen. Giant Double snowdrop.-Price, 3 cents each; 30 cents per dozen.

\section{Chionodoxa Lucilliæ.}

\section{(GLORY OF THE SNOW.)}

One of the most lovely flowering Sprfing bulbous plants ever introduced, producing spikes of lovely azure-blue flowers, with pure white centers. It is one of the earliest of all flowers, blooming before the Crocus, and sure to be more than satisf actory to to those. who plant it. For Winter-blooming this bulb is also lovely. Price, strong home-grow

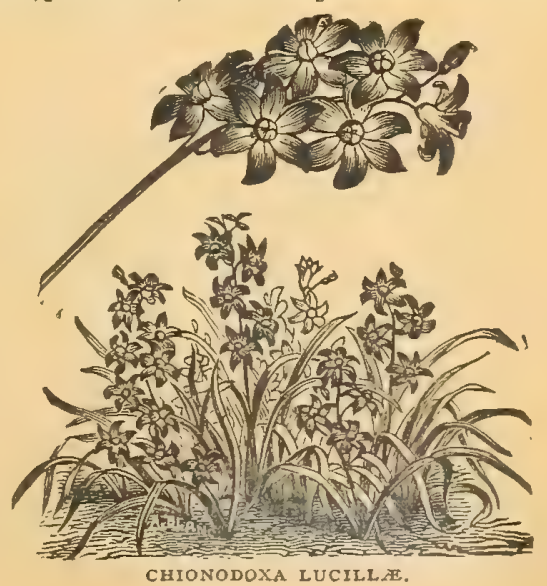




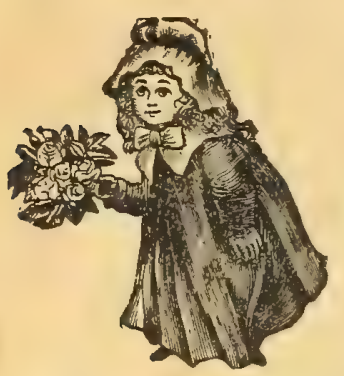

"I have a bouquet of Roses which were picked from that 'IMPERIaL' Collection of Rose plants mamma bought from Hiss Wlia V. Baines, The Woman Florist, last Fall. They grew and bloomed beautifully. W had Roses all the Summer,"

\section{MISS ELLA V. BAINES'}

"IMPERIAL" COLLECTION OF

EVER-BLOOMING ROSES.

No such bargain has ever been offered by any firm. Just to think? I mail you for the small suth of fifty cents twelve of the choicest Winter-blooming Roses. You can see just what varieties you are getting. The Roses in this "IMPERIAL" Collection wil all bloom this winter in the house or next Summer in the yard. Every one is a beauty. I guarantee these Roses to be as good plants as any firm in this country sells for ten or twenty cents each. It will cost you such a small sum to prove this, that none should fail to avail themselves of such a liberal offer. Price, large two-year-old plants of any of these Roses, 25 cents each; five for $\$ 1.00$. Any twelve for $\$ 2.00$.

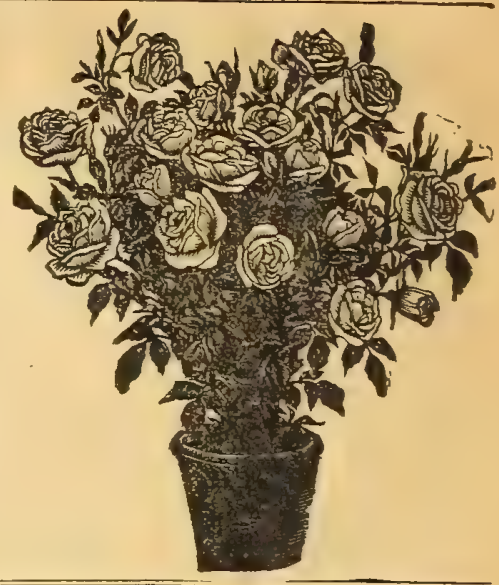

\section{Innperial Collection.}

THESE VARIETIES ARE TEE VERY BEST FOR WINTERBLOOMING OR FOR FALL PLANTING IN THE YARD.

Marie Van Houtte, - This is one of the prettiest and sweetest of all Roses. Of a faultless straw-yellow color, outer petals washed with bright rosy-crimson.

Hadame Abel de Chatenay.-This Rose is of the Testout family, which it resembles very much in habit of grow th and flow. ers, which are of a deep rose color. Large and handsome, and very fragrant. Fast becoming popular.

Marion Dingee.-Deep, brilliant crimson. One of the darkest, if not the very darkest, richest-colored Tea Rose in existence.

Madame Lambard.-A strong-growing variety, with large, handsome buds and flowers of the richest hue. Deep rose, flushed with brightest red, reverse of petals pink. Its worth is being fast demonstrated

Monsieur Furtado. - This is claimed by sorne rosarians to be the very best yellow Tea Rose. The buds and flowers are very double, and it makes a handsome bush.
Queen's Scarlet.-The freest-blooming of all red Roses. The color is velvety-crimson. Entirely hardy.

White La France, -Identical with La France, except in the color of its flowers, which are pure white, sometimes shaded with delicate fawn

La France. - This is everybody's favorite Rose. A peach-colored pink variety that is hardy. Deliciously fragrant.

The Queen. - This is the hardiest of all the white Roses belonging to the Tea varieties of Roses. It is a beauty.

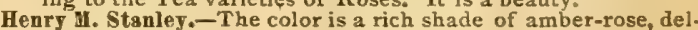
icately tinged with apricot-yellow towards the center. Very desirable.

Burbank.-Color clear pink. This is claimed to be an improved Hermosa, which is sayıng a great deal for it. Hardy.

Dake of York.-Flowers vary between rosy-pink and white, tipped with red. It is a very showy and handsome variety.

\section{"HOLDDAY" CII
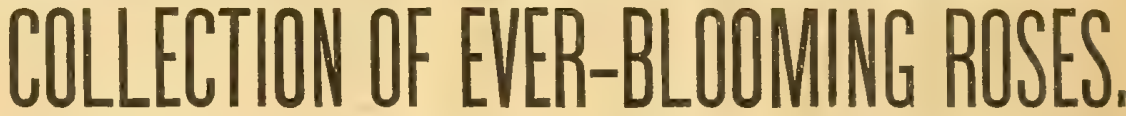

I have made a selection of the very best Roses for Winter blooming, embracing a wide range of color. I commend this colleetion to all who desire to grow Roses in the house during Winter. I have seen all these Roses in bloom during the Holidays, and continuing right through to Easter time.

Bon silene.-Deep Rose, illumed with bright red. A grand | Bridesmaid.-This is a fit companion for the Bride. It is also Winter bloomer. Very sweet.

Isabella Sprunt.-Flowers treely during the Winter. Flowers of the richest yellow color.

The Bride,-The best Winter-blooming white Rose. Planted by the million by growers of cut flowers. None finer. planted by the million for Winter-blooming. The best deep pink Rose for this purpose.

Papa Gontier.-Deep red. Very free and very sweet.

Sofrano.-The old standby for a Winter bloomer. Lovely saffron-colored buds of the most delicious fragrance.

Price for the collection of six choice "Christmas" blooming Roses, only 40 cents; 1arge two-year-old platts, 30 ceuts each, or the six for $\$ 1.20$.

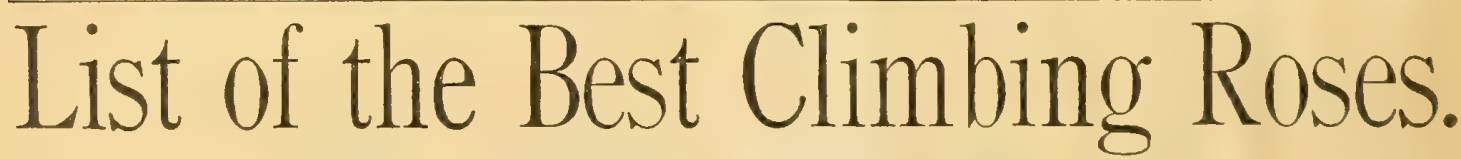

PRICE, 10 CENTS EACH; SIX FOR 50 CENTS.

LARGE TWO-YEAR-OLD PLANTS, 35 CENTS EACH, EXCEPT WHERE NOTED.

Alister Stella Gray.-(Golden Rambler.) This is a grand Rose. I like it better than Yellow Rambler (Aglia), although not quite so hardy.

Bardou Job. - The richest-colored of all Roses. Deep, velvetycrimson, almost black. Semi-double, Very handsome.

Climbing Perle des Jardins.-Deep golden-yellow

Climbing Wootton,-Deep, rich red. Fragrant.

Climbing Meteor.-Rich velvety-crimson. Extra fine. Hardy.

Climbing Malmaison,-A lovely flesh color. Strong grower.

Climbing La France,-A beautiful peach-pink color of delicate shades, Hardy.

Crimson Rambler.-This is the wonder of the age. No Rose will cause you more pleasure. Astonishes everybody who

sees it. Bright scarlet in immense panicles of fifty or more blooms. Magnificent. Hardy.

Cloth of 6old.-Clear golden-yellow.

Empress of Chins,-Beautiful clear pink. Hardy.
Gloire de Dijon, - A charming Rose, with a blending of amber, yellow and pink. Price, two-year-old plants, 5o cents each. Marechal Niel-Everybody's favorite. Deep golden-yellow. Very fragrant. Price, two-year-old plants, 50 cents each. Hary Mary Washington.-Pure white, in large clusters, Hardy, Pink Rambler.-New, Deep, rich pink. Very handsom Reine Il arie Henrietta, - Cherry-red. Sweet-scented.
White Rambler, - Pure white. An elegant Rose. Hardy. Waltham Queen.-Rich, red flowers of magnificent size. W. A. Richardson.-Orange-yellow. Coppery shades.

White Marechal Niel.-Same as Marechal Niel, except that the howers are creamy-white, Very desirable. Price, two-yearold plants, 50 cents each.

Yellow Rambler. - This comes next to Crimson Rambler for beauty. It is the only hardy climbing yellow Rose. Cannot be praised too highly. Hardy.

Zolia Pradel.-Pure white. Full and sweet. 

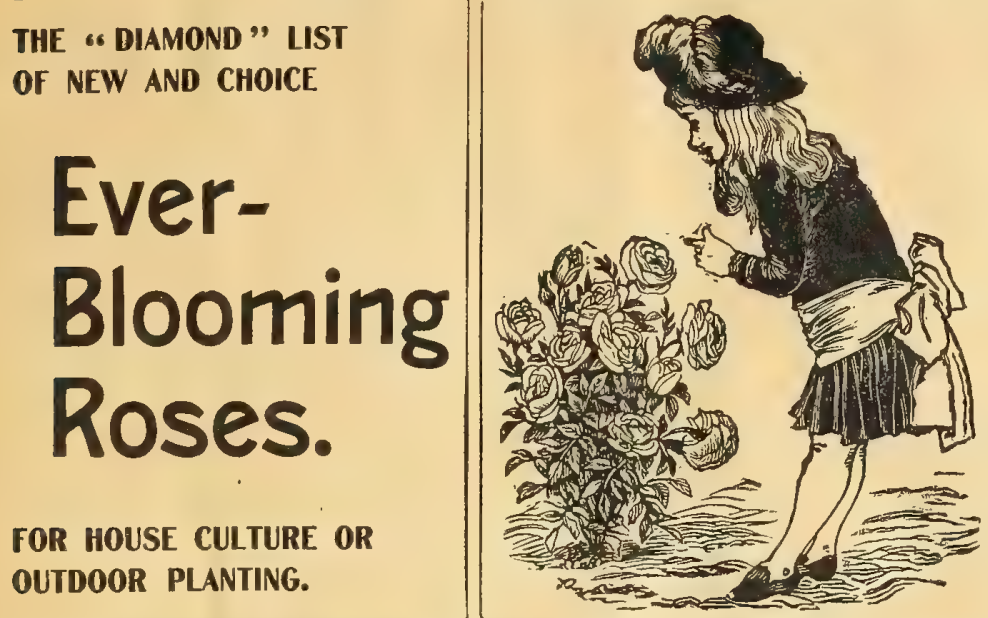

I have taken great pains to cull from this list Roses of no special value. My customers can rely on the Roses in this list to be the best of the old and new varieties of Ever-bloomers.

Price, 10 cents each; any six, of your own selection, for 50 cents; any fifteen for \$1.00. Large two-year-old Roses, from this list, 25 cents each, or five for $\$ 1.00$.

Admiral Dewey.-(New.). Light shade of lovely pink. American Beanty. - A universally admired rich red Rose. Augustine Halem.-Bright rosy-red. Very sweet.

Bridesmaid.-The loveliest of all pink Roses.

Beaute luconstante. - A Rose that changes its coler from yellow to crimson.

Besnty of Stapleford.-Bright pink and rich rosy-crimson.

Belle Seibrecht.-One of the loveliest of pink Roses "Of the largest size.

Barbank, - This Rose is claimed to be an improved Hermosa. Color bright pink.

Catherine Ifermet, - One of the most fashionable shades for cut flowers. Color a clear rosy-pink, large.

Comtesse de Frigneuse.-Deep golden-yellow, large and full.

Champion of the World.-A rich, deep, rosy-pink, very free bloomer and deliciously fragrant. Hardy.

Clothilde Soupert. - The best of all Roses. Literally loaded with blooms, pure white, pink center. Very beautiful.

Christine de None.- Color a rich crimson, deeper center.

Crown Princess Victoris,-(White Malmaison.) Pure white.

Coquette de Lyon.-(Yellow Hermosa.) Pure yellow.

Coquetie de lyon.- ( The old favorite white Rose. None better.

Charles Legrady. - Color a fine chamois-red, shaded crimson.

Charles Legrady - Color a fine chamois-red, shaded crimso

Countess Eva Starhemberg.-Rich creamy-white, tinted golden-

yellow.
Clara Watson,-(New.) Salmon-pink. Extremely free in bloom. Dr. Reymont.-Rich velvety-red.

Duchess de Brabant. - This is another old-time favorite.

Duchess of Albany.-(Red La France.) Charming.

Devoniensis.- Magnolia fragrance, creamy-white color.

Dr. Grill.-Coppery-yellow, with tawny reflex.

Duchess of Edinburg.-Large buds of an intense dark crimson.

Dnke of Iork, - Rosy-pink, flushed with white.

Dnke of York.-Rosy-pink, flushed with

Etoile de Lyon,-Deep golden-yellow.

Ernest Hetz. - Color rosy-carmine, deeper in the center.

Enchantress.-(New.) Creamy-white, tinted buff in the cente
Francois Dubreuil.-Deep, vivia crimson. A delightful Rose.

General Robert E. Loe.-Color orange-yellow, shaded white Very rich and beautiful. The best Rose extant.

Grace Darling.-Color porcelain-rose, shaded crimson.

Golden Gate.-Color a rich, creamy-white, beautifully tinged with golden-yellow. A very choice Rose.

Hermosa.-Beautiful pink flowers, borne in clusters.

Henry M. Stanley - A rare shade of amber-rose, delicately tinged with apricot-yellow towards the center.

Helon Cambier.-Salmon-rose and coppery-yellow, A very handsome Rose.

Isabella Sprunt. - An old-time favorite yellow Rose.

J. B. Varronne.-Scarlet-crimson and buff color.

Kaiserin Augusta Victoria.-(New.) Pure white. A superb Rose in every respect. Hardy.

Inciole.-Color bright carmine-rose, shaded yellow.

Letty Coles. - Color a soft, rosy-pink, shaded with crimson.

La France.-Too well known to need description. A favorite.

Lodis Richard.-Coppery-yellow, tinted lilac.

Leonie Osterreith.-(White Soupert.) Pure white. Grand bedder.

Media.-A grand yellow Rose of the largest size.

Miadame Scipion Cochet.-Color a soft primrose-yellow.

Iadame Caroline Testout.-Color a brilliant satiny-rose, deepening to clear red, edged with peach.

Wadame Eli Lambert. - A rich, creamy-white, tinted yellow.

Madsme Hoste.-Long, pointed buds of pure white.

Madame Hoste.-Long, pointed buds of pure

Molmaison.-Creamy-flesh, with rose center.

Madame Pornet Ducher. - Yellow La France.) (New.) Lemon-

yellow.
Mrs. Pierpont Morgan.-(New.) A bright, clear, deep pink. Superb.

Madame Abel Chatenay.-Rosy-red, with darker shadings. Superb.

Madame Etienne.-A grand pink Rose, Known as the C'শarf Mermet.
Madame Honore Defresne.-One of the very best deep yellow

Roses.
Madame Wagram.-(New.) Large, full flowers of magnificent satin-rose color. Extremely beautiful. Mrs, Robert Garrett.-Probably the very best of all brignt pink

Iuriel Graham, - This belongs to the Mermet family. Pale cream, faintly blushed rose.

Madame Welche.- Color amber-vellow and crimson-rose.

Jiarion Dinge日.-Deep, brilliant, dark crimson.

Madame de Watteville.-This is called the Tulip Rose. Color a rosy-blush, mildly bordered with bright crimson.

Mademoiselle Franciska Kruger.-Probably the best all-round bedding Rose I have. Deep coppery-yellow.

Iaman Cochet.-(New.) Don't fail to try this beautiful Rose Color a deep rose-pink, shaded and touched with yellow.

Meteor.-This Rose ranks at the head of all the dark, rich red Roses. None better.

Mrs. Degraw. - The color is a rich, glossy pink. Hardy.

Madame Schwaller.-A deep, rich pink, blooms in clusters of from five to twenty Roses. A great garden Rose.

Mademoiselle Cecile Berthod.-A deep, rich, golden-yellow.

Marie Guillot.-The old standby for a pure white Rose.

Madame Camille.-Remarkable color of salmon.

Niphetos. - A most elegant white Tea Rose, with enormous buds.

Perle des Jardins.-Clear golden-yellow, very rich and beautiful.

Papa Gontier.-Rich, bright red and crimson.

Princess Sagan, - The color is a rich, velvety-crimson.

Pierre Guillot.-This superb Rose has no superior, Always in bloom, buds and flowers of enormous size, of the richest red

Princess Beatrice.-A coppery or ruddy yellow, distinctly edgec with bright crimson. This is indeed a princess.

Princess Bonnio.-(New,) Rich velvety-red, free bloomer.

President Carnot.-(New.) Lovely fawn, shading to pearl. The best of all Roses.

Pink Soupert.-A lovely pink bedding or pot Rose.

Princess Alice de Monica - Creamy-white on the outside petals with a fant rosy-blush on edges.

Princess Venosa. - A lovely combination of deep rose and yellow shades. Very beautiful.

Queen's Scarlet. - A grand bedding Rose of richest scarlet.

Rod Malmaison. - The color is a rich, dark crimson.

Rainbow.-Blotched and streaked pink and crimson.

Souvenir de Victor Hug0.-Color a lovely citron-red, with amber and fawn shading.

Sunset.-This is an exquisite orange-yellow variety, Best Tea Rose grown.

Striped La France.-Same as La France, except the color is pink, with light stripes through it. Superb.

Snowflake,-Pure white. Most profuse bloomer of all Roses.

Souvenir of Wootton.-Rich crimson Roses in large clusters.

Striped Mlalmaison.- Just what its name indicates.

Souvenir de Catherine Guillot.-(New.) Color coppery-rose, center shaded orange. Very beautiful.

Souvenir de Madame Eugene Verdier.-Creamy-white, shading to yellow. This is a very desirable new Rose.

Sylph.-(New.) Flowers ivory-white, tinted with peach color. A very beautiful blending of colors.

Triumph de Pernet Pere.-Magenta-red, passing to rich crimson. A very fine variety.

The Queen.-Beautitul long buds. The color is a pure snowywhite.

The Bride.-This is a pure white Rose, of the largest size, buds and flowers of most perfect form

Viscountess Folkestone.-Pure white, faintly tinted fawn.

White Perle des Jardins.- The color is pure white.

White La France, - The color is pure white, faintiy tinted fawn.

White Bon Silene.-Same as Bon Silene, except the color is pure snow-white.

White Maman Cochet.-(New.) Pure white. The best garden Rose.

White Bougere.-A grand Rose for the garden. Identical with Bougere, except the color of flower is white. 


\section{EVER-BLOOMING ROSES}

\section{FOR GARDEN PLANTING.}

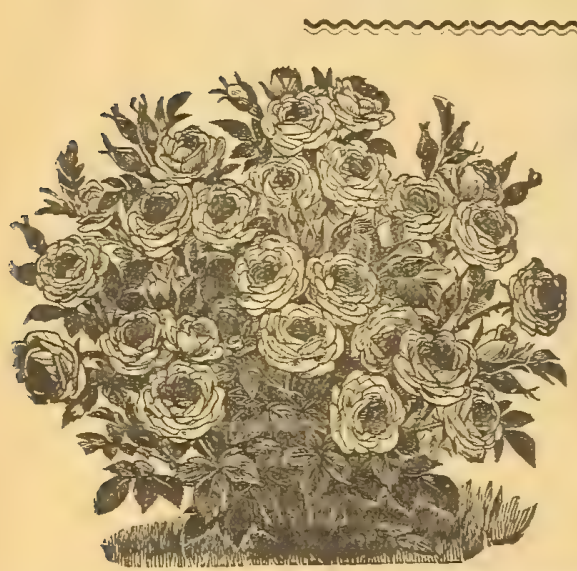

余

㷊

Your selection of twelve sorts from the list below for גi.

㷊

禁MY ROSES ARE ALL

ON

ATD I GII

OWVN

Greotren

ROOTS,

TRUTE TO NAME.

This List contains the old Standard Sorts, many of which will never be equaled by new and expensive sorts,

Large two yearrold plants from this list at 20 cents each, or six for $\$ 1.00$.
Aurora.-A grand pink garden Rose.

Adam.-Bright flesh salmon-rose, extra large and double. Alba Rosea.-Beautiful rose-colored center, shaded blush, Aline Sisley. - Violet-rose, a fruity, pleasant fragrance. Andre Schwartz.-Beautiful crimson, free flowering variety. Anna Ollivier, - Lovely blush, shaded with carmine. Antoine Verdier. - A rich, dark carmine-pink; very free. Apolline.-Clear pink, dashed rosy-carmine.

Arch Duke Charles.-Brilliant crimson-scarlet, shaded violet. Bella,-Pure snow-white, long, pointed buds, Tea-scented. Bon Silene.-Deep salmon-rose, illumed with carmine. Bongere.-Bronzed pink, tinged with lilac. Large and full, Canary, - Light canary-yellow, beautiful buds and flowers. Charles Bovolli.-A lovely shade of brilliant carmine. Theshunt Hybrid.- Red, shaded with violet. Large and full. Comtesse Riza du Parc--Coppery-rose, tinged soft violet. Crimson Bedder.-Bright fiery-red, velvety. Recommended. Devoniensis,-Creamy-white, Magnolia fragrance.

Douglas.-Dark cherry-red, rich and velvety, large and full Duchess de Thuringe.-Beautiful silver-rose, finely cupped. Enfant de Lyon. - An elegant mingling of pink and yellow. Edouard Litteya.-Pink and carmine, changing to pale rose Edouard 1 .

Eli Besaharnais.-Bright red; hardy. A valuable Rose.

Empress Eugenie.-Lovely pisk color. Much admired in the South.

General Tartas.-Deep mottled rose, sometimes tinged buff Homer. - Soft, ciear rose, with a salmon shade; splendid. Jules Finger.-Bright rosy-scarlet and intense crimson. Joseph Hetral.-Carnation red, passing to carmine. Extra. Ls Phoenix.-Deep pink, changing to light pink; free bloomer. La Princess Vera,-Pale flesh, changing to salmon.

La S slohide.-Blush, with fawn center, very large and double. Louis Philippe. $-A$ rich, dark velvety-crimson; free and beautiful Lucullus,-Beautiful dark crimson-maroon, full and fragrant. Madame Isaac Periere.-Deep pink; hardy. Good grower.

Lanrice Bouvier.-Pink, shaded buft and crimson, bordered white.
Madame Martha du Bourg.-Creamy-wihite, edged deep rose.

Beautiful.
Marquis de Vivieus.-Deep red, shaded salmon, yellow and fawa. Miss Edith Gifford.-Lovely white, flushed with rose. Beautiful, Iadame Bravy. - Creamy-white, large, full, very symmetrical. Madame Caroline Kuster.-Bright lemon-yellow, very large. IIadame Damaizin. - Salmon-rose color, changing to amaranth. Madame de St. Joseph.-Carmine, changing to salmon or fawn. Madame de Vatrey.-Red, shaded with salmon. Good form, Madame Jean Sisley.-A pure white. An elegant Rose. Madame Joseph Schwartz. - White, flushed pink, cupped. Madame Jure.-Lilac-rose, good size and substance, fragrant. Madame Lambard.-Rosy-bronze, changing to crimson. Extra. Madame Lambard. - Rosy-bronze, changing to crimson. Extr.
Madame Lawrence.-Button Rose. T wo colors, pink and red. Modame Margottin.-A cition-yellow, with coppery center. Madame Panline Labonte - Salmon-rose, large, full and sweet Marechal Robert. - Pure white, tinged and shaded rosy-blush. Marie Duchere. - Rich, transparent salmon, with fawn center. Marie Van Hontte.-A lovely pale yellow, suffused with pink. Monsieur Furtado.-Yellow, well formed, very fall and fragrant. Ifonthly Cabbage. - Rosy-red, globuiar shape and fragrant. Pink Daily.-Light pink flowers, produced in clusters. Pink Daily.-Light pink flowers, produced in clust

Parple Ching. Rich purplish-crimson, velvety.
Princess Hohenzollern.-Deep, rich red. Very handsome bud Princess Hohenzollern.-Deep, rich red. Very handsome Safrano. - A bright apricot-pellow, changing to orange and fawn. Sanguinea,-A rich, dark, velvety-crimson. Single.

Sombreail. - Beautiful white, tinged with delicate rose.

Souvenir de David.-An excellent dark crimson variety.

Souvenir d'nn Ami. - Fine, delicate rose, shaded with salmon.

Triomphe de Lazembonrz.-Rosy-carmine on a buff ground.

Virginia.-Light yellow, tinted with saffron

Virginia.-Light yellow, tinted with saffron,
Viscountess Wautier.-Belongs to the Brabant family. Light scountess Wautier. - Bel
rose, amber shadings.

Viridifiora.-The flowers of this variety are pure green.

Valle de Chamounix. - Glowing copper and rose. Lovely. White Daily. - Pure white, beautiful long, pointed buds.

\section{WINTER-BLOOMING IVY GERANIUMS.}

One of our local florists who grows for the home market a house full of these new Ivv Geraniums says that he sells as many of them as all other Geraniums combined. This speaks volumes for their loveliness. Try them.

New Double Ivy Geranium, Comtesse Horace de Choisenl.-A fit companion of "Joan of Arc." The plant is vigorous, leaves without zones, flowers very large, two inches across, double and imbricated, in good trusses. Color a bright, golden-sal. mon. We have no hesitancy in saying that this is the richest colored flower of any grown. All who see it say, "Is it pos. colored flower of any grown, All pho see it say, "Is it
sible that is a Geranium flower?" Price, 15 cents each.

Now Double White Iry Geranium, Joan of Arc,-"This is one of the most beautiful plants that it has ever been our privilege to offer. The flowers are perfectly double, white as snow, and literally cover the plant when in full bloom. The foliage is extremely handsome the dense glossy- The foliage is extremely hafecive, the cense, glossy-green leaves snow-white flowers." The foregoing was our description of last year, and another season's trial makes us heartily endorse it. Price, 15 cents each.

Now Double Scarlet IVy Geranium, Peter Crozy,-A grand hybrid between the Zonals and Ivies, having the foliage of the former, but very heavy in texture, and while the forms of truss and florets are found only among the Ivies, the color is a soft, bright scarlet, with veinings of maroon. A most distinct and pleasing variety, being the nearest approach to a scarlet yet introduced. Habit of plant very dwart and com. pact, and one of the most prolific flowering sorts in existence. pact, and one of the
Price, 15 cents each.

New Double Ivy Geranium, Souvenir Charles Turner.-One of the handsomest Ivy Geraniums ever introduced. Florets two and a half inches, in trusses sir inches across. The color is a deep bright pink, approaching scarlet in color, the upper a certificates. Price, 20 cents each.

Nen Double Iv Geranium, Galilee,-Another grand sort. One of the most remarkable of recent introduction. The trusse are of immense size, flowers very large and double, and of most charming shade of lovely rosy-pink, varied with lilac. A magnificent variety. Price, 15 cents each.

SPECIAL OFFER. - The Set of Five Iry Leaves for 40 cents. Any three for 25 cents. 


\section{GERANIUMS THAT ARE ESPECAMLIY SUTAABLE GERANIUMS FOR WNITER BLOOMING, $\ldots$ in}

\section{These Ten Best Double Geraniums for 75 Cents.}

Alivine Beguty - In this we have the finest double white Geranium ever introduced and unlike other double white Geraniums, it is suitable for pot culture, and flowers as profusely as the best single varieties. It is a dwarf, compact-growing variety, with handsome foliage of a light and healthy green. The perfect double flowers are unsurpassed for cut flowers. They are borne in large trusses and are spotless snowywhite, retaining their pure whitenes

Beruty Poitevive-Very la rge double flowers, in immense trusse

New Geraniom, Bruant.-S e mi double. The leafage is round and nicely zoned, having a greater texture and substance than even the most vigorous of the old type. Color of the flower a light vermilion-red of a most pleasing shade. The flowers are absolutely perfect in shape, contour and make-up, trusses exceptionally large, and borne in immense spherical balls, often measurin eight inches in diameter. It does finely in the open ground and is perfectly reliable as a bedding Geranium of the high. est merit. It makes a com pact mense It m pact, dense growth, and has make the perfect bedder that it is. Fine also in pots.

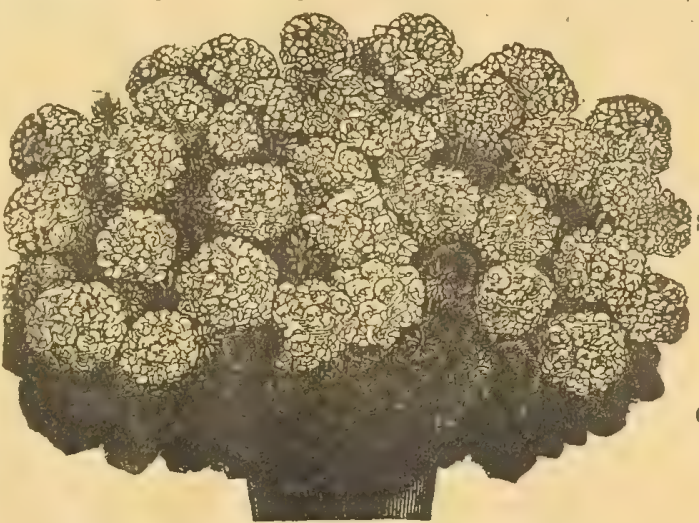

NEW DOUBLE WHTTE GERANYUM, ARPINE BEAUTY. very dark and rich, and at the same time very bright. Sim. ply superb.

O Brand.-Color dazzling flame scarlet, fine, prominent truss, flowers large and of great substance. An excellent bedder and pot plant.

loire de France.-Large, round florets of waxy appearance colors carmine and white, with carmine center, each peta delicately tinged with carmine. An excellent pot variety, to which its habit is finely sujted. It is one of the prettiest Gera. niums we have. This is the most beautiful of all particolored Geraniums which ap. pear so bewitching to the eye. The very brightest color im aginable.

Sir Walter Scott.-Color a beautiful vinous rose, with distinct white center. This variety produces fine individual florets, and combined with its other good gualities, makes it a valuable Geranium. This variety supersedes Sergeant Bobillett being a much finer Geranium. Gertrude.-Color of the flower a clear, bright salmon, with center and vuter edges touched with white, and with soft. shadings of carmine, velvety in texture.

Centanr. - The new mammoth Cen taur double Geranium is therous sized flowers, round, in the shape of rosettes. Color a bright orange-red, reverse of petals silvery. Very fine. Semi-double flowers.

Crimson Velvet.-This is the darkest and richest Geranium grown, It is very bright, dark, deep, rich velvety-maroon, best large-flowering double pink Geranium in cultivation. Any one seeing a specimen truss cannot fail to become enthusiastic over it, pronouncing it the largest and finest Geranium in cultivation. The new Centaur is remarkable fo its stout, robust growth, and for its immense trusses of bloors.

\section{These Ten Best Single Geraniums for 75 Cents.}

Iarguerite de Larres-A grand single white, plants a mass of white bloom, trusses of the grandest size, florets extra large white bloom, trusses of the grandest size, florets extra large and of the purest white. The plant is robust.
pots or bedding. It is by far the best single white.

Blanche Monlas.-A grand bedding variety of much merit. The fowers are large, salmon, beautifully bordered with white A Geranium of rare beanty.

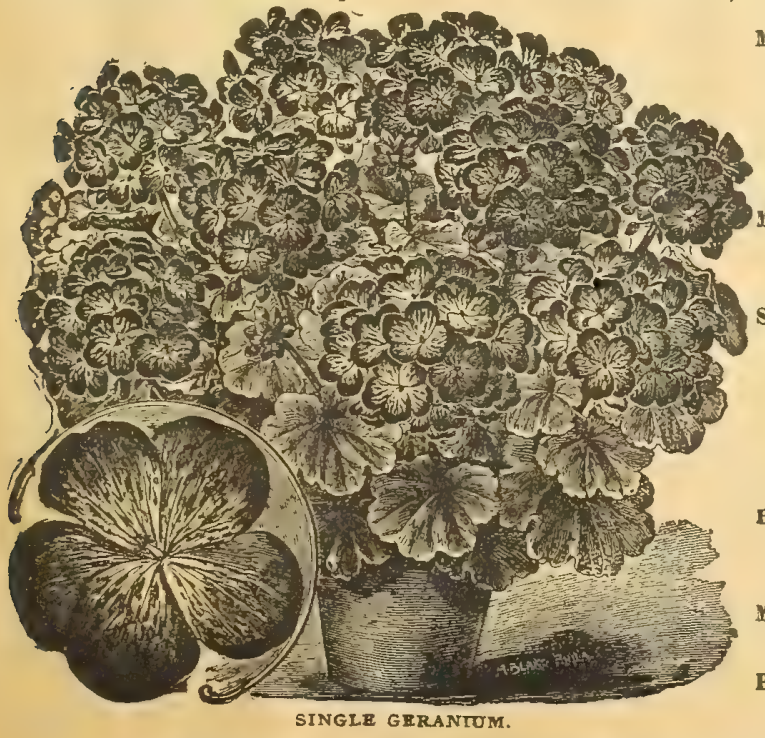

Lansdorn-A soft, deep scarlet, florets large and round, and formed into large trusses, borne with the greatest freedom. An ideal bedder, producing a mass of soft, brilliant color, well above the foliage, which is a light, bright green.

M. Noury - A most pleasing lavender-rose color, very chaste and beautiful, with distinct marking of white at center of flower. Dwarf, and so free in bloom as to literally cover the plant.

Madame Alfred Mame.-A magnificent bedding variety. The trusses are of extraordinary size, the florets by actual measurement being wide, of almost Pansy form. The color is a soft sub-scarlet. lower petals shading to salmon in the center, which is deeply veined crimson. This variety has been, universally admired by all who have seen it in flower. A variety that will prob. ably never be equaled.

Irs. E. G. Hill, - A most distinct and pleasing shade of salmon with light shading at the center. The shading at the cente is variable, however, Trusses are very large and composed of an immense number of florets.

Sonvenir de Mirande.-The greatest novelty in new Geraniums that has appeared for a number of years is undoubtedly Souvenir de Mirande. It is entirely distinct from any othe variety known, and is quite different from the usual marked. varietses that have from time to time made their appearance. It has round florets, upper petals creamy-white, with a distinct rosy-pink border, lower petals.salmon-rose, streaked. pure lilac It is extremely free-flowering, and produces fine trusses of its magnificent blooms.

Beanty of Bichmond.-Intense orangescarlet, very dazzling, with large white eye, flower perfectly circular and of im mense size, foliage lightly zoned. A.seedling from Beauty of Kent. Extremely free.

Ionsienr Poingignon. The color is bright aurora-rose, shaded salmon, with a white eye, Large trusses of splendid-shaped flowers.

Proteo.-Flowers are very large and freely produced in immense trusses. Color silvery-lilac, white shading; changing to silvery-pink. A splendid sort. 


\section{"WINTER" COLLECTION OF Síx Beautiful Carnations.}

There is no sweeter flower than the Carnation, and they are without question the best of all plants for Winter blooming. I have selected six of the very choicest kinds, including all colors of this delightful flower, and know you will not be disappointed in getting these varieties. They are large plants, ready to begin blooming at once. Many of them will be in bud when $\mathrm{I}$ send them to you.

"Winter" Collection of Carnatious, 10 cents each; or the Set of six for 50 cents.

Della Fox.-Its color is almost indiscribable. Of a rosy orange shape, striped and fiaked with carmine, never bursts its calyx, is very free and early flowering, and can always be cut with a long stem, a most desirable feature in a colored Carnation nowadays. It is very easily grown and sure to bloom.

Flora Hill.-I believe this to be the finest new or old Carnation in cultivation. The flowers are of the purest white, with petals of great substance, making it one of the best. It will keep a long time when cut. Fragrant and very productive of bloom, and, in all, one of the best for Winter blooming.

Abundance.-Flowers very large and perfect in form. Color a bright rosy-pink, with salmon shading when the flowers are tully expanded. Healthy grower and remarkably free bloomer. Plant dwarf, growing about fourteen
inches high. One of the best pink varieties. Excellent for pot culture.

Jubilee.-Very dwarf, and of a nice, bushy growth, forcing very long flower stems, each individual flower possessing a stem varying from three to elght inches in leagth. It has perfectly-formed flowers. Color a rich, bright. dazzling scarlet. Recommended.

Secretary Blaine.-A grand Carnation, with enormnus-sized flowers, often measuring three and a halt inches in diameter, and at the same time being one of the freest-blooming Carnations I have ever seen. Ground color of tions I have ever seen. Ground color of penciled with the richest crimson.

Anna Webb. -The color is of the darkest and most intense velvety crimson-maroon, very dark, and at the same time very bright.
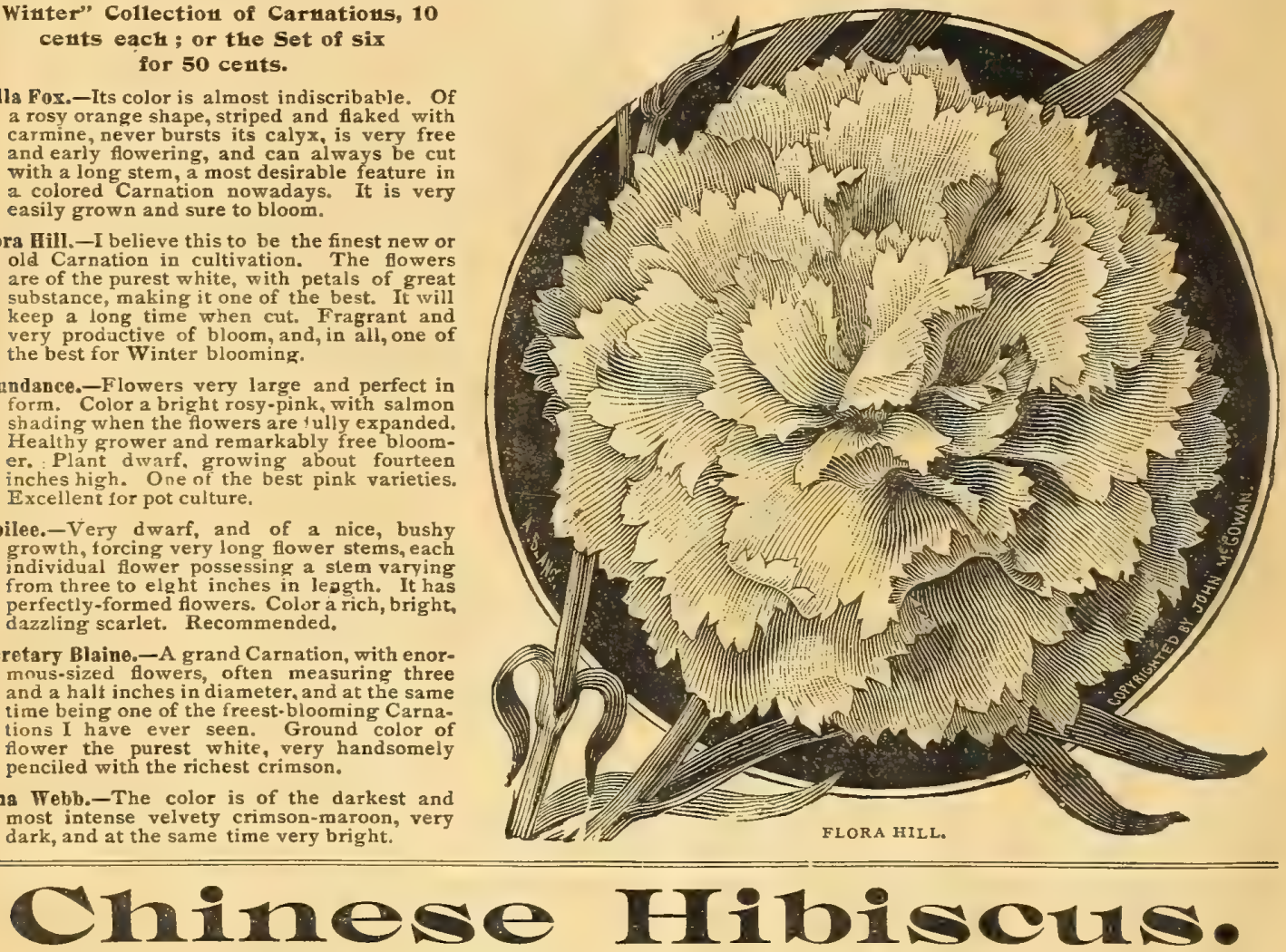

Price, 10 cents each : eight sorts, of our selection, for 50 cents. Large two-year-old plants, to bloom at once, 25 cents each.

Carminiatus Perfectus:-Full, round flower of perfect shape, and of a rich, soft carmine rose, with deep crimson eye.

Collerii.-Flowers buff-yellow, with a crimson-scarlet base. Peculiarly handsome.

Cooperii Tricolor. - This beautiful Hibiscus has the most invely foliage of deep green, crimson, pink and white, blended nicely; flowers deep crimson.

Double Crimson.-This grand variety has immense flowers of the richest crimson. Combined with glossy foliage renders it the best of all.

General Courtigis.-Very grand, large-sized flower, single, light scarlet; very showy. This is the brightest of all.

Grandiflorus.-Rich, glossy foliage, literally covering the plant with scarlet-crimson flowers,

Hibiscns Anriantica,-Large, double, orange-colored flowers,

Ministus, Semi-Plenas.-Semi-double flowers of a brilliant vermilion-scarlet, petals waved and recurved, and very handsome.

Magnifleus.-A very large flower, and of perfect form. Color a deep magenta, ends of petals touched with brown, foliage finely toothed.

Snb Violaceous, - Flowers of enormous size, of a beautiful car mine, tinted with violet, probably the largest flower of the Hibiscus family, and an unusually free bloomer. I take great pleasure in recommending this fine plant.

Schizopetalns. - A curiousiy formed flower pendant, the petals in whorl, orange-red, totally unkike any other Hibiscus, or in deed any other flower, the petals are open like Iace-work Not only a great curiosity, but highiy ornamental.

Senator Evans.-A beautiful Hibiscus. The shape of its flower is idenucal with the Auriantica, and has the same purple markings at base of petals. The color of this variety, instead of being orange, is a bright lemon color.

Sinensis Giganteus. - This is a plant for house culture during Winter or Summer, or for plunging outside during Summer. It blooms at all times during the year. The plants make a hard wooded shrub tike an Oieander, branching freely and fow fowering profusely, commencing to bionm when not more it has an equal only in the Brugmansia. Its flowers are of it has an equal only in the Brugmansia. Its flowers are of and of such a vivid crimson-scarlet color that they can be seen for a long distance like a flaming torch. It is hard to find anything among flowers more strikingly showy. They can be wintered in a cellar or pit with perfect safety, and if one does not care to grow th. $m$ all Winter, one should have one or two for Summer display. No plant is surer to grow and thrive umder any treatment than

Fersirolor.-A variety combining in its finwers all colors of the whole tamily, being handsomely striped crimson, buff, rose, and white.

Zebrinus - Double, the outer petals scarlet, edged with yellow, inner petals are very 1 rregular, curiously variegated with creamy-yellow-white.

SPECIAL OFFER. - The Set of Hibiscus, fifteen varieties, splendid plants, for \$1.00. 


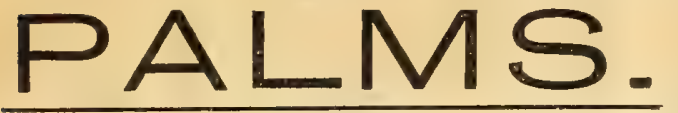

The following is a select list of rare and handsome varieties that can be recommended for apartments, conservatories, decorations or vase plants during

Summer. They are all grand plants, and of the easiest culture.

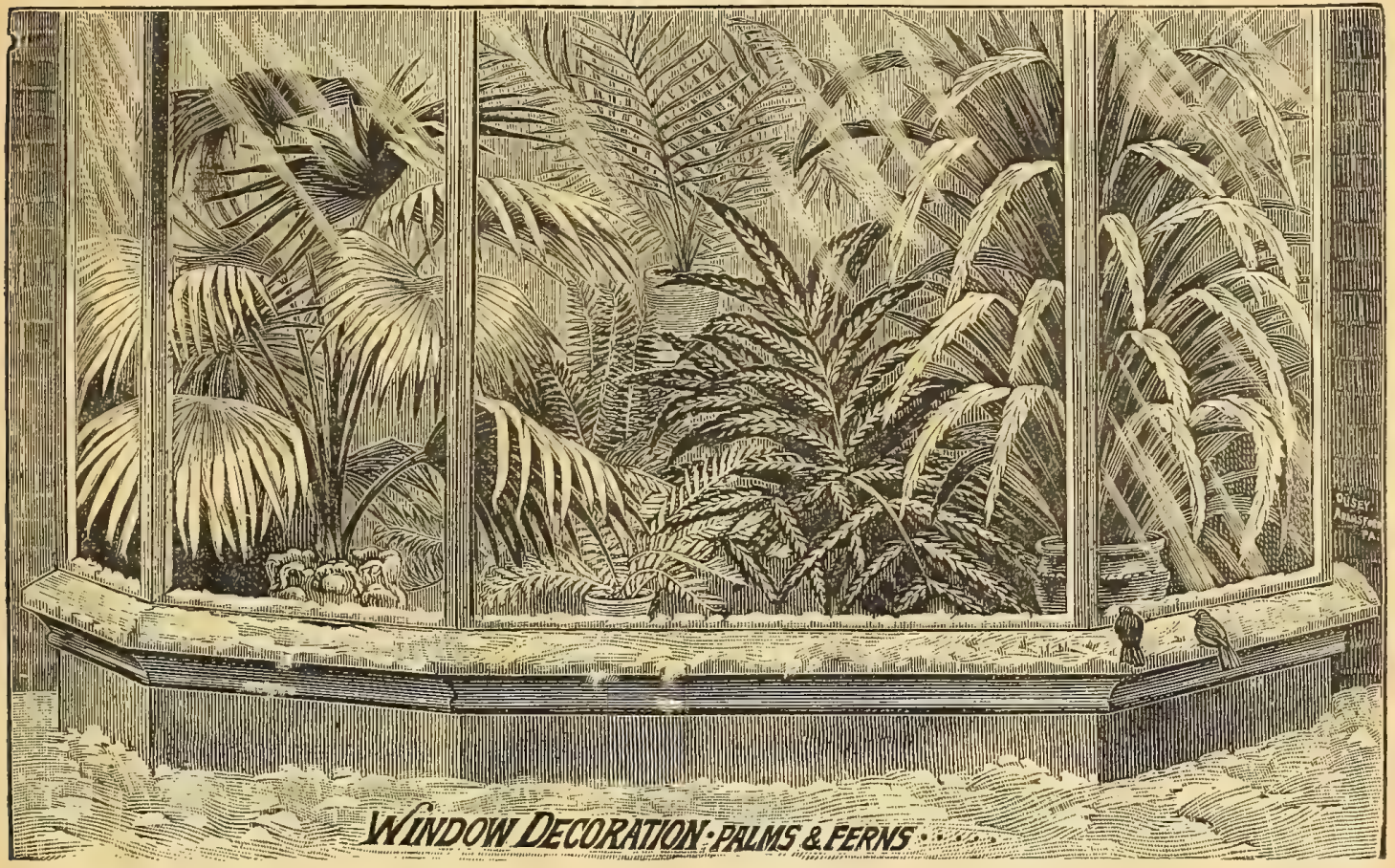

NOTICE.-It may be well to state here that young Palms do not resemble the illustrations given, as they do not show their character leaves until the second year, so that when you get your small Palm plants and see long, narrow leaves instead of the character leaves as shown in the illustration, do not think the wrong kind has been sent you.

\section{WASHINGTONIA FILIFERA.}

A beautiful $\mathrm{Palm}$ is one of the finest additions that can be made to any collection of plants, but the high prices of the best varieties have prevented most people from possessing one. Then again, there are but few of the best sorts which succeed well with ordinary window culture, It is, therefore, with pleasure that $\mathrm{am}$ now wile to offer one of the most beautiful sorts in existence, and one that is hardy and robust enough to succeed anyistence, and one that is hardy and robust enough to succeed anywhere, at a price which brings it within the reach of all. It has elegant dark-green, fan-shaped leaves, from which hang thread. like filaments. The plant is a compact grower, well adapted to that will keep a Geranium alive. It will flourish in any window for anybody, making a grand ornament during Winter, and in Summer it can adorn a veranda, or be placed about the graden or yard, or used for a center in a vase, basket or flower bed al ways ornamental anywhere. All Palms of the fan-leaved sorts have, when young, leaves of a long, narrow shape, developing the round, fan-shaped ones as they grow older. Therefore, when the round, fan-shaped ones as they grow older. not think that a wrong sort has been sent you. Price, so cents each; three for 25 cents.

\section{LATANIA BORBONICA.}

The well-known Fan Palm. This is one of the most exquisitely graceful among Palms Its wide-spreading, gracefully arching leaves are elegant and effective for apartment decoration. It is considered the handsomest and most valuable of all the Palms. Price, 25 cents each; fine plants, $\$ 1,00$ to $\$ 2,00$ each.

\section{KENTIA FOSTERIANA.}

This is one of the finest pot plants imaginable, and the easiest to grow of any of the Palm family. Being almost hardy, it is not injured by slight changes in te mperature, and its stiff, glossy leaves enable it to stand the dry, hot air of the living room without injury. The leaves are a deep, glossy-green, fan-shaped, split deeply into segments. This is, without exception, the most hardy of its class. Very graceful for table decoration. Scarcely equaled. Price, 50 cents each; strong plants, \$1 00 to $\$ 2.00$ each.

\section{COCOS WEDDELIANA.}

Undoubtedly the most graceful Palm yet introduced to my collection. The stem is slender, leaves long and very gracefully arched, leaflets or pinnze very fine, deep green above, white below. Price, 60 cents each.

\section{PHCENIX RECLINATA.}

This favorite Palm is beautiful in all stages of growth. No plant is more easily grown, and none more tenacious of life, enduring the dust, the cold and heat from open windows and gas heated air of our dwellings. The demand for this particular kind is perhaps five times that of any other. Leaves large, pinnated, of a cheerful green color, plant of hardy constitution, adapted to all decorative purposes, within or without doors. Price, 25 cents each; fine plants, $\$ 1.00$ to $\$ 2.00$ each.

\section{SEAFORTHIA ELEGANS.}

A most graceful Palm eminently adapted for decorating greenhouse and garden. Makes a fine window plant. Leaves long, gracefully arched, dark-green, and the whole plant is perfectly smooth. Price, 25 cents each; fine plants, $\$ 1.00$ to $\$ 2.00$ each

\section{AURECA LUTESCENS.}

A most elegant Paim. One of the best for general decorative purposes, easily grown, useful in every stage of growth, fine purposes, easily grown, useful in every stage of growth, fine fine plants, $\$ 1.00$ to $\$ 2.00$ each.

\section{CyCAS REVOLUTA. Sago Palm.}

The Cycas makes a magnificent specimen plant, and is one of the most valuable plants grown for the decoration of the lawn or house. Their heavy, glossy, deep-green fronds resist alike the gas, dust and cold to which decorative plants are frequently exposed. Fine, shapely plants. Price, by express, first size, with twelve to fifteen leaves, $\$ 4.00$; second size, with ten to twelve leaves, $\$ 3.00$; third size, with seven to ten leaves, $\$ 200$ each.

\section{A GREAT BARGAIN.-FOUR CHOICE PALMS, OUR SELECTION, FOR 40 CENTS.}


Every Chrysanthemum on this page has won a gold medal. Indeed, some of them have won several. You can order them from this list with the assurance that any one of them will be beautiful. The price $I$ offer them at is very low, as you will see by comparing them with any flower catalogue published.

price, 6 cents each; any thirteen, your seleotion, for so cents.

dia Spaulding.-Too well known to need description. Pink and white of globe shape, largest size.

Abraham Lincoln.-Rich cream color, the petals are trumpetshape, and are arranged to form a perfect ball. A sensational variety.

Admiration.-A soft, pure creamy-white, each petal tipped with shell-pink, petals of irregular length, like satin ribbon.

A. Sranson.-An immense bloom of the brightest red, reverse chrome-yellow.

Beau Ideal.-A bright rose-pink, without touch of lavender shadings. The form is a somewhat flat, incurved shape, the outer petals horizontal, showing the bright pink, the incurving center showing a lighter shade.

Challenge. A perfect globe of deep golden yellow, of immense size. Has won gold medal and over fifty first prizes.

clinton Chalfant. - A magnificent golden-yellow, upright, Dahlia like petals, forming a finely-rounded flower. Magnificent.

Exquisite.-The petals are uprignt and show the bright pink shadings at their best. In color it is a deep, clear pink.

Edward Hatch.-Blooms of immense size, almost spherical, quite double. The color is a suft lemon, suffused with pink.

ara Hoyt.-An immense double Japanese bloom, of clearest and brightest yellow, a solid golden ball. A grand variety.

Zda Prass.-A snowy Japanese variety. Inner side of petals a rich wine-red, reverse a silvery-pink. On first opening the petals have a peculiar manner of twisting or curling, showing

air Maid of Perth.-A magnificent heavy bloom of largest size, borne on stiff, erect stems, upper petals incurve to center, while the under ones reflex closely to the stem, formin

Flora Hill.-Probably the finest white in existence. An immense double flower of great substance and depth.

Frank Thomp80n.-A fine pearly-pink variety, sl:ading to white. A fine grower, with stiff stems. Superb.

Golden Wedding, - A deep, bright golden-yellor of shining texture, very large in size. A good exhibition sor

Gorgeous. - Deep golden-yellow of the richest hue, of immense size. The petals are teathery, incurved and whorled. One of the finest, and no collection is complete without it. It is indeed gorgeous in its color and beariag.

Harry $\mathbf{E}$. Widener. - A very fine yellow. Those desiring fine pot fiowers should plant this variety extensively. It had no rival until Mrs. Craig Lippincott and E. Dailledouze came

upon the scene. It is still a prize-winner at all the shows. Helen Bloodgood.-A pure, clear pink, without a trace of purple
or magenta, globe form. A grand flower.

amber. When fully open the flower is almost spherical.

Interocean.-An ivory-white, very massive in build. This variety is in every prize.winning collection. None better.

Jessica,-For general purposes, as a cut flower and as a show variety, it is ahead of anything yet produced. Flowers average six inches in diameter, and when grown to a single stem, ten inches. Pure white.

King's Daughter.-Fine, pure snow-white, center petals irregularly drooping. Stout stem, very showy, loose, pure Japanese style. Flowers very large.

Kioto.-Very large, if curved yellow, strong, free grower, extra fine. Good for cut bloom. Does well as large specimens.

L. Canning.-One of the most highly prized among whites. It should be in every collection.

Lillan E. Bird.-A beauty in every respect. Of the very largest size, long, tubular petals, of perfect form, producing flowers which are twelve inches in diameter. The color is an exquisite shade of "shrimp pink," the flower when fully open beiag an immense half-globe. A magnificent variety.

Miss Gladys Spaulding.-One of the very best whites eve duced. A large, round, exceedingly well-built flower.

Marguerito Jeffords. - A fine flower of bright amber or chestnut color, a most rich and pleasing shade. One of the finest Chrysanthemums extant. Very lasting. Should be in every collection for exhibition.

Miss M. E. HcCowet. In this we have the loveliest of Chrysanthemums. The flowers are very numerous, always perfect in form and full to the center. Color the softest white, with a deep flush of pink through the outer half of the flower curv ing over the center, sometimes tipping the inner petals.

Marvel,-Mrs, President Harrison's special admiration at the Indianapolis show. Very large, fiat flower of regular rosette shape, the ground color is pure waxen-white, and on this is a large, irregular blotch of wine color. No two flowers similarly marked. The flowers will sometimes come a solid wine color. The contrast in color is very beautiful.

Ars. C. H. Wheeler.-Very large and perfectly formed flowers. It should be in every collection. A perfect incurve, outside of petals a bright orange, lined on concave side with brilliant red. One of the very Iargest.

Mrs, John Wanamaker $-A$ superb variety of perfect incurved form, resembling a flat ball of wood. Color pink and white nicely blesded.
Mande Dean.-An immense pink variety, finely incurved, petals broadly bell-shaped. One of the largest flowers exhibited at the Fall shows. Almost a pure self-pink.

Mrs. J. Lewis Childs. - The enormous flowers are as round as a ball, and produced in abundance on long stems. The pure snowy-white color develops a tinge of pink so exquisitely faint that one almost looks for the color in the light and not the flower. Used for decoration in the evening, this feature has been much admired.

Mrs. Winthrop Sargent.-Brilliant straw coler, incurved, carrying its flowers on long, stiff stems. Very large, if not the largest in this line of color. A large, grand flower.

Mrs. Langtry.-A perfectly formed, flat flower, of unusual size and perfection. Snowy-white in color, with broad brands or
ribbon petals. Altogether one of the very finest varieties.

Mrs. E. G. Hill.-The blooms are eight to ten inches in diameter; the color is a delicate lavender-pink. Petals incurved. The display of this variety at the World's Fair attracted all passers-by, and was admired greatly. It was the winner of twelve first prizes and gold medal.

Mrs. Clevelsud.-A pure white variety, with long tubular petals, flowers very large, like President Cleveland. It will be a general favorite.

Hikado-Exquisitely fringed flowers of crimson and gold, curved and plated, of irregular form. It is gorgeous beyond de-

Irs. A. Carnegie.-A bright, deep crimson, reverse of petals a shade lighter, broad, long and flat, of leathery texture, incurving on first opening, afterwards assuming the form of a large $\mathbf{P}$ xony; strong, erect, with heavy foot-stalks.

Mrs. Anthony Watterer.-This is an immense spreading flower. which has been produced eleven inches across, the individual petals being one and a quarter inches across, at first very pale blush on the outside, which tint it loses as it matures; when fully expanded it has the appearance of a bunch of white ribbon. Invaluable for cutting.

Mario Lonise.-Beautiful, incurved, white, with interlacing petals, outer ones reflexed closely around the stem, inner ones build ing up full to the center, forming a plumy globe.

Mrs.J.G. Whildin.-A handsome yellow variety, of pure tint, splendid in size and form, and a magnificent addition to the scarce, very early, large flowering varieties; has attained great popularity.

Mrs. L. C. Maderia.-A perfect, compact globe of bright orange color, petals upright, like unopened, pointed quills, constitution strong, stems stiff, flowers large and of the heaviest substance.

Mrs. A. J. Drexel.-A very early, large flowering variety, half spherical in form, petals long and arranged like rays, the color is a fine example of crimson-lake, quite double and a fine grower.

Irs. Jerome Jones.-Large, cream-white, incurved Japanese, sometimes showing a tinge of pink, high, round flower. One of the best Chrysanthemum flowers up to date. Indispensable for exhibition, grand stem and foliage.

Mrs. W. K. Vanderbilt.-One of the finest in the entire Chrys. anthemum family: a granaj, large flower of the purest white. anthemum family; a grand, large fower

Hermaid.-Very delicate pink, perfectly incurving, broad petals, extremely delicate in color and finish; extra good.

Pitcher \& Manda. - Who ever heard of Chrysanthemums having two distinct colors in one flower? But that is just what Pitcher \& Manda is. The outer five or six rows of petals are pure white, and of Dahlia-like form, while the center is a
bright, deep yellow, the two colors being sharply defined. Won gold metal.

Presldent William B. Smith. -An immense cupped flower. Outside petals salmon-red, center a deep Indian red. Enormous, free and distinct. Invaluable as a show bloom. A most excellent variety.

Bobert McInnes.-The color is bright scarlet and gold, while it is full to the last degree, a perfect globe in form. It is quite early, being in full perfection the last week in October, and can be had earlier. Very brilliant in appearance, as well as grand in size and form. One of the very grandest of last year's introductions. A sensational variety. Fine at all the shows.

Sugar Loaf. - Everybody's Chrysanthemum, being a fine grower, and perfecting numerous extra large flowers of bright yellow

or bronze-yellow, inner petals incurving, outer petals reflezed,
The 0 ueen.-A grand double white, of fine size and great substance, very rounded in form, incurving and full. Probably the most valuable novelty of 1895 . By far the best of its style, and a prize-winner wherever shown. This year has given us two of our grandest whites, Queen and Niveus, anc nearly equal in merit and totally distinct.

W. H. Lincoln.-A rich, golden-yellow, of finest form and shape. Splendid for cut-fiowers, and a magnificent bush plant. A No, I for all purposes.

Wenonah.-(Blushing Bride.) The base of the petals is pure white, laced with deep lavender-pink. This is a variety that is much admired, and we have grown a great quantity of them for this year's sales. Very beautiful. 


\section{"EXCELLETT" COLLETION}

OF

Ten Prize-Winning

\section{CHRYSANTHEMUMS}

\section{FOR ONLY 50 CENTS.}

This flower is well termed the Queen of Autumn, and is too well known to need a lengthy introduction.

Metual Friend.-Pure white, with touches of

Aolden Wedding. - The best large exhibition Mellow variety.

Mande Dean,-Grand rosy-pink. One of the best.

Merry Monarch.-Lemon-white. The size is startling.

Aettysburg.-A rich, deep crimson. Very bright and beautiful Lady Playfair.-This is the grandest of all

Irs. Hicks Arnold.-Old gold or bronze color. Magnificent large flower.

Mrs. Henry Robinson. - The grandest of all white varieties.

Mrs. Anthony Watterer. - Resembles a bunch of pink ribbon.

Solsr Queen.-Color golden-yellow, shading to lighter. Takes front rank in all exhibitions.

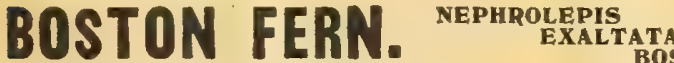
BOSTONIENSIS.

This grand new Fern has become the most popular decorative plant of the year. In and around Boston no other plant is so extensively used for table or window decoration as this graceful Fern. It is one of the very few plants that will thrive under ordinary house care. It grows and improves in size where most all other Ferns go back. The fronds droop and arch gracefully over the edge of a pot or basket, and as it is a very rapid grower it is not long before they reach the floor from an ordinary before they rin table. The color is a rich green, which contrasts beaufifully with all other window or pots. It thrives well in a dry, and frequent showerngs of the foliage by means dry, and frequent showerngs of the loliage by means of a plant syringe or a watering can are essential. To give an idea of the magnificent proportions of this Fern it may be stated that a single specimen plant, exhibited at the recent American Institute Fair in Madison Square Garden, New feet in diameter, some of the fronds being over fou ength. Price, large plants with fronds one and a half feet long, 15 cents each; two for 25 cents.
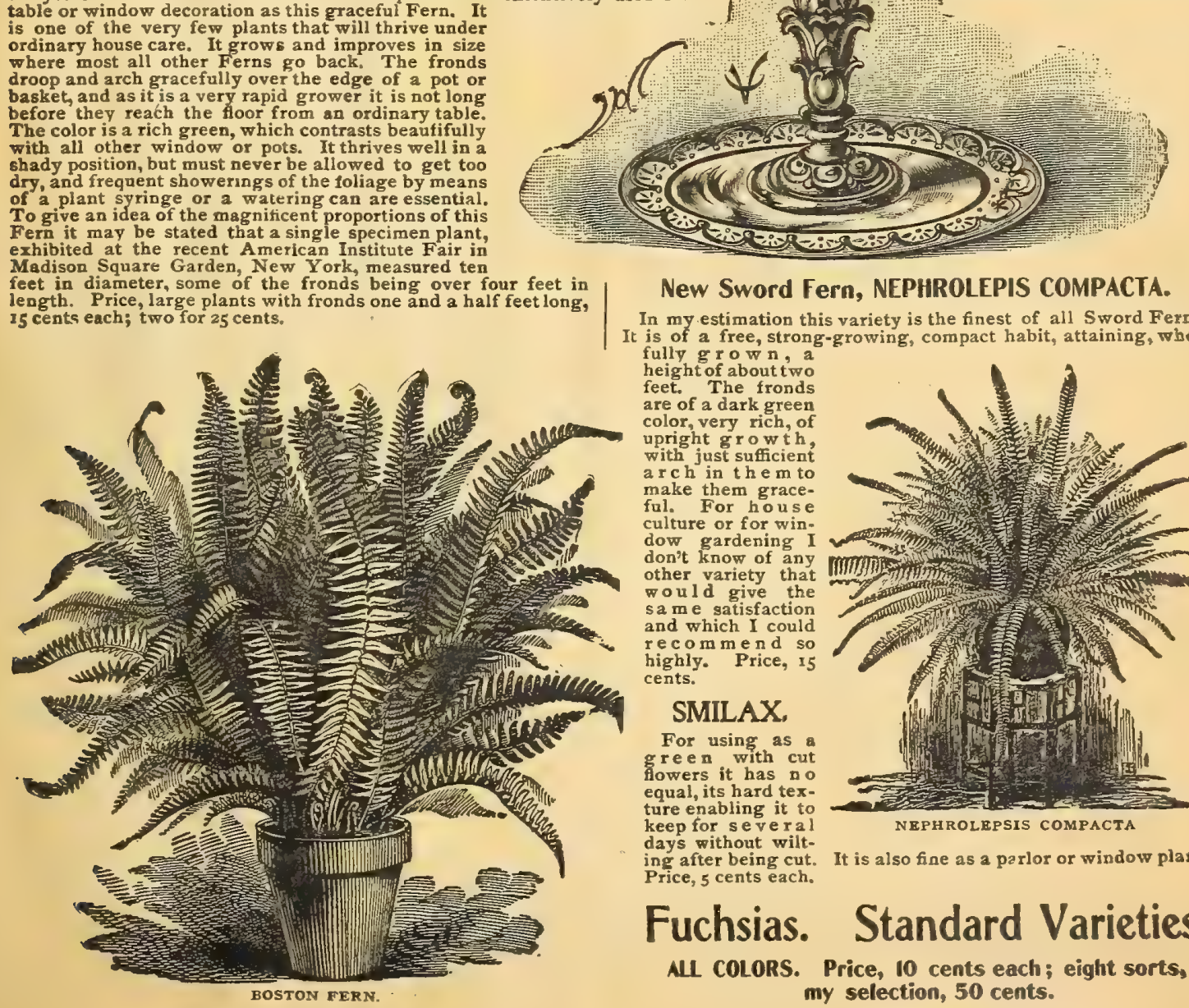

New Sword Fern, NEPHROLEPIS COMPACTA.

In my estimation this variety is the finest of all Sword Ferns. It is of a free, strong-growing, compact habit, attaining, viber fully $\mathrm{g}$ rown, a height of about two feet. The fronds are of a dark green color, very rich, of
upright g r o w th, with just sufficient a $r \mathrm{ch}$ in $\mathrm{th} \mathrm{e}$ to make them graceful. For house culture or for win: don't know of any other variety that would give the same gatisfaction and which I could recommend so

SMILAX,

For using as green with cut flowers it has no equal, its hard texture enabling it to days without wilt. ing after being cut. Price, 5 cents each.

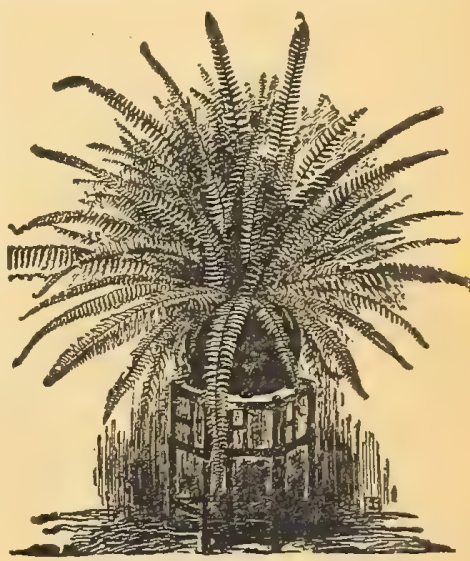

NEPHROLRPSIS COMPACTA It is also fine as a parlor or window plant.

\section{Fuchsias. Standard Varieties.}

All COLORS. Price, 10 cents each; eight sorts, my selection, 50 cents. 


\section{REX BEGONIAS,}

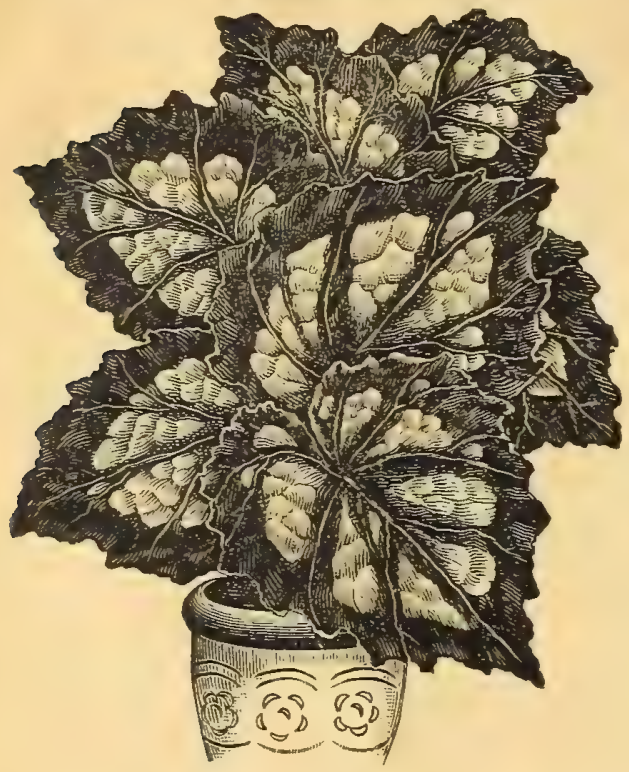

REX BEGONIA.

I have a fine "named Bet" of Rex Begonias, but limited space will not admit of my giving them here. Price, 15 cents each. I will select four of my choicest sorts in fine plants for only cents; two for 25 cents; ten distinct varieties for $\$ 1.00$. Order a set of these fancy Begonias and see how handsome they are. Must be seen to be admired.

So many of my customers write me: "Begonias are my favorite flowers, but I have no luck with them," gonili are my five principal points and if followed you can succeed with Begonias as easily as with Geraniums. I. Begonias delight iu perfect shade. 2, Begonias are great feeders; hence they like good, rich, loamy soil. 3. Begonias love moisture. Do not let them thirst one day and drown the next. 4. Begonias must be kept free from dust. Cover when sweeping. 5 Begonias must have drainage. Charcoal in small lumps in bottom of pot wil serve this purpose and keep the soil from souring.

\section{Winter-Flowering Begonias.}

Nitids Albs, - Similar in every respect to Nitida Rosea, but with white flowers, so profuse as to literally cover the plant with large clusters of a very waxy spray of flowers. Price, Is cents each.

Nitida Rosea.-A strong growing, profuse blooming variety, pro. ducing immense panicles of rose-colored flowers. Price, io cents each.

President Carnot,-A remarkably strong-growing variety, of stiff, upright habit, foliage large and something in style of Rubra, but more than twice as large, upper side deep green under side purplish-red, flowers beautiful coral red in large pendent panicles. Grand fowering variety. Price, 15 cents peach.

Sandersonii.-Coral Begonia. One of the best lowering Begonias. The flowers are of a scarlet shade of crimson, borne in profusion for months at a time. Leaves slightly edged with scarlet. Price, Io cents each.

Septrum.-A strong, upright growing species, with palmate leaves, which are ornamented with large silver spots arded with small sparkles, making a handsome specimen. Price, 25 cents each.

Marguerite.-Leaves a bronzy-green, somewhat resembling Metallica, but growing in more bushy form and easif $\tau$ to handle when grown for market. Large trusses of light, $r$ to colored flowers freely produced. Price, ro cents each.

Rubra.-If you can have only one Begonia, let it be a Rubra, for it will prove a constant delight. It is so last growing that it will in a year or two reach the top of your window, sending up heavy, stiff canes an inch in diameter, and rising beside them will grow strong, slender branches, gracefully drooping under heavy waxen leaves and pendent panicles of coral colored flowers as large as a hand. Medium sized plants are frequently seen with more than twenty such panicles at a time. Among the individual flowers you will find three distinct forms growing side by side. Price, 15 cents each.

Argentea 6uttats.-Pink and bronze leaves, with silvery markings, large bunches of white flowers. Price, 10 cents each.
[Begonias-Continued.]

Alba Picta.-It is shrubby in habit and compact in form, having long, slender, lance-shaped leaves on short stems, thickly siudded with silver-white, the spots graduating in size from the center towards the margin. Price, ro cents each.

Albs Perfecta Grandiflora.-Here I have a Begonia that has never been appreciated like it should be, as it is really elegant, and I doubt if there is a white-flowered variety that equals it. The foliage resembles Rubra in shape, but is a lighter green, while the flower panicles are much handsomer. Pure white flowering Begonia. Try it. Price, lo cents each.

New Begonia, Dewdrop.-In the new Begonia Dewdrop we have the best flowering Begonia ever obtained. Its graceful flowers are produced in profusion all during the Summer and Winter. It is a dwarf, compact-growing variety, the foliage is a bright, glossy-green, with shell-shaped leaves and stems is a bright, glossy-green, with shell-shaped leaves and stems
of light crimson. The blooms are produced in clusters of from six to eight florets, which are satiny-white, with golden-yellow stamens. Price, io cents each,

Ianicata Aurea, - The most beautiful of all the Begonias. Large, handsome leaves, beautifully blotched and marbled with green, white, cream and deep yellow. Price, 25 cents each.

Gloire de Lucerne.-Light green, handsome foliage, flowers borne in long, graceful, pendent chains, and of a delicate red color, very profuse bloomer. Fine. Price, 15 zents each.

Thurstonil.-I like this the best of all the new Begonias. It is iery much like Metallica, but is a much better Begonia in every respect. The foliage is a glossy bronze-green, with the under side a deep wine color. Flowers an elegant pink, shaded white. Price, I5 cents tach.

M. de Lesseps. - A very fine new Begonia, with fine tropical foliage and elegant flowers. Price, I5 cents each.

IcBethii.-Always in bloom, beautiful cut-leaf foliage, with snow-white flowers. Price, lo cents each.

\section{SWAINSONIA ALBA.}

This is a new plant, and one of which I cannot speak too highly. It is a rapid grower, growing into a compact, bushy form, and bears its panicles six inches long of pure white, peashaped flowers in the greatest profusion. It is very sweet and fragrant. I have been cultivating it for the past year, and it is seldom out of bloom either Winter or Summer. Be sure and try it, as it will be certain to please you. Price, ro cents each,

\section{NEW SWAINSONIA, SPLENDENS.}

Same as the above, with bright scarlet flowers. This is the only true scarlet variety. Price, 15 cents eaeh.

THE TWO SWAINSONIAS FOR 20 CENTS.

\section{CAMELLIA JAPONICA.}

The royal family of greenhouse plants. Leaves glossy-green and flowers of the most exquisite beauty and vaxy texture. From

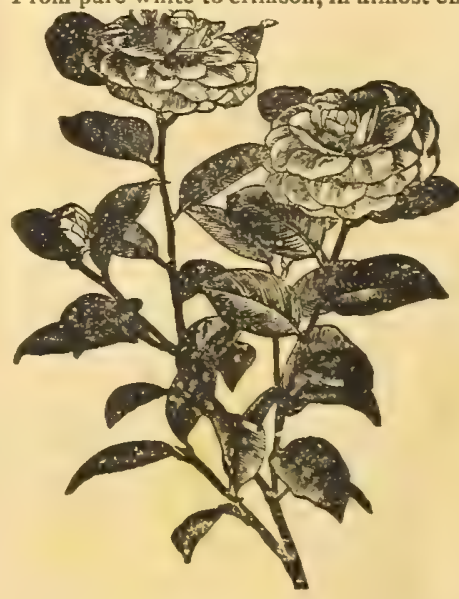

CAMELITA JAPONICA. pure white ones are generally prized above the colored va. rieties. Their culture is nearly related to that of the Azalea. but their success is but their success is more certain. Remoisture throughout the hot season. Their time of blooming is Winter and early Spring. Requires a moderate and uniform temperature with as little artificial lieat as possible. When set rvith fiower buds set with tower be taken in watering be taken in watering -when left too dry the buds are sure to drop. Price, for large, strong plants, 2 to $21 / 2$ feet in height, shapely, 75 cents each.

Sara Frost. -A brightcrimson. Fine.

Queen of Denmark.-Salmon-rose, fine form.

Lady Hume's Blush.-Flesh color. Extra fine

Jenny Lind.-White, with nink stripe.

Flmbriata.-Clear white, with the petals finely fimbriated.

Caleb Cope,-Clear blush rose. One of the best.

Americana.-Blush, mottled with rose.

Camellis, Albs Plena.-Double white, very fine, and the best white. 
AUSTRALIAN SILK OAK.

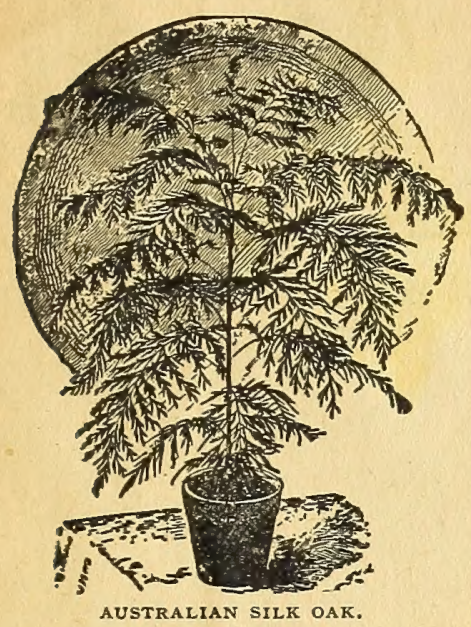

GREVILLEA ROBUSTA.

A splendid ferny leaved evergreen plant (not a true oak) which should be grown by everybody, as it makes a magnificent pot of decorative purposes. In conjunc. poses. In conjunc. Ferns, or in any orFerns, or in any or-
dinary collection of house plants, it is at once striking and graceful. The dust, heat and gas of living rooms has no visible effect on and it will thrive where a Geranium cents each; three for 25 cents.

NEW ASPARAGUS PLUMOSUS NANUS.

This graceful climbing plant has to a great extent taken the place of the once popular smilax in all fine decorations. It possesses the advantage of being much more graceful-its foliage being finer than that of the most delicate Fern, and will last for weeks after being cut, the whole plant being of a bright, cheerful
green. It is an excellent house plant, succeeding under almost green. It is an excellent house plant,

NEW ASPARAGUS SPRENGERI.

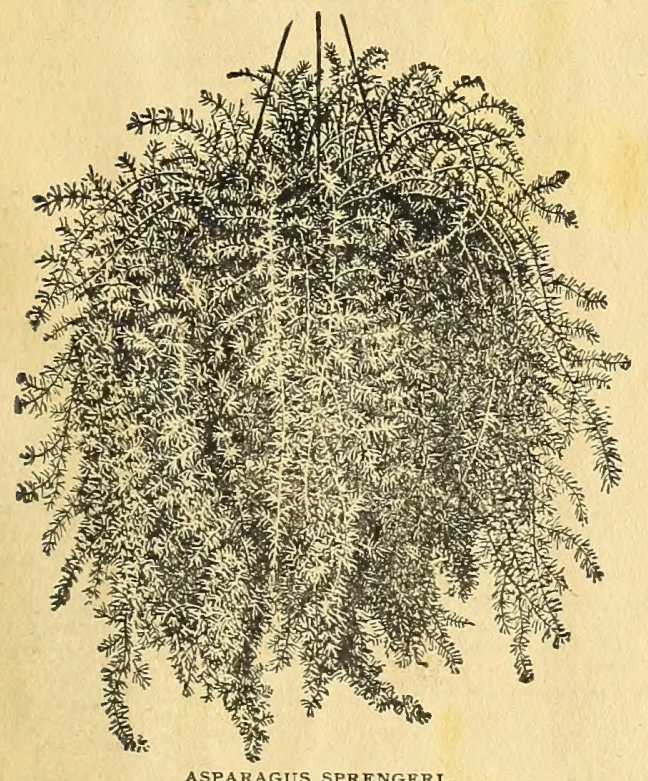

When introduced, at a high price, a little over a year ago, this plant was received with some little hesitation as to its desirability, but after only a limited trial it has come forward with prominence that the supply will be inadequate to the demand for some time to come. Not only is it useful for cutting in sprays for cut-flower work, but grown in suspended pots it makes one of the prettiest decorative house plants I know of. It is really handsomest seen drooping gracefully from a pot or basket. Sprays from four to five feet long, of a bright green feathery foliage, and as it will withstand dry atmosphere and grow well in shade or sunlight it is decidedly the most useful and suitable parlor plant. The flowers are white and very fragrant, followed by bright red berries. Mr. H. H. Battles, the well-known floral artist, says: "Grow all you possibly can of it; it's a grand thing." It is not only a plant that will be used extensively by florists for cut-flower work, but it is decidedly a extensively by forists for lor, table and window plant. It is hardier than any other Asparagus, can even be grown in open round any other Asparagus, can even be grown in open ground, and under good year-plants which have sold year-plants which have sold at $\$ 500$. I have so much faith in strongplants, 15 cents each; thousand plants of it now. Price,
ARAUCARIA EXCELsIA. Norfolk Island Pine.

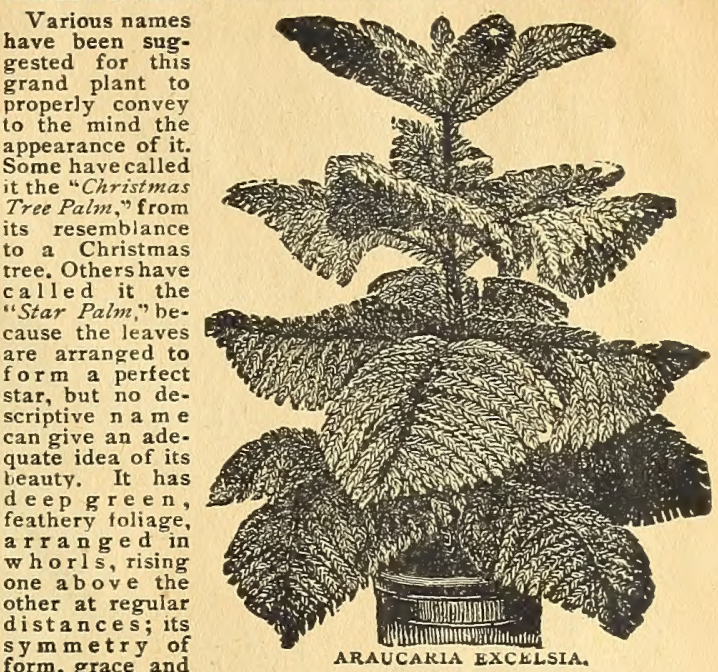

symmetry of

beauty of foliag $e$

are unequaled in the vegetable kingdom. It is easily grown in the house and is highly ornamental. It requires the same culture as the Palm. Indeed, as a decorative plant for the house this is one of the handsomest and most serviceable plants in my collection. Price, extra fine plants, fifteen to eighteen inches high, $\$ 2.00$ each; twelve to fifteen inches high, \$1.50.

FICUS ELASTICA, India Rubber Tree.

Very large, smooth, leathery leaves, evergreen foliage. Generally esteemed one of the finest house plants grown, the plant attaining a large size and tree shape. Each new leaf is enclosed in a long, coral-red envelop, looking like a great red flower bud. $A$ very fine plant for the lawn or bay window. Price, fine strong plants, $5^{\circ}$ cents each; Jarge plants, $\$ 1.00$ each.

\section{PRIMROSES.}

The following three fine sorts for 20 cents each.

Primrose, Obconica, the Ever-blooming Variety.-White, with lavender tints. Price, ro cents each.

Alba Magnifica,-The finest white, with greenish-yellow center. Price, ro cents each.

Kermissinus Splendens.-A deep rose, with a yellowish throat. Price, 10 cents each.

PANDANUS UTILIS. (Screw Pine.)

This is a charming plant, and is one of my most useful of ornamental plants. The foliage is green, edged with red; when the plant is fully developed, the leaves describe a perfect screw on the stem; hence the name, Screw Pine. This will go nicely with your Palms, and requires the same culture. Price, fine plants, 50 cents each.

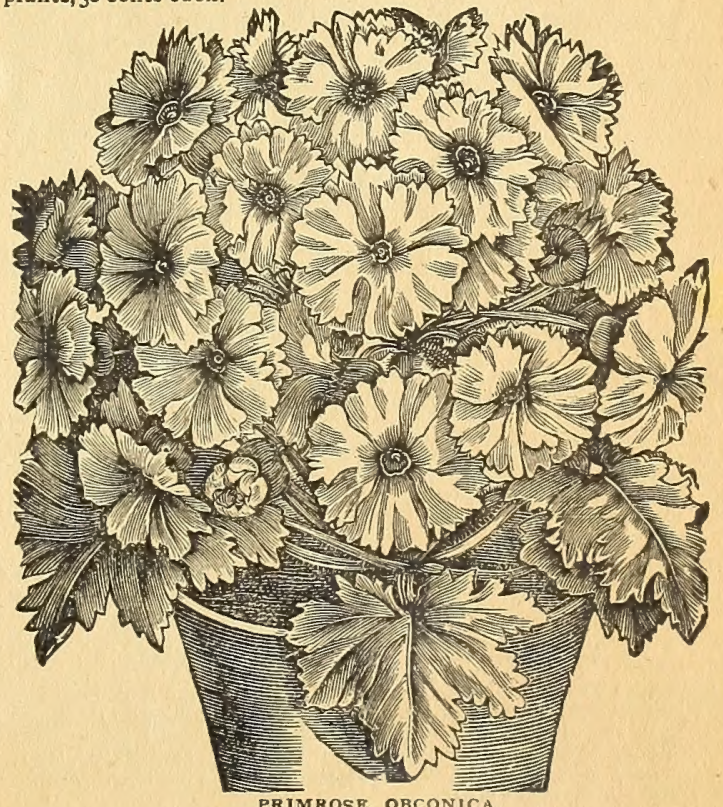




\section{Four Beautiful Violets.}

(1) F ALL delightful perfumes that of Violets is the most delicate and pleasant, and places the modest Violets grow and bloom during the dead of Winter with notrouble whatever, if given $2 \mathrm{cool}$ situation, but will not succeed in a warm place. The following, but will not soced in in color.

Lady Hume Campbell. - This is the finest of all double blue Violets. It is simply wonderful the number of beautiful flowers it produces. In color a lovely shade of the richest intense blue. A charming contrast with the white variety. Price, 8 cents each.

New Violet, California - This beautiful single-flowered Violet has created a decided sensation. It was raised in California, where it is cultivated by the hundreds of acres for cut flowers. Buyers prefer it to all others. It is entirely hardy and of the richest dark blue and very fragrant. Price, 8 cents each

New Double White, Perpetual Fowering violet, Swanley White, or Oneen of Fragrance--Of all the white Violets this is the best. either for pot either for pot house or bedded out. In pots it grows lux uriantly, and is flowers. It is not an uncom mon sight to fifty large flowers open at once, presenting $a$ beautifu sight, their delicious perfume filling a whole room. Price, 8 cents each.

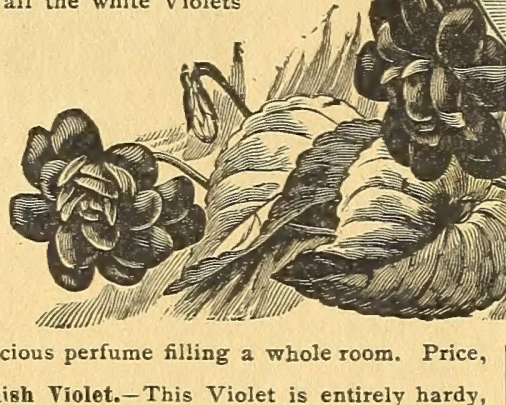

ardy Double English Violet.-This Violet is entirely hardy, perfectly double, a deep violet-purple color and most deliciously fragrant. It surpasses the well-known "Marie Louise" Violet in richness of color, being many shades darker, and far excels it in its delightful odor: this is one of its greatest merits. It is entirely free from disease of any kind, will grow and bloom in any garden and in any situation. Nothing is more appropriate for cemetery plots than the Hardy Double English Violet. Price, 15 cents each.

The Set of Four Lovely Violets for only 30 cents

\section{AZALEA INDICA.}

One of the most gorgeous blooming families, together with the showiest of all greenhouse plants. The colors of the flower vary from the purest white to the deepest crimson in untold variations. The soil should always be packed hard when transplanted. Success depends, however, on the degree of moisture in the atmosphere in which they live. We have a number of the best atmosphere in whill flower finely at nce, both double and fowering sorts that win color desired. The plants we offer are single-flowered, in any color desired. The plants we offer are days. An elegant present for Christmas. Price, three-year-old plants that have from forty to sixty blooms at blooming season, 75 cents each.

\section{OLEANDER.}

Double Yellow, Double White, and Double Pink.

Semi-double flowers, of pleasing and satisfactory shades. Price, the yellow variety, 20 cents each; the white variety, $1_{5}$ cents each; the pink variety, ro cents each.

\section{JUSTICIA, or Brazilian Plume Plant.}

Justicia Cornes.-Perhaps no plants have attracted so much attention in the last two years as the Justicia, or Brazilian Plume Plant. The plant is a strong, rapid grower, and throws up long stems, on which are produced fine plume-like pink fowers, the ends of each petal drooping in a most charming manner. When the plants are a few months old they are literally covered with their beautiful blossoms. It does equally well either for house or out-door culture. Price, Io cents each.

Jngticia Sanguinea.-Same as the above, except that it has ele gant red stems and flaming rose-colored blooms. Price, cents each.

\section{CYCLAMEN, or Persian Violet.}

Cyclamen, Persicum Giganteum,-This is a decided improvement over the old variety, being of a more robust habit and stronger grower. Produces flowers on short, stout stems, and of immense size, often measuring, on well-grown bulbs, two inches in diameter. The foliage is also beautiful. Price, good bulbs, 10 cents each.
Plumbago, Capensis.-The Plumbagos are always satisfactory plants, either for pot culture or for the garden. They are constant bloomers, and their delicate and graceful flowers are very useful for cutting. Capensis has plentiful clusters of the most beautiful pale blue flowers, a shade seldom met of the most beautiful pale blue flowers, a shade seld

Plumbago, Capensis Albs.-The exact counterpart of Plumbago Capensis, except in color, which, in this beautiful plant, is snow white. One of the most satisfactory of plants. Price, ro cents each.

\section{JASMINES.}

Grand Duke of Tuscany.-Easily grown, even small plants bearing a profusion of double, creamy-white flowers, having a delicious perfume. A plant of this lovely variety will, when in bloom, scent up a whole yard or house. It is by far the most delicious in bloom and fragrance of all Jasmines, or indeed, for that matter, I know of no flower that emits such a delightful fragrance. It is sweeter than a Tuberose, and that is saying a good deal for it. Will thrive out of doors and bloom through the season. A magnificent plant, and will become one of the most valuable and popular pot plants when it becomes better known. It can be stored in a dry cellar in Winter. It will please you. Try it. Price, fine plants, 25 cents each; large plants, 75 cents each.

Cape Jasmine.-The well-known variety grows into a fine, large bush, fine, rich, glossy foliage, and large double flowers of delicious fragrance. Price, 1o cents each; large plants, 25 cents each.

Now Jasmine, Maid of Orleans. - This makes handsome specimens in the South, where it is hardy. It will prodnce more flowers, twice over, than any of the Jasmines. Price, 15 cents each; large plants, 50 cents each.

Revolutum.-A yellow-flowered Jasmine, hardy and exquisitely fragrant. Price, Io cents each.

Maylayan, or Confederate Jasmine.-Now that climbers are so in vogue, I am pleased to be able to offer this very rare sort, knowing that it will delight every purchaser. To be able to have the most delicate, sweet-scented and pure yellow, waxylike flowers in profusion almost the whole year round, and dark, evergreen foliage to set them off to advantage, is something that cannot be had from other plants. For florists nothing could be more useful, as it blooms more profusely in Winter than at any other time, making it a most desirsble house plant. The vine will live a lifetime. Price, rocents each; large plants, 40 cents each.

Grandiflorum.-This is a beautiful plant, with small, glossy, evergreen foliage, handsomely arranged on long, graceful branches, which are inclined to vine. It blooms in the Fall and Winter, bearing in the greatest profusion small, pure white flowers of a spicy fragrance, which is fully delicious. A spendid house plant. Price, ro cents each; large plants, 25 cents each.

SPECIAL OFFER. - The six distinct kixds of Jasmines, costing 80 cents, for only 50 cents. A great bargait. 


\section{Cestrum Parqui, or Night-Blooming Jasmine.}

These beautiful shrubs are cultivated for the delicate frarrance of their elegant flowers, which are borne in clusters. It is of easy culture.

Costrum, Parqui.-This well-known and highly-prized plant, blooming nearly all the year, is a native of Chili. An excel lent garden plant, growing rapidly. Foliage long and of a deep green color. Produces its richly fragrant flowers at every joint. Sweet only at night. It is also well adapted to house and window culture. Price, ro cents each.

The Old-Time Favorite, Stephanotis Floribunda.

Always scarce. This is without doubt the rarest of all hardwood vines. It makes a rapid growth, and bears large clusters of deliciously fragrant white flowers. Nothing can compare with it for either the beauty of bloom or for its exquispare with it for either the beauty of bloom or for its exquisvery cheap. It is never offered at less than 75 cents or a dollar. My price, only zo cents.

\section{GENISTA CANARIENSIS. (Fountain of Gold.)}

This beautiful plant well deserves the great popularity it has gained in the past $t w o$ years. The drooping branches are covered with delicate, sage-green foliage, and every twig is tipped with a long raceme of exquisite, pea-shaped blossoms of a pure canary color, almost hiding the foliage, and suggesting the name, "Fountain of Gold." A fine companion for Swainsonia Alba. Price, 20 cents each.

\section{CHINESE MATRIMONY VINE.}

Plant it this Fall. It is ha ' - everywhere. A vine for permanent effect for shading c ny window, covering an arbor or veranda, and for perfect hardiness cannot be excelled. Pale purple flowers and scarlet berries are constantly appearing from purple fiowers and scarlet berries are constantly appearing from
early Spring till late in the Fall. Price, ro cents each, or three early Spring
for 25 cents.

\section{ABUTILON. CHINEE BELL FLOWER OR ABUTILON. FLOWERING MAPLE.}

The Abutilons we offer are perpetual bloomers, aud we wish all our friends to order a few Abutilons and see how fine they are. They are not the old tall-growing varieties that never bloom. Price, ro cents each.

\section{SPECIAL OFFER. The Seven
New Abutilons for 50 cents.}

Robert George.-A free and continuous bloomer. Flowers are broad, their large, over-lapping petals incurved, color orange, veined with crimson.

Shower of Gold.-A beautiful, dwarf-growing variety, the whole plant being covered with a profusion of beautiful goldenyellow blossoms.

Thompsonii Pleria.-New. Has perfectly double flowers that resemble in form a double Hollyhock. Color a rich, deep orange, shaded and streaked with crimson. The foliage is delightfully variegated.

Splendens.-A beautiful velvety-crimson.

Scarlet Gom.-A rich, bright scarlet.

Eclipse. - This is an elegant foliage plant, and one of the prettiest we know. It is new, and the flowers, which are produced in profusion, set the plant off to good advantage.

Now Abutilon, Souvenir de Bonne.-This is a charming plant. The body of the leaf is a deep, rich green, bordered and edged with purest white. It is a lovely plant to go with Palms or other decorative plants.

\section{HYDRANGEAS.}

SPECIAL OFFER.-The Six Hydrangeas, good plants, for 50 cents.

New Hydrangea, Stella Fimbriata.-This is the only double Hy drangea in existence. The individual flowers are perfectly double and resemble in shape small rosettes, a beautiful pink peach in color, very floriferous; flowers of the largest size. It is certainly a charming plant. Price, ro cents each.

太̃ow Hydrangea, Red-Branched,-(Ramis Pictus.) A valuable addition to the list of Hydrangeas, with dark red branches that brighten to a clear crimson color as they near the flowe trusses. The plant is of robust habit, and produces freely immense heads of deep rose-colored flowers. A novelty of sterling merit that is sure to become very popular. This is by all odds the prettiest Hydrangea. Price, 8 cents each.

Hydrangea, 0 taksa.- $A$ bright, rosy-pink, flowers always perfect, and lasting, when in bloom, three to four months. Try it. Price, 8 cents each.

Thomss Hogg.-A pure white variety, with trusses of flowers measuring fifteen inches in diameter. The plants, when ful grown, attain a height and width of six feet. Perfectly hardy. One of the finest plants for cemeteries. Price, 8 cents each.

Xor Hydrangea, Monstrosa. - This is by far the best of all Hydrangeas, the flower being almost double in size of the older varieties, and its free-blooming qualities are unequaled by any plant I know of. The color is at first a deep, rich pink, gradually changing to almost a snow-white. Blooms have been measured fifteen inches in length by ten inches through. It is indeed an enormous and beautiful flower. Price, 15 cents each.
(Hydrangeas-Continued.)

New Japanese Hydrangea, Paniculata Grandifiora.-A new, very striking and elegant hardy flowering shrub, suitable for lawns, recently introduced from Japan. The flowers are pure white, afterwards changing to pink, and are borne in immense pyramidal trusses more than a foot long and nearly as much in diameter. It blooms in mid-Summer, and remains in bloom two or three months. Creates a great sensation wherever seen. Is scarce and difficult to obtain. The plant is of a bushy and compact growth, attains a height of plant to four feet. Perfectly hardy. Price. young plants, Is cents each; extra strong, two-year-old plants, for immediate effect. 35 cents each.

\section{PEILOX - Hardy Perennial. (Plaut in the Fal1.)}

The new French varieties all carry very fine, distinct pure colors, in great trusses, many of them beautifully shaded and marked with very distinct, clear bright eyes. They require no ous growth and freedom of bloom make them very useful plants, ous growth and freedom of bloom make them very useful plants, this beautiful class of plants is perhaps more marked than in any other section of the hardy, herbaceous family. Instead of the thin flowers, which were limited to lilac and white colors, we now have gorgeous flowers combining all the different tints of salmon, with their distinct eyes. Perfectly hardy everywhere.

Price, 10 cents each; the entire set of seven for 50 cents. No in ther disconnt on this offer.

Phlox, Cross of Honor. - A beautiful light rose color, striped pure white. An excellent flower.

Lothair - A brilliant white and fre.

Princess de Furstenburg.-White, with carmine eye. Wh

Sir E. Landseer.-Brilliant, dark crimson. Large, fine flower. Stansted Rival.-Rose-pink, dark crimson rays. Triumph de Twickle.-A rosy magenta.

\section{SANSEVERIA ZEALANICA.}

A New Decorative Plant of Great Beauty and Value.

This is a very beautiful plant, splendidiy adapted for the decoration of drawing-rooms and halls, as it stands drouth and dust with impunity and requires scarcely any water. The leaves grow to a length of three to four feet, and are beautifully striped cross-wise with broad white variegations on a dark-green ground. The flowers are numerous and composed of long, nar-
row petals, which recurve gracefully, and are of a creamy-white color. Price, fire plants, ro cents each; large, strong plants, 20 cents each.

\section{OTAHEITE ORANGE, OF CHINESE DWARF.}

This is not a new plant, but one that deserves to be more generally known and cultivated than it is. It has the same deepgreen, fragrant foliage as the Sweet Orange, but is of decided dwarf, bushy growth. Plants only one year old, and not over ten to fifteen inches high, produce their delicious blossoms, which are succeeded by fruit. Nothing can be more ornamental and attractive in a collection of pot plants than one of these minute Orange trees, with half a dozen or more of their brightcolored fruits on, which get to be about one-third or one-half the size of the regular Oranges. Plants are of the easiest culture. Price, fine plants, ro cents each; large plants, 20 cents each. Fine, extra large plants, 30 cents.

\section{LEMON OF STCILY.}

Dwarf.-This is as much of a wonder as the dwarf Orange. It bears the largest Lemons of any variety in cultivation. A sin. gle fruit often weighs two or three pounds. A handsome companion for the dwarf Orange, as it boars fruit when quite small. The flowers are as fragrant as the Orange blossoms. Price, 15 cents each: large, strong plants, 40 cents each.

\section{CYPERUS ALTERNAFOLIUS-Umbrella Plant.}

This is a plant of the eastest culture, and a large specimen is as handsome as a Palm for decoration. It makes a handsome pot plant. It will grow luxuriantly in water, and is, therefore, indispensable for aquariums or fountains. Try it. Price, Io cents each; three for 25 cents.

\section{LEMON VERBENA-Aloysia Citriodora.}

Foliage delightfully fragrant. To simply brush against it is enough to scent an entire room with its delicions odor. Planted out of doors it grows into a fine, large clump, and it can be taken up in the Fall and wintered over in the cellar. Price, rocents each; three for 25 cents.

\section{ALYSSUM-Double White.}

The trusses are enormous, measuring at times one inch in diameter and five inches long. The flowers are perfectly double and of delightful fragrance. Price, ro cents each; three for 25 cents. 


\section{Sixty Choice Bulbs Free!}

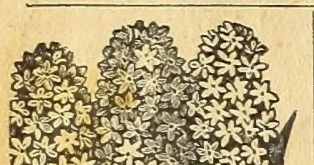

II $T$ is my desire to have all my fied with whatever they may buy from me. The care and culture of flowers is a fascinati.ng pursuit, yet many persons abandon it because of their lack of success. It is not a difficult matter to have flowers that will grow and bloom to perfection, though, in order to do so, it is necessary to give your plants carefui attention in certain respects.

There is published in this city a monthly magazine entirely devoted to home floriculture. It is called HOW TO GROW FLOWERS, and the name tells exactly what the publication is. It supplies, in compact form, plain and practical information about flower-growing, in all its phases. A careful reading of this magazine will enable any one to have success with flowers. Would you know what to do, when to do, and

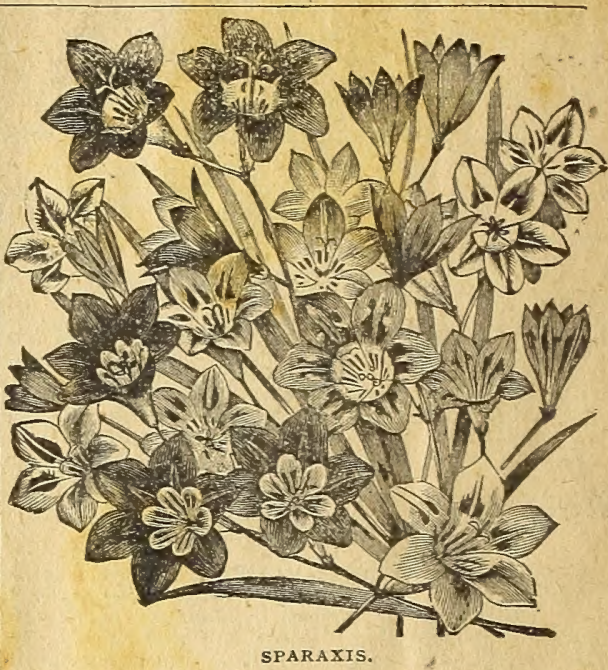
how to do it, so that your plants may be depended upon to give you a full crcp of fragrance and beauty? Then read and heed the teachings of this great magazine. Each number contains thirty-six large pages, printed on fine book paper, and illustrated with half-tone engravings. The articles published are written by persons who know from experience exactly how to treat flowers. The illustrations are made from photographs, which show flowers as they actually are.

HOW TO GROW FLOWERS is the only magazine of its kind in the whole world. You need it for your own satisfaction, and I am anxious for you to have it, in order that you may succeed with the plants and bulbs which you buy of me. The subscription price of HOW TO GROW FLOWERS is fifty cents a year. By special arrangement with the publishers of the magazine, I am able to make the following

\section{Most Remarkably Liberal Offer.}

Send me fifty cents for one year's subscription for HOW TO GROW FLOWERS. In return you will receive the magazine regularly for twelve months, and also, absolutely free of all charge, a magnificent collection of six choice Winter and Spring-blooming bulbs, as follows :

Two Choice Hyacinths, different colors. Every one L Six Tulips, assorted colors, with massive flowers of who grows Spring-blooming bulbs wants at least a few Hyacinths, and these bulbs may be depended upon to give satisfaction.

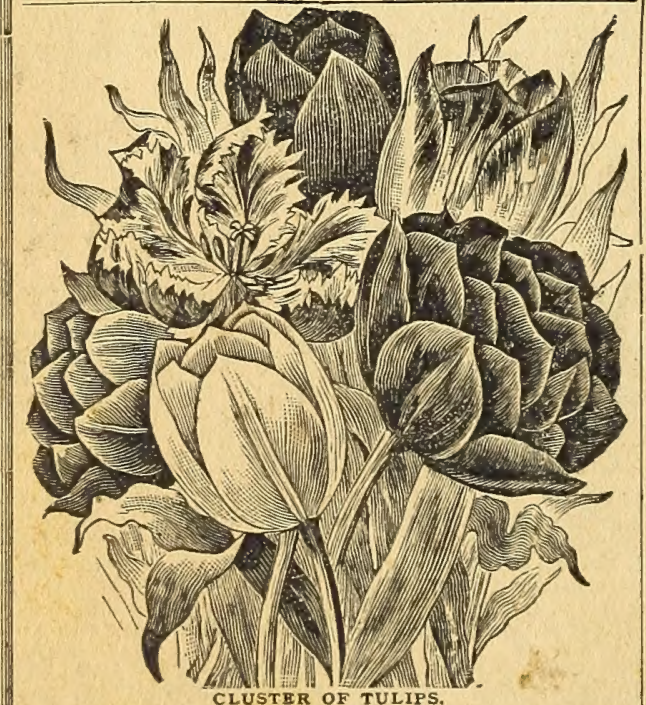

Six Tulips, assorted

Six Narcissus, mixed varieties, one bulb each of the best new kinds. Narcissus are of very easy culture.

Four Scilla Siberica, one of the loveliest of Spring flowers, deep blue in color.

Six Bermuda Buttercup oxalis, without an equal as a inter-flowering pot plant. Rare and choice.

Six Spanish Iris, an ëntirely hardy flower of wide popularity. Six Selected Grape Hyacinths, a beautiful little flower, ofen called "The Blue Lily of the Valley."

Six Crocus, the first flower of Spring.

Six Ixias, assorted kinds. A beautiful flower of brilliant col-

Six Sparaxis, fine for pot culture. Wide variety in colors.

Six Tritilea Unifolia, splendid for pots, will remain in bloom for several months.

For fuller description of the bulbs in this collection, see other pages of thes catalopue. Finll cultural directions will appear fram time to time in HOW TO GROW FLOWERS.

Remember that for only fifty cents I will send you, postage prepaid, the above-described sixty bulbs and HOW TO GROW FLOWERS one year. No matter how large or how small may be your order this season, you should include this with it. Call the attention of youx neighbors to the great bargain I offer, and many of them will be pleased to order with you. In ordering, state that you want to take advantage of combination offer of HOW TO GROW FLOWERS one year and "Collection No. 350." Always address

MISS ELLA V. BAINES, The Woman Florist, SPRINGFIELD, OHIO. 